\title{
A central cysteine residue is essential for the thermal stability and function of SUMO-1 protein and SUMO-1 peptide protein conjugates
}

\author{
Hervé Drobecq, ${ }^{\mathrm{a}}$ Emmanuelle Boll, ${ }^{\mathrm{a}}$ Magalie Sénéchal, ${ }^{\mathrm{a}}$ Rémi Desmet, ${ }^{\mathrm{a}}$ Jean-Michel Saliou, ${ }^{\mathrm{b}}$ Jean-Jacques \\ Lacapère, ${ }^{\mathrm{c}}$ Alexandra Mougel, ${ }^{\mathrm{a}}$ Jérôme Vicogne, ${ }^{\mathrm{a} *}$ Oleg Melnyk ${ }^{\mathrm{a}} *$

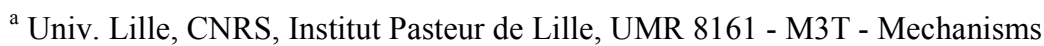 \\ of Tumorigenesis and Target Therapies, F-59000 Lille, France \\ ${ }^{\mathrm{b}}$ Univ. Lille, CNRS, Inserm, CHU Lille, Institut Pasteur de Lille, U1019 - UMR 8204, F-59000 Lille, France. \\ ${ }^{\mathrm{c}}$ Sorbonne Universités, UPMC Univ Paris 06, École Normale Supérieure, PSL Research University, CNRS \\ UMR 7203 LBM, F-75005, Paris, France.
}

Corresponding authors:

Dr Oleg Melnyk, E-mail : oleg.melnyk@ibl.cnrs.fr

Web site: http://olegmelnyk.cnrs.fr

Phone: +33 (0)320871214

and Dr Jérôme Vicogne, E-mail : jerome.vicogne@ibl.cnrs.fr

Phone: +33 (0)3 20871249

Cancer Chemistry \& Biology team

Cent Nat de la Recherche Scientifique (CNRS)

Institut de Biologie de Lille

1 rue du Pr Calmette, CS 50447, 59021 Lille cedex, France. 
Table of content

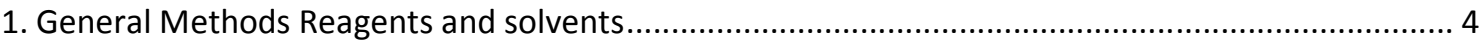

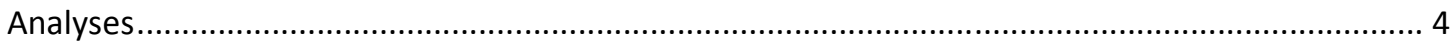

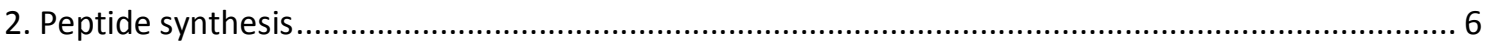

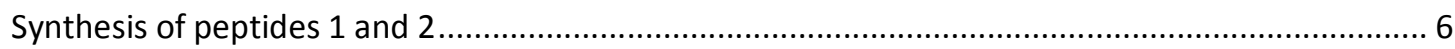

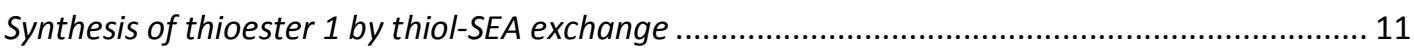

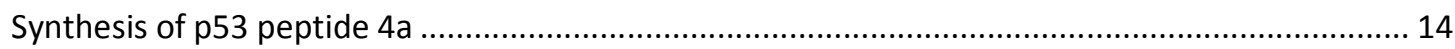

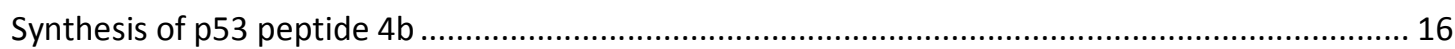

Synthesis of p53 SUMO-1 peptide protein conjugates .......................................................... 19

One-pot synthesis of p53 SUMO-1 peptide conjugate 5 a..................................................... 19

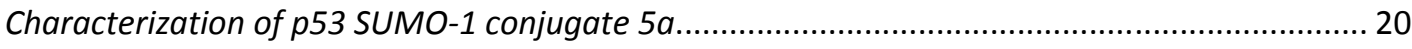

MALDI-TOF in source fragmentation of p53 SUMO-1 conjugate 5a. Proof of structure.............. 23

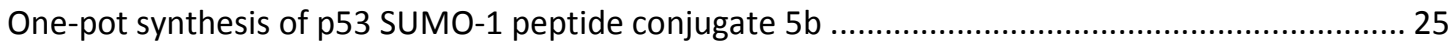

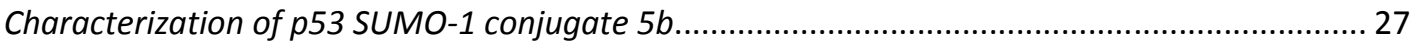

MALDI-TOF in source fragmentation of p53 SUMO-1 conjugate 5b. Proof of structure .............. 30

Synthesis of conjugate $6 a$ by selective desulfurization of conjugate 5 a...................................... 32

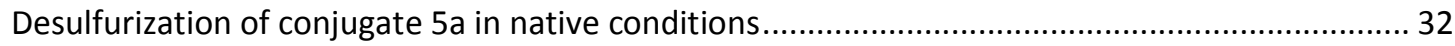

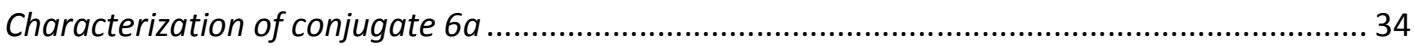

MALDI-TOF in source fragmentation of p53 SUMO-1 conjugate 6a. Proof of structure ............... 36

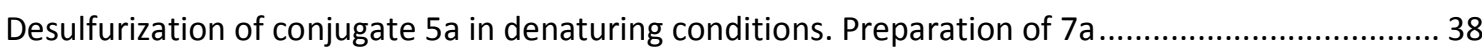

Alkylation of $5 \mathrm{a}, 6 \mathrm{a}$ and $7 \mathrm{a}$ with iodoacetamide, enzymatic cleavage and analysis of the peptide

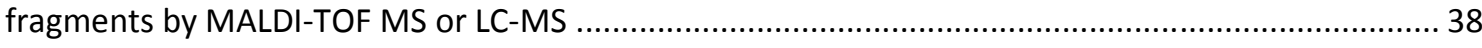

Synthesis of conjugate $6 \mathrm{~b}$ by selective desulfurization of conjugate $5 \mathrm{~b}$..................................... 41

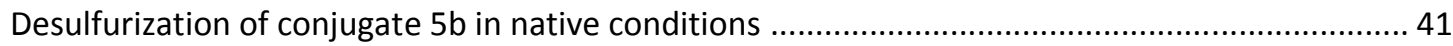

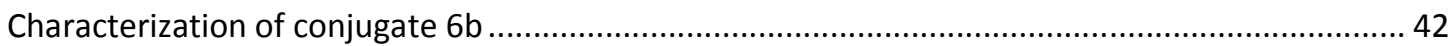

MALDI-TOF in source fragmentation of p53 SUMO-1 conjugate 6b. Proof of structure ................. 44

Alkylation of conjugates $5 \mathrm{~b}$ and $6 \mathrm{~b}$ with iodoacetamide, enzymatic cleavage and analysis of the peptide fragments by MALDI-TOF MS or LC-MS .................................................................... 46

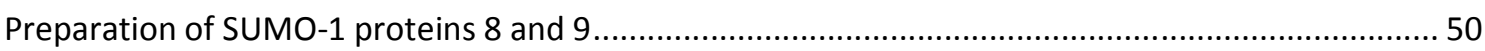

MALDI-TOF characterization of commercial hSUMO-1 (mixed disulfide with $\beta$-mercaptoethanol) 50

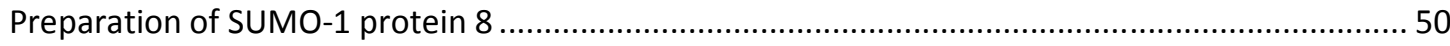

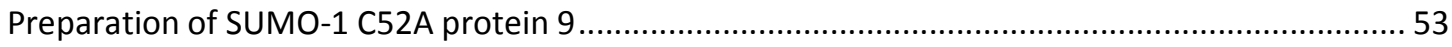

Structure and functionality of p53 SUMO-1 conjugates ........................................................5 55 


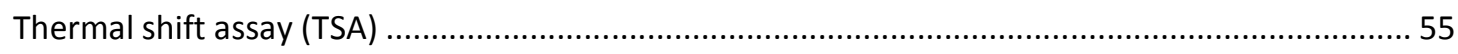

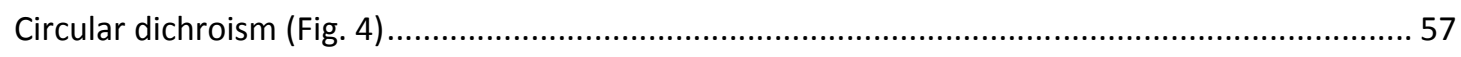

Cleavage of the p53 SUMO-1 conjugates $6 \mathrm{~b}$ and 7b by Ulp1 enzyme .....................................58

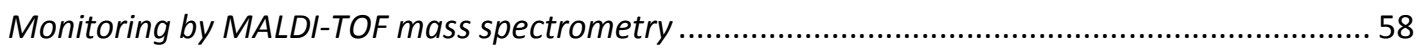

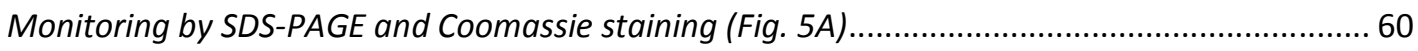

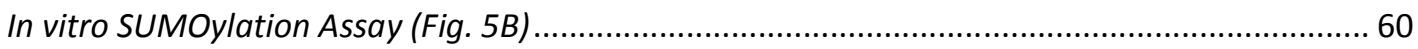

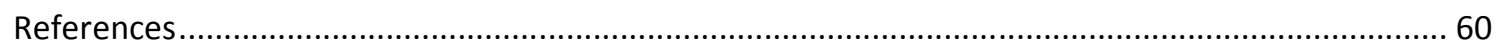




\section{General Methods}

Reagents and solvents

$N$-[(dimethylamino)-1H-1,2,3-triazolo-[4,5-b]pyridin-1-ylmethylene]- $N$-methylmethanaminium hexafluorophosphate $\mathrm{N}$-oxide (HATU) and $\mathrm{N} \alpha-\mathrm{Fmoc}$ protected amino acids were obtained from Iris Biotech $\mathrm{GmbH}$. Side-chain protecting groups used for the amino acids were Fmoc-Ala-OH, Fmoc$\mathrm{Arg}(\mathrm{Pbf})-\mathrm{OH}, \mathrm{Fmoc}-\mathrm{Asn}(\mathrm{Trt})-\mathrm{OH}, \mathrm{Fmoc}-\mathrm{Asp}(\mathrm{OtBu})-\mathrm{OH}, \mathrm{Fmoc}-\mathrm{Gln}(\mathrm{Trt})-\mathrm{OH}$, Fmoc-Glu(OtBu)-OH, FmocGly-OH, Fmoc-His(Trt)-OH, Fmoc-lle-OH, Fmoc-Leu-OH, Fmoc-Lys(Boc)-OH, Fmoc-Met-OH, Fmoc-Phe$\mathrm{OH}$, Fmoc-Pro-OH, Fmoc-Ser(tBu)-OH, Fmoc-Thr(tBu)-OH, Fmoc-Tyr(tBu)-OH, Fmoc-Val-OH, Fmoc$\mathrm{Cys}(\mathrm{StBu})-\mathrm{OH}$ or Fmoc-Cys(Trt)-OH. Synthesis of bis(2-sulfanylethyl)aminotrityl polystyrene (SEA PS) resin was carried out as described elsewhere.(1) Rink-PEG-PS resin (NovaSyn TGR) was obtained from Novabiochem. 4-mercaptophenylacetic acid (MPAA), 3-mercaptopropionic acid (MPA), tris(2carboxyethyl)phosphine hydrochloride (TCEP) were purchased from Sigma-Aldrich. All other reagents were purchased from Acros Organics or Merck and were of the purest grade available.

Peptide synthesis grade $\mathrm{N}, \mathrm{N}$-dimethylformamide (DMF), dichloromethane $\left(\mathrm{CH}_{2} \mathrm{Cl}_{2}\right)$, diethylether $\left(\mathrm{Et}_{2} \mathrm{O}\right)$, acetonitrile $\left(\mathrm{CH}_{3} \mathrm{CN}\right)$, heptane, LC-MS-grade acetonitrile $\left(\mathrm{CH}_{3} \mathrm{CN}, 0.1 \%\right.$ TFA and $\mathrm{CH}_{3} \mathrm{CN}, 0.1 \%$ formic acid), LC-MS-grade water $\left(\mathrm{H}_{2} \mathrm{O}, 0.1 \%\right.$ TFA and $\mathrm{H}_{2} \mathrm{O}, 0.1 \%$ formic acid), $\mathrm{N}, \mathrm{N}$ diisopropylethylamine (DIEA), acetic anhydride $\left(\mathrm{Ac}_{2} \mathrm{O}\right)$ were purchased from Biosolve and FisherChemical. Trifluoroacetic acid (TFA) was obtained from Biosolve. Water was purified with a Milli-Q Ultra Pure Water Purification System.

\section{Analyses}

The reactions were monitored by analytical LC-MS (Waters 2695 LC/ZQ 2000 quadripole) on an reverse phase column. The column, eluent system and gradient used are indicated in the figure legends. The column eluate was monitored by UV at $215 \mathrm{~nm}$ and by evaporative light scattering (ELS, Waters 2424). The peptide masses were measured by on-line LC-MS: Ionization mode: ES+, $\mathrm{m} / \mathrm{z}$ range 350-2040, capillary voltage $3 \mathrm{kV}$, cone voltage $30 \mathrm{~V}$, extractor voltage $3 \mathrm{~V}$, RF lens $0.2 \mathrm{~V}$, source temperature $120^{\circ} \mathrm{C}$, dessolvation temperature $350^{\circ} \mathrm{C}$. Samples were prepared using $10 \mu \mathrm{L}$ aliquots of the reaction mixtures. The aliquots were quenched by adding $90 \mu \mathrm{L}$ of $1 \%$ aqueous TFA, extracted with $\mathrm{Et}_{2} \mathrm{O}$ to remove MPAA or MPA before analysis.

MALDI-TOF mass spectra were recorded with a BrukerAutoflex Speed mass spectrometer. The matrix used for the analysis is indicated in the figure legends.

\section{High resolution LC-MS analysis}

Reverse-phase high performance liquid chromatography was performed using an UltiMate ${ }^{\mathrm{TM}} 3000$ RSLC LC system (Thermo Scientific). Samples ( $0.4 \mu \mathrm{g}$ each) were injected onto a XBridge ${ }^{\mathrm{TM}}$ BEH 300 C18 column ( $3.5 \mu \mathrm{m}$ particle size, $10 \times 150 \mathrm{~mm}$, Waters) set at $50^{\circ} \mathrm{C}$. Elution was performed at a flow rate of $50 \mu \mathrm{L} / \mathrm{min}$ using $0.1 \%$ aqueous formic acid (FA) for mobile phase $A$ and a gradient of acetonitrile containing $0.1 \%$ FA for mobile phase B which raised from $2 \%$ to $80 \%$ in 15 min.

The liquid chromatography flow was split and infused at $500 \mathrm{nl} / \mathrm{min}$ into a Xevo G2-XS Tof mass spectrometer (Waters) by a TriVersa Nanomate robot (Advion). 
The mass spectrometer was run in sensitivity positive ion mode with source parameters as follows: capillary voltage, $3.00 \mathrm{kV}$; sampling cone voltage, $30.0 \mathrm{~V}$; source offset $80 \mathrm{~V}$; source temperature, $80^{\circ} \mathrm{C}$. Acquisitions were performed on the mass range $\mathrm{m} / \mathrm{z} 400-2000$ with a $1 \mathrm{~s}$ scan time. Calibration was performed using the singly charged ions produced by a solution of sodium iodide $(2 \mu \mathrm{g} / \mu \mathrm{L})$ and cesium iodide $(50 \mathrm{ng} / \mu \mathrm{L})$ in 2-propanol/ water (1/1).

Data analysis was performed with MassLynx 4.1 (Waters). The protein peak was deconvoluted by the Masslynx function Transform. 


\section{Peptide synthesis}

\section{Synthesis of peptides 1 and 2}

The preparation of SUMO-1 (2-51)-SEA ${ }^{\text {off }}$, i.e. the precursor of thioester peptide 1, and of Cys(StBu)SUMO-1 (52-97)-SEA ${ }^{\text {off }}$ peptide 2 have been described in detail elsewhere.(2, 3) However, the protocol for their synthesis and the yield have been significantly improved. The novel protocols are therefore described below.

The sequence for SUMO-1 (2-51) is: SDQEAKPSTE DLGDKKEGEY IKLKVIGQDS SEIHFKVKMT THLKKLKESY

The sequence for SUMO-1 (52-97) is: C(StBu)QRQGVPMNS LRFLFEGQRI ADNHTPKELG MEEEDVIEVY QEQTGG

The first amino acid was coupled manually. The rest of the sequence was assembled using an automated Fmoc SPPS synthesizer.

Coupling of the first amino acid residue to the SEA ChemMatrix resin

The preparation the SEA ChemMatrix resin and of has been described in detail elsewhere. $(2,3)$

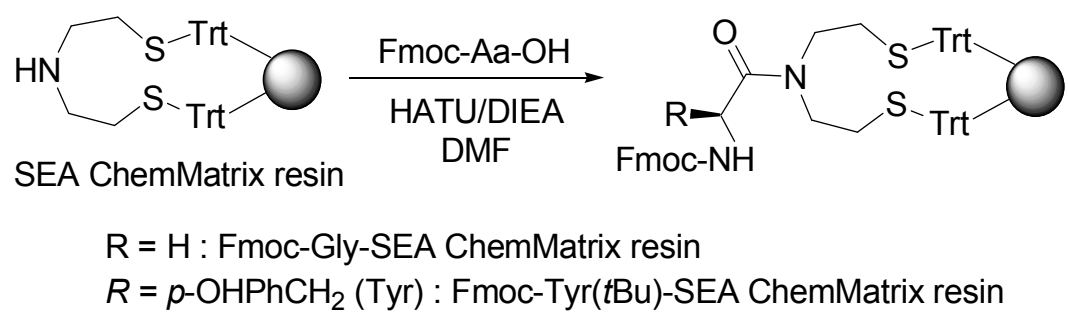

Scheme S1

SEA ChemMatrix resin $(0.15 \mathrm{mmol} / \mathrm{g})(333 \mathrm{mg}, 49.9 \mu \mathrm{mol}$ for SUMO-1 (2-51) and $371 \mathrm{mg}, 55.6 \mu \mathrm{mol}$ for SUMO-1 (52-97)) was conditioned in DMF ( $3 \times 2 \mathrm{~min}, 3 \mathrm{~mL})$ in a manual SPPS glass reactor.

Fmoc-Aa-OH (148 mg for Fmoc-Gly-OH, 0.497 mmol; 230 mg for Fmoc-Tyr $(t B u)-O H, 0.500$ mmol) was dissolved in DMF (1 mL). N-[(dimethylamino)-1H-1,2,3-triazolo-[4,5-b]pyridin-1-ylmethylene]- $N$ methylmethanaminium hexafluorophosphate $N$-oxide (HATU, $190 \mathrm{mg}, 0.499 \mathrm{mmol}$ ) was dissolved in the minimal volume of DMF and added to the amino acid solution. Finally, DIEA (174 $\mu \mathrm{L}, 1.34 \mathrm{mmol}$ ) was added to the above solution to start the activation of the amino acid. This solution was agitated for $1 \mathrm{~min}$ and then added to the resin which was shaken during $1 \mathrm{~h} 30 \mathrm{~min}$ at room temperature. The resin was subsequently washed with DMF $(5 \times 2 \mathrm{~min}, 3 \mathrm{~mL})$. The chloranil assay was negative. The resin was subsequently acetylated with a mixture of acetic anhydride/DIEA/DMF : 10/5/85 by vol ( $2 \times$ $3 \mathrm{~mL}, 2 \mathrm{~min}$ and then $20 \mathrm{~min}$ ) before being washed successively with DMF ( $3 \times 2 \mathrm{~min}, 3 \mathrm{~mL}), \mathrm{CH}_{2} \mathrm{Cl}_{2}$ $(3 \times 2 \mathrm{~min}, 3 \mathrm{~mL})$ and diethylether $(3 \times 2 \mathrm{~min}, 3 \mathrm{~mL})$. The resin was then dried in vacuo during $\sim 3 \mathrm{~h}$. 
The loading of the resin was determined by UV quantification at $290 \mathrm{~nm}$ of the dibenzofulvenepiperidine adduct formed by treating aliquots of the resin with piperidine ( $20 \%$ by vol in DMF). We found $0.14 \mathrm{mmmol} / \mathrm{g}$ for Fmoc-Gly-SEA ChemMatrix resin and $0.157 \mathrm{mmol} / \mathrm{g}$ for Fmoc-Tyr(tBu)-SEA ChemMatrix resin.

\section{Automated solid phase peptide synthesis}

The peptide elongation step was performed using an automated column peptide synthesizer using standard Fmoc-SPPS protocols ( $0.1 \mathrm{mmol}$ scale). The amino acids (10 equiv) were activated using HATU (10 equiv)/DIEA (20 equiv) in DMF. Each amino acid was coupled twice. The peptidyl resin was acetylated with $\mathrm{Ac}_{2} \mathrm{O} / \mathrm{DIEA}$ in DMF after each double coupling.

\section{Deprotection and cleavage step}

The peptidyl resins $(0.1 \mathrm{mmol}$ scale) were deprotected and cleaved in a mixture of TFA/triisopropylsilane (TIS)/dimethylsulfide (DMS)/thioanisole/ $\mathrm{H}_{2} \mathrm{O}: 90 / 2.5 / 2.5 / 2.5 / 2.5$ by vol (10 $\mathrm{mL}$ ) during $1 \mathrm{~h} 30 \mathrm{~min}$ (3 times) for SUMO-1 (2-51), and in a mixture of TFA/triisopropylsilane (TIS)/dimethylsulfide (DMS)/thioanisole/ $\mathrm{H}_{2} \mathrm{O} /$ thiophenol : $82.5 / 2.5 / 5 / 2.5 / 2.5 / 2.5 / 2.5$ by vol $(10 \mathrm{~mL})$ during $1 \mathrm{~h} 30 \mathrm{~min}$ (3 times) for SUMO-1 (52-97). The crude peptides were precipitated in an ice-cold mixture of $\mathrm{Et}_{2} \mathrm{O} / \mathrm{n}$-heptane : $1 / 1$ by vol to give $463 \mathrm{mg}$ (63\% crude) of SUMO-1 (2-51)-SEA ${ }^{\text {on }}$ peptide and $164 \mathrm{mg}$ (53\% crude) of SUMO-1 (52-97)-SEA ${ }^{\text {on }}$ peptide.

\section{Oxidation and purification of SEA $A^{\text {off }}$ peptide segments}

The crude SEA ${ }^{\text {on }}$ peptide segments $(\sim 9 \mu \mathrm{mol})$ were dissolved in $\mathrm{AcOH} / \mathrm{H}_{2} \mathrm{O}: 1 / 4$ by vol (final peptide concentration $\sim 0.9 \mathrm{mM}$ ). lodine solution (200 mM in DMSO) was added in dropwise until the appearance of a yellow color. After $30 \mathrm{~s}$, dithiothreitol (DTT, $65 \mathrm{mM}$ in water) was added dropwise until the disappearance of the yellow color to quench the excess of iodine. Once DTT was added, the mixture was immediately purified by reversed-phase HPLC to give the corresponding SEA ${ }^{\text {off }}$ peptide segments.

Semi-preparative HPLC conditions for SEA ${ }^{\text {off }}$ peptide segments: C3 Zorbax column ( $5 \mu \mathrm{m}, 300 \AA$, $9.4 \times$ $250 \mathrm{~mm}$, Agilent), eluent $A$ water containing $0.1 \%$ of TFA, eluent $B \mathrm{CH}_{3} \mathrm{CN} /$ water : $4 / 1$ by vol containing $0.1 \%$ of TFA, gradient: $0-20 \% \mathrm{~B}$ in $5 \mathrm{~min}$, then $20-50 \% \mathrm{~B}$ in $60 \mathrm{~min}, 65{ }^{\circ} \mathrm{C}$, flow rate 6 $\mathrm{mL} / \mathrm{min}$, UV detection at $215 \mathrm{~nm}$.

Yield for SUMO-1 (2-51)-SEA ${ }^{\text {off }}: 50$ mg of crude product furnished (13.6 mg, 13.6\%) of SUMO-1 (2-51)SEA ${ }^{\text {off }}$ peptide.

Yield for SUMO-1 (52-97)-SEA ${ }^{\text {off }}$ 2: $164.01 \mathrm{mg}$ of crude product furnished (43.8 mg, 14\%) of SUMO-1 (52-97)-SEA ${ }^{\text {off }}$ peptide 2. 


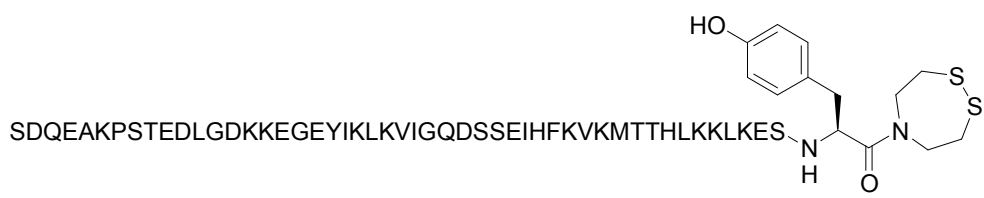

SUMO-1 (2-51)-SEA ${ }^{\text {off }}$

A)

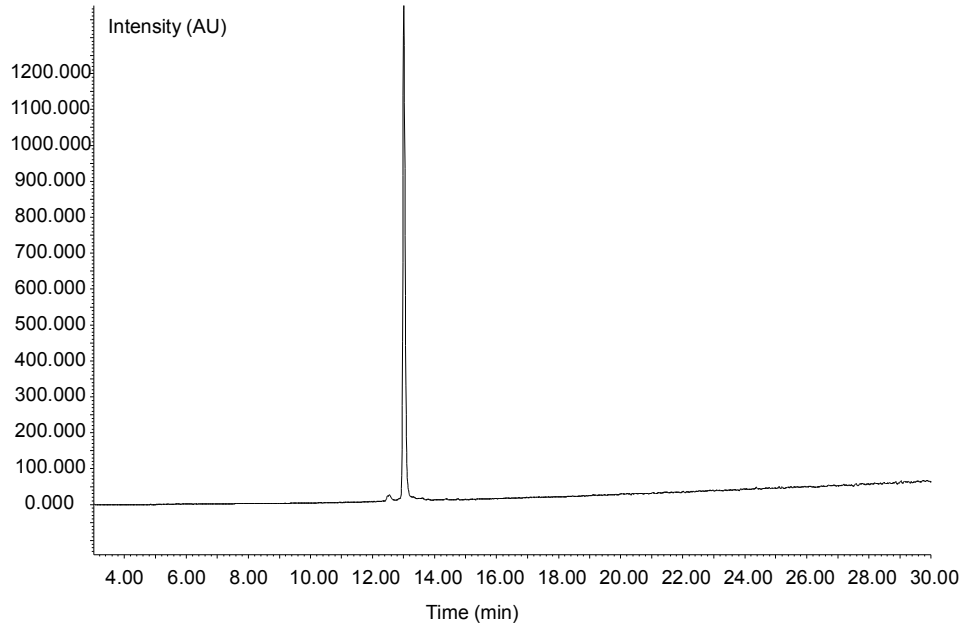

B)

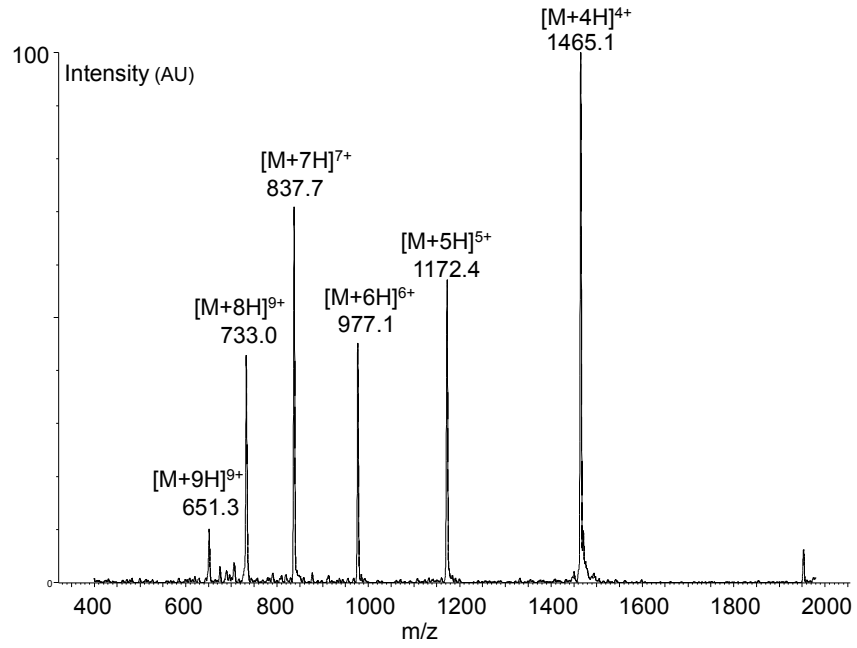


C)

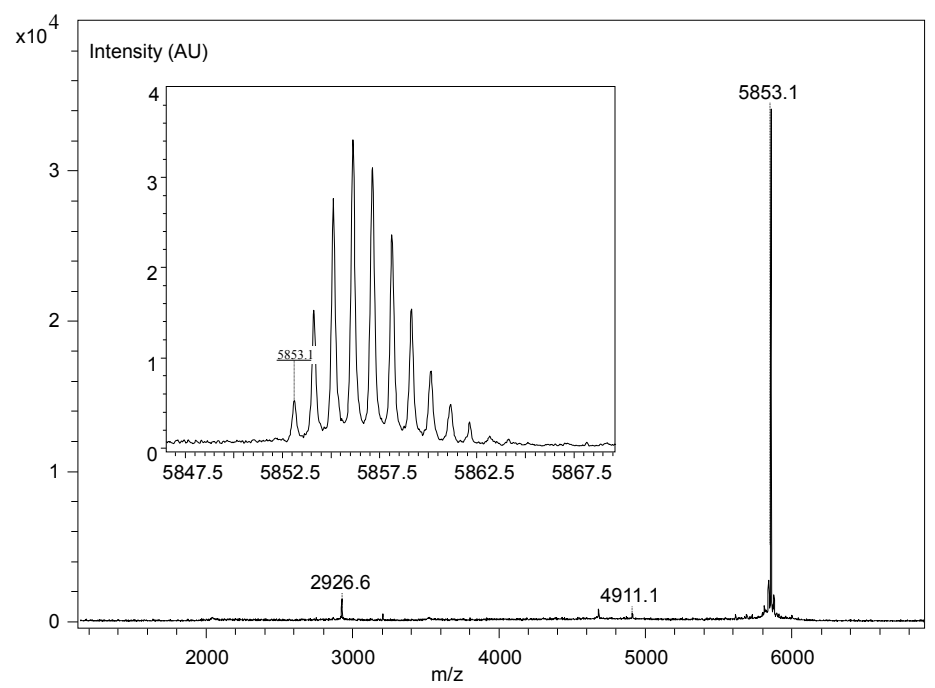

Figure S1. Analysis of SUMO-1 (2-51)-SEA ${ }^{\text {off }}$ peptide. LC-MS analysis XBridge BEH300 C18 $3.5 \mu \mathrm{m}$ $4.6 \mathrm{~mm} \times 150 \mathrm{~mm}, 50{ }^{\circ} \mathrm{C}$. Flow $1 \mathrm{~mL} / \mathrm{min}$, eluent $A 0.1 \%$ trifluoroacetic acid in water, eluent $B 0.1 \%$ trifluoroacetic acid in $80 \%$ aqueous acetonitrile. Gradient from $0 \%$ buffer B to $100 \%$ buffer B in 30 min. A) HPLC trace (light scattering detection) B) MS trace Calculated for M (average mass) 5855.75, observed 5855.88 after deconvolution. C) MALDI-TOF analysis of SUMO-1 (2-51)-SEA ${ }^{\text {off }}$ peptide. Matrix: Sinapinic acid Calculated for $[\mathrm{M}+\mathrm{H}]^{+}$(monoisotopic mass) 5852.9, observed 5853.1 


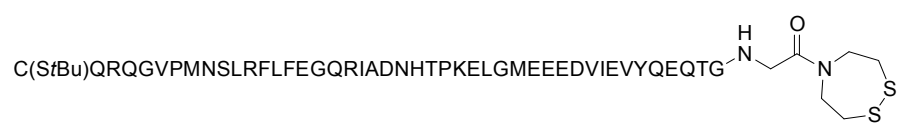

SUMO-1 (52-97)-SEA ${ }^{\text {off }} 2$

A)

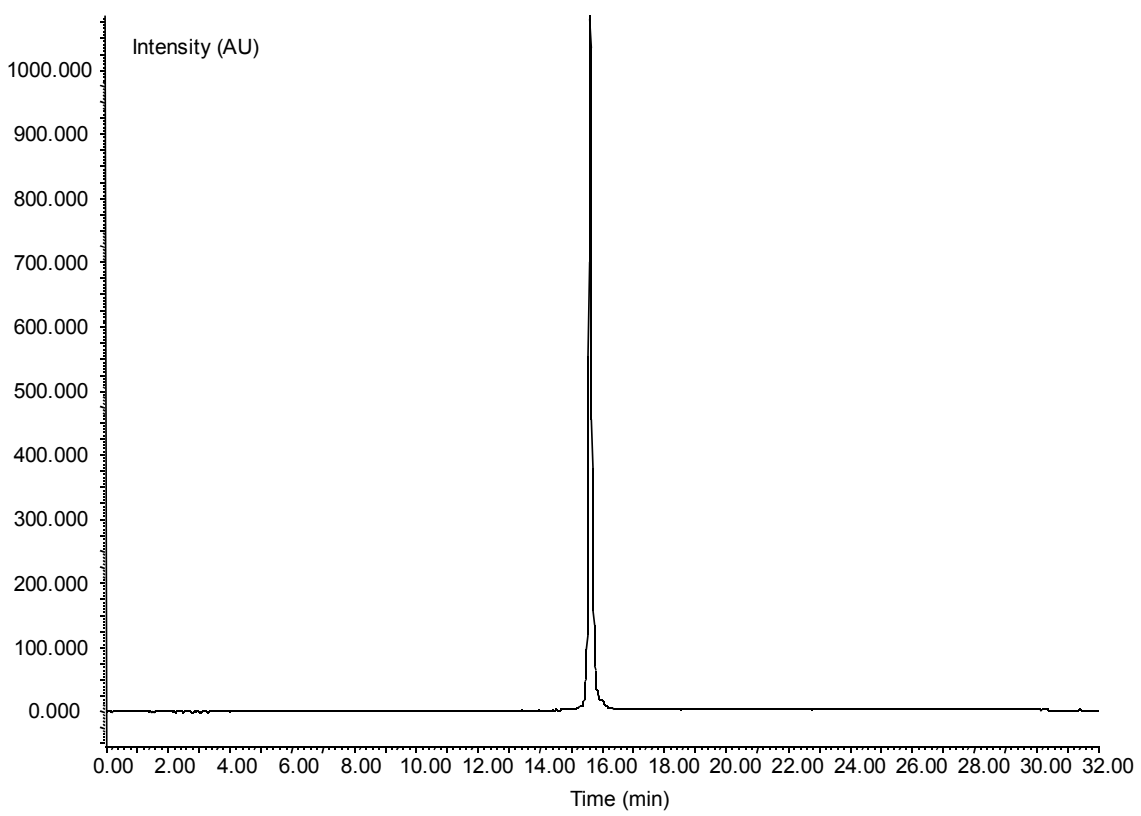

B)

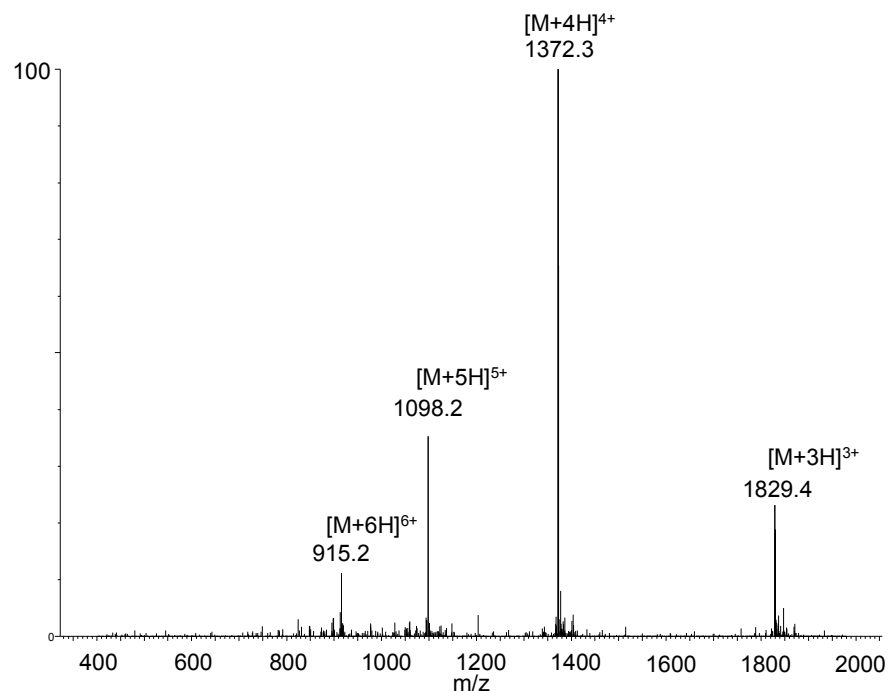


C)

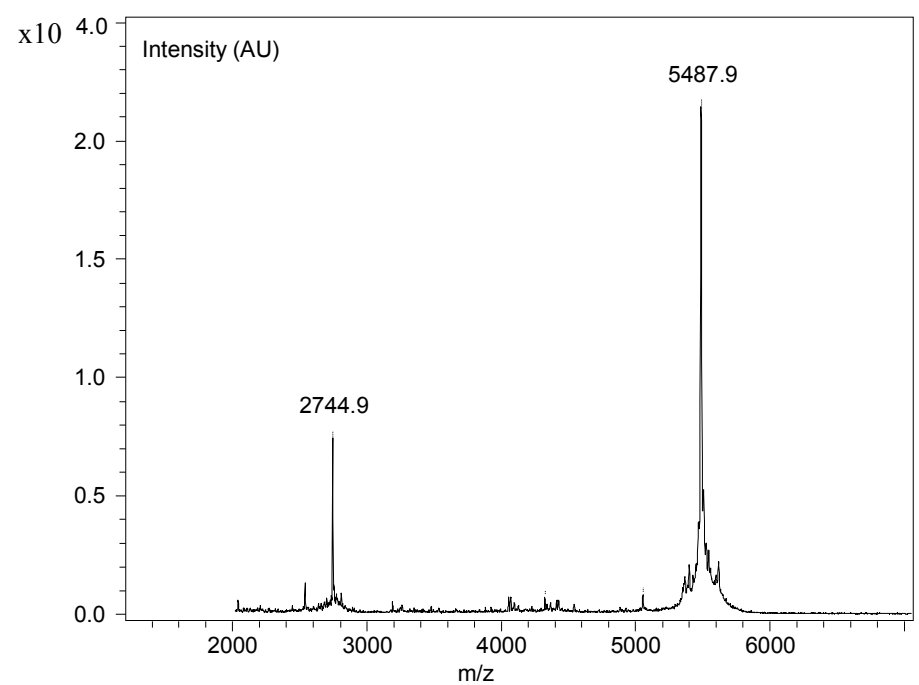

Figure S2. Analysis of SEA ${ }^{\text {off }}$ peptide segment 2. LC-MS analysis XBridge BEH300 C18 $3.5 \mu \mathrm{m} \mathrm{4.6mm} \times$ $150 \mathrm{~mm}, 50{ }^{\circ} \mathrm{C}$. Flow $1 \mathrm{~mL} / \mathrm{min}$, eluent $A \quad 0.1 \%$ trifluoroacetic acid in water, eluent $B 0.1 \%$ trifluoroacetic acid in $80 \%$ aqueous acetonitrile. Gradient from $0 \%$ buffer B to $100 \%$ buffer B in 30 min. A) HPLC trace (light scattering detection) B) MS trace A) HPLC trace (light scattering detection). B) MS trace for $S E A^{\text {off }}$ peptide segment 2. Calculated for $[\mathrm{M}+\mathrm{H}]^{+}$(average mass) 5487.25, observed 5487.47 after deconvolution. C) MALDI-TOF analysis of SEA ${ }^{\text {off }}$ peptide segment 2. Matrix: Sinapinic acid Calculated for $[\mathrm{M}+\mathrm{H}]^{+}$(average mass) 5487.25, observed 5487.9.

\section{Synthesis of thioester 1 by thiol-SEA exchange}

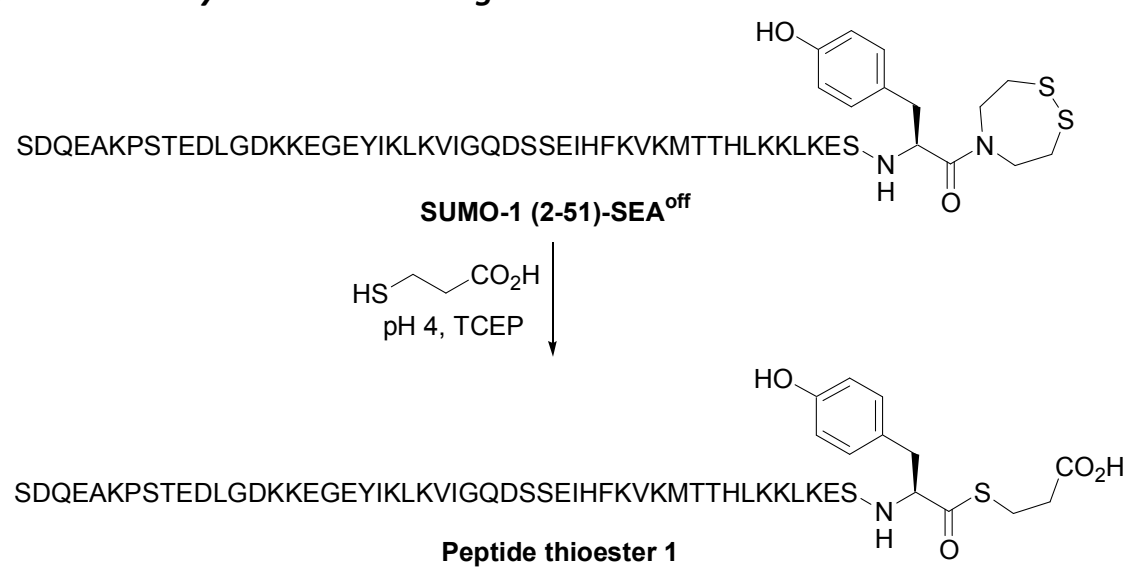

Scheme S2. SEA-thiol exchange reaction for the preparation of peptide thioester $\mathbf{1 .}$

The reaction was carried out under nitrogen atmosphere. Tris(2-carboxylethyl)phosphine hydrochloride (TCEP. HCl, $346 \mathrm{mg}, 80.0 \mathrm{mmol}$ ) was dissolved in $0.2 \mathrm{M} \mathrm{pH} 7.3$ sodium phosphate 
buffer (15.1 mL). SUMO-1 (2-51)-SEA ${ }^{\text {off }}$ peptide $(36.9 \mathrm{mg}, 5.03 \mu \mathrm{mol})$ was dissolved in the above solution $(15.1 \mathrm{~mL})$. Then, 3-mercaptopropionic acid (MPA, $755 \mu \mathrm{L}$ ) was added and the $\mathrm{pH}$ of the reaction mixture was adjusted to 4.0 by addition of $6 \mathrm{M} \mathrm{NaOH}$. The reaction was agitated at $37^{\circ} \mathrm{C}$ for $48 \mathrm{~h}$ and then acidified with $10 \%$ aqueous TFA $(510 \mu \mathrm{L})$. The mixture was extracted with diethylether $(3 \times 20 \mathrm{~mL}$ ) to remove the excess of MPA and immediately purified by RP-HPLC using a C18 Xbridge BEH300 prep column $(10 \times 250 \mathrm{~mm}, 5 \mu \mathrm{m})$ to give $14.98 \mathrm{mg}(40 \%)$ of peptide thioester 1.

Gradient used for the HPLC purification: eluent $A$ water containing $0.1 \%$ of TFA, eluent $B$ $\mathrm{CH}_{3} \mathrm{CN} /$ water : $4 / 1$ by vol containing $0.1 \%$ of TFA, gradient: $0-25 \%$ B in $5 \mathrm{~min}$, then $25-50 \%$ B in 60 $\mathrm{min}$, flow rate $6 \mathrm{~mL} / \mathrm{min}$, UV detection at $215 \mathrm{~nm}$.

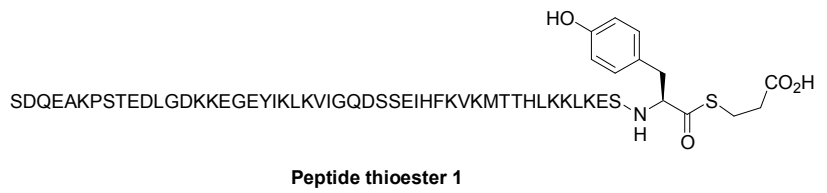

A)

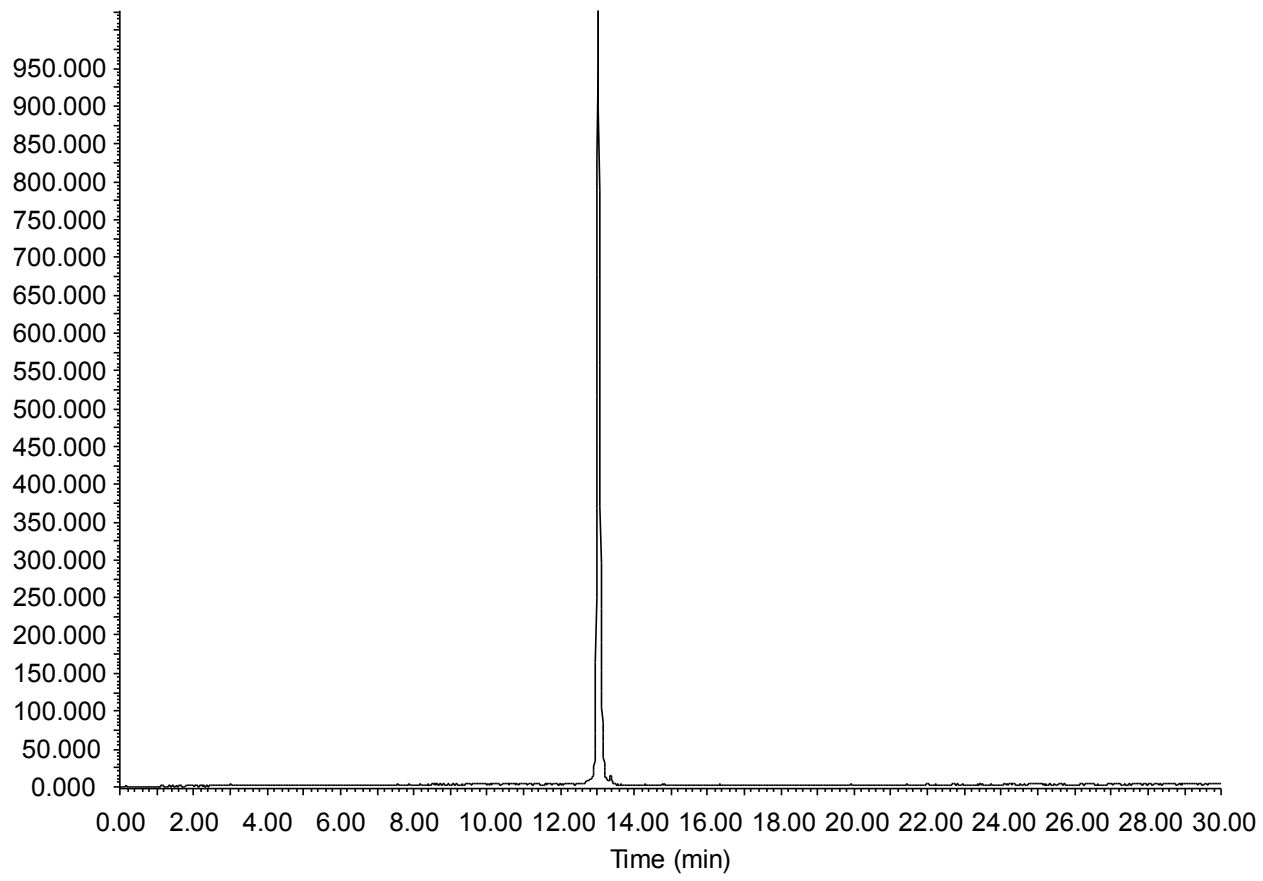


B)

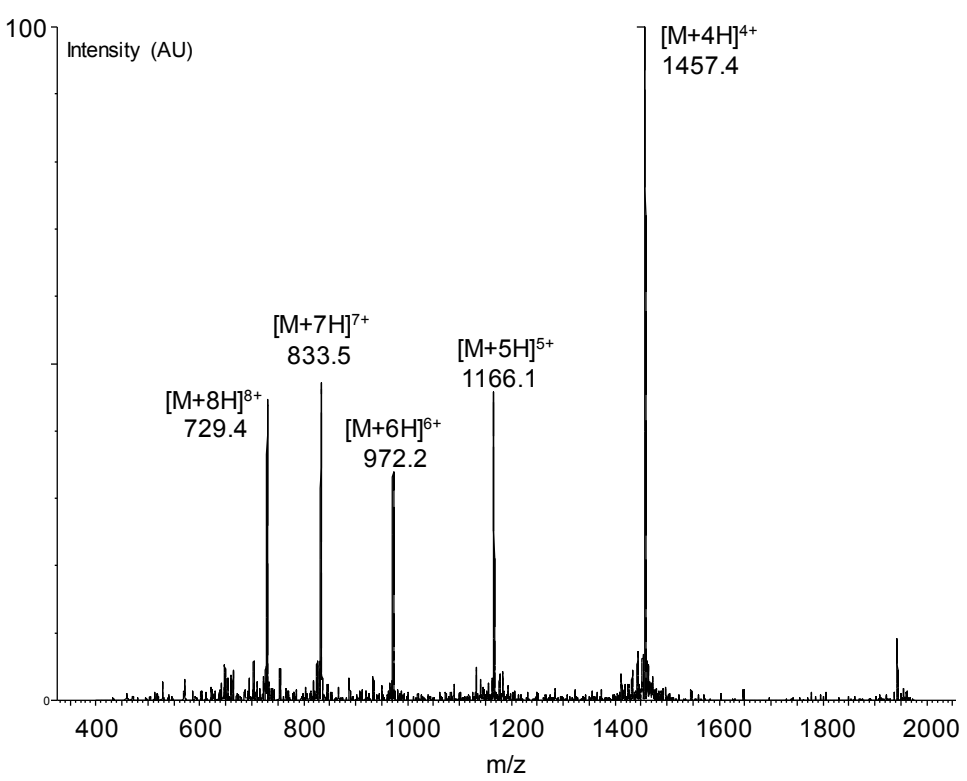

C)

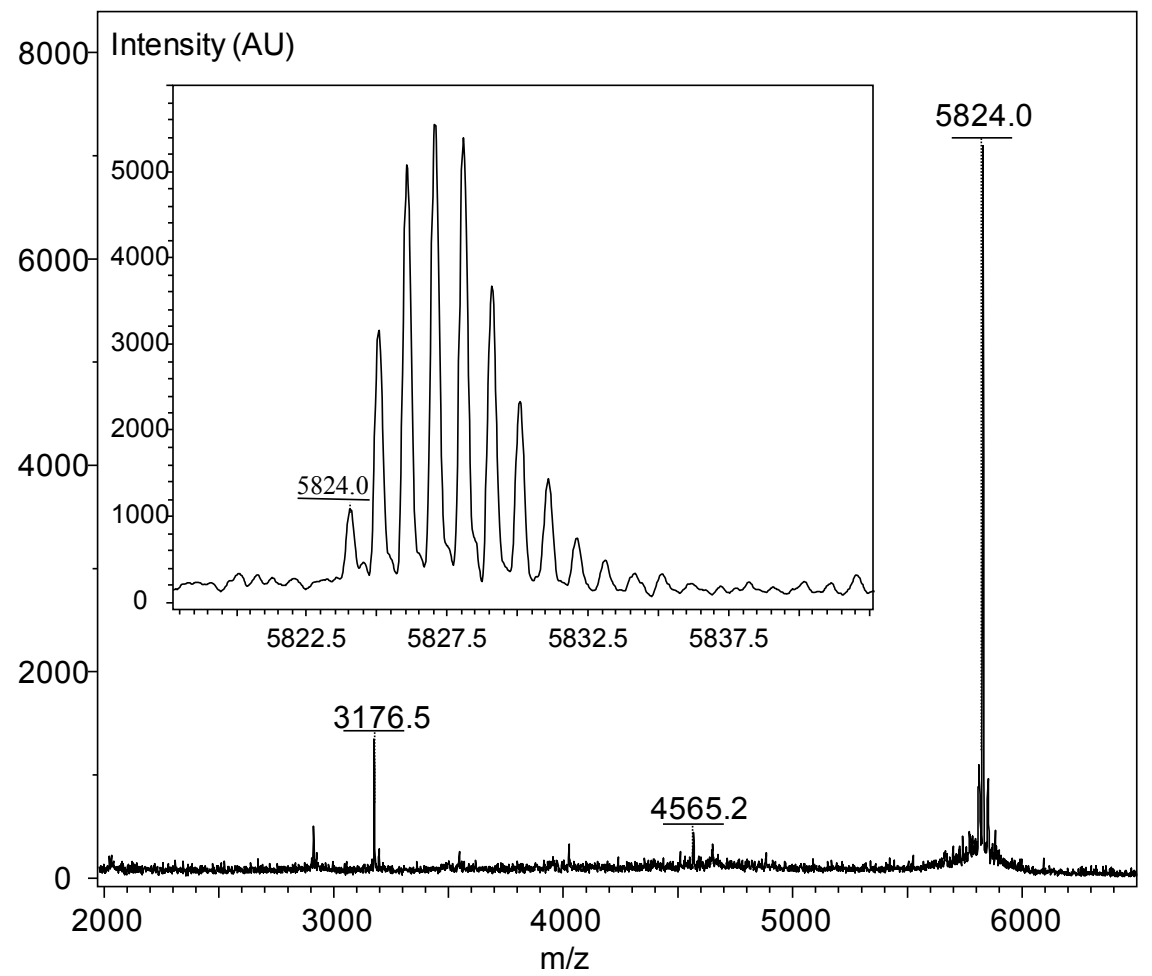

Figure S3. Analysis of peptide thioester 1. LC-MS analysis XBridge BEH300 C18 $3.5 \mu \mathrm{m} 4.6 \mathrm{~mm} \times 150$ $\mathrm{mm}, 50{ }^{\circ} \mathrm{C}$. Flow $1 \mathrm{~mL} / \mathrm{min}$, eluent $\mathrm{A} 0.1 \%$ trifluoroacetic acid in water, eluent $\mathrm{B} 0.1 \%$ trifluoroacetic acid in $80 \%$ aqueous acetonitrile. Gradient from $0 \%$ buffer B to $100 \%$ buffer B in 30 min. A) HPLC 
trace (light scattering detection). A) HPLC trace (light scattering detection) of peptide thioester 1. B) MS trace, calculated for M (average mass) 5826.64, observed 5826.55 after deconvolution. C) MALDITOF analysis of peptide thioester 1. Matrix alpha-cyano-4-hydroxy-cinnamic acid: Calculated for $[\mathrm{M}+\mathrm{H}]^{+}$(monoisotopic mass) 5823.9, observed 5824.0.

\section{Synthesis of $p 53$ peptide $4 a$}

P53 peptide 4a was synthesized using an automated column peptide synthesizer using standard Fmoc-SPPS protocols $(2 \times 0.05 \mathrm{mmol}$, Novasyn TGR resin, $0.25 \mathrm{mmol} / \mathrm{g})$. The amino acids (10 equiv) were activated using HATU (10 equiv)/DIEA (20 equiv) in DMF. Each amino acid was coupled twice. The peptidyl resin was acetylated with Ac2O/DIEA in DMF after each double coupling. Lysine 386 was coupled as the Fmoc-Lys(Mtt)-OH derivative.

The N-terminal Fmoc group was deprotected manually using $20 \%$ piperidine in DMF $(1 \times 1 \mathrm{~min}$ then 1 $\mathrm{x} 10 \mathrm{~min}) .{ }^{1}$ The resin was then treated with (Boc) ${ }_{2} \mathrm{O}(300 \mathrm{mg} ; 1.37 \mathrm{mmol}, 15$ equiv) solubilized in DMF $(5 \mathrm{~mL})$ for $30 \mathrm{~min}$ at $\mathrm{rt}$ to protect the $\mathrm{N}$-terminal amino group. The Mtt group on Lys 386 residue was deprotected selectively by washing the peptidyl resin with $1 \%$ TFA in $\mathrm{CH}_{2} \mathrm{Cl}_{2}(15 \times 2 \mathrm{~min})$. The resin was then neutralized with 5\% DIEA in DMF.

Fmoc-Cys(Trt)-OH (293 mg, 0.500 mmoles), and PyBop (260 mg, 0.499 mmoles) were solubilized in DMF $(5 \mathrm{~mL})$ and added to the peptidyl resin together with DIEA (175 $\mu \mathrm{L}, 1.00 \mathrm{mmole})$. The resin was agitated for $40 \mathrm{~min}$, and then washed with DMF ( $3 \times 2 \mathrm{~min}), \mathrm{CH}_{2} \mathrm{Cl}_{2}(3 \times 2 \mathrm{~min})$, diethyl ether $(2 \times 2$ $\mathrm{min}$ ) and dried in vacuo.

The peptidyl resin was finally deprotected and cleaved in TFA/TIS/EDT/ $\mathrm{H}_{2} \mathrm{O}: 90 / 5 / 2.5 / 2.5$ by vol (10 $\mathrm{mL}$ ) for $2 \mathrm{~h} \mathrm{30}$. The crude peptide was precipitated in ice-cold heptane /diethylether : $1 / 1$ by vol, solubilized in deionized water and lyophilized to yield $210 \mathrm{mg}$ of crude peptide $\mathbf{4 a}$. The peptide was purified directly by HPLC to give $26.02 \mathrm{mg}$ ( $6 \%$ overall) of peptide $4 \mathrm{a}$

Preparative HPLC conditions for peptide 4a: XBridge BEH300 C18 $(5 \mu \mathrm{m}, 300 \AA ̊, 10 \times 250 \mathrm{~mm})$ column, eluent $A$ water containing $0.1 \%$ of TFA, eluent $B \mathrm{CH}_{3} \mathrm{CN} /$ water : $4 / 1$ by vol containing $0.1 \%$ of TFA, gradient: $0-10 \% B$ in $2 \mathrm{~min}$, then $10-25 \% \mathrm{~B}$ in $60 \mathrm{~min}$, flow rate $6 \mathrm{~mL} / \mathrm{min}, 50^{\circ} \mathrm{C}$, UV detection at $215 \mathrm{~nm}$.

\footnotetext{
${ }^{1}$ The N-terminal Fmoc group was partially removed upon standing in the synthesis column overnight.
} 


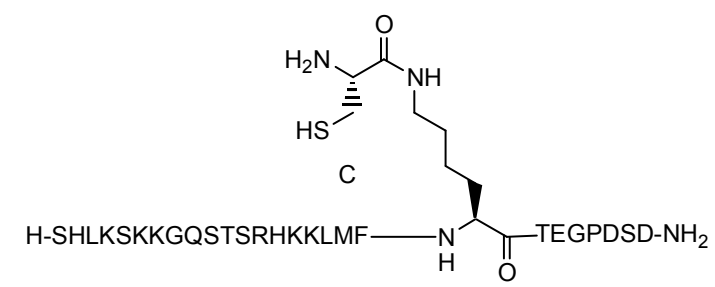

p53 peptide 4a

A)

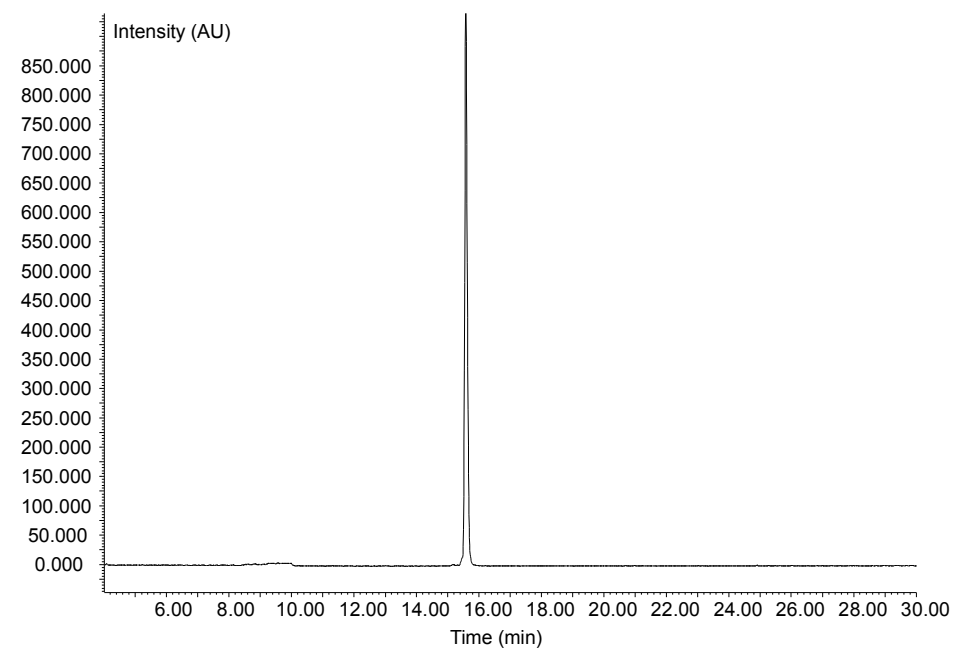

B)

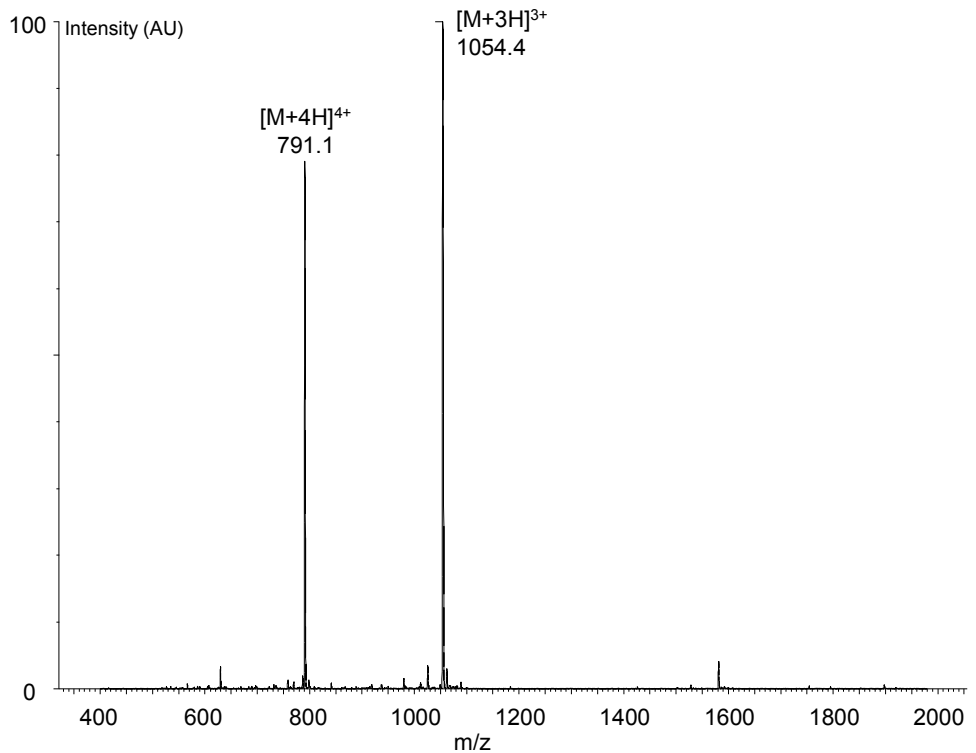


C)

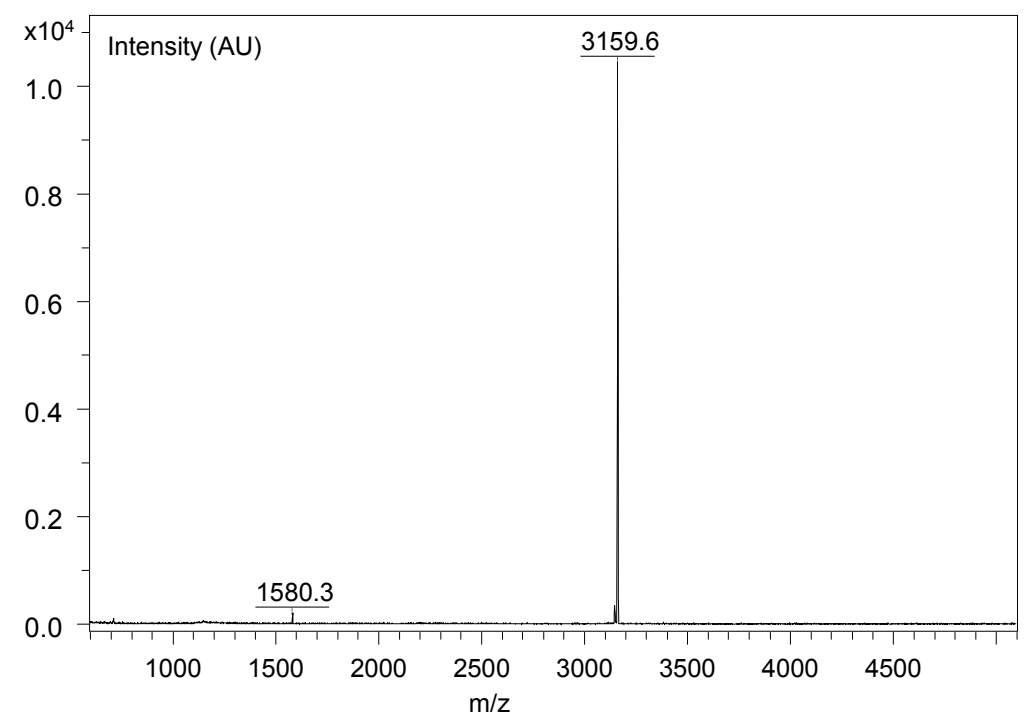

Figure S4. Analysis of peptide 4a. LC-MS analysis XBridge BEH300 C18 $3.5 \mu \mathrm{m} \mathrm{4.6mm} \times 150 \mathrm{~mm}, 50$ ${ }^{\circ} \mathrm{C}$. Flow $1 \mathrm{~mL} / \mathrm{min}$, eluent $A \quad 0.1 \%$ trifluoroacetic acid in water, eluent $B 0.1 \%$ trifluoroacetic acid in $80 \%$ aqueous acetonitrile. Gradient from $0 \%$ buffer B to $100 \%$ buffer B in $30 \mathrm{~min}$. A) HPLC trace (light scattering detection). A) HPLC trace (light scattering detection).B) MS trace, calculated for M (average mass) 3160.63, observed 3160.93 after deconvolution. C) MALDI-TOF analysis. Matrix: alpha-cyano-4-hydroxy-cinnamic acid. Calculated for $[\mathrm{M}+\mathrm{H}]^{+}$(monoisotopic mass) 3159.6, observed 3159.6.

\section{Synthesis of $p 53$ peptide $4 b$}

Peptide $\mathbf{4} \mathbf{b}$ was synthesized using an automated column peptide synthesizer using standard FmocSPPS protocols $(0.05 \mathrm{mmol}$, Novasyn TGR resin, $0.25 \mathrm{mmol} / \mathrm{g}$ ). The amino acids (10 equiv) were activated using HATU (10 equiv)/DIEA (20 equiv) in DMF. Each amino acid was coupled twice. The peptidyl resin was acetylated with Ac20/DIEA in DMF after each double coupling. Lysine 386 was introduced manually as the $N$-Fmoc thiazolidine $\delta$-mercaptolysine derivative,(4) which was kindly provided by Ashraf Brik's lab.

For this, $\mathrm{N}$-Fmoc thiazolidine $\delta$-mercaptolysine derivative (38 $\mathrm{mg}, 74 \mu \mathrm{mol}, 1.5$ equiv) was preactivated with HATU ( $17.5 \mathrm{mg}, 46 \mu \mathrm{mol}, 1.5$ equiv)/DIEA ( $26 \mu \mathrm{L}, 149 \mu \mathrm{mol}, 3$ equiv) in DMF ( $0.5 \mathrm{~mL})$ during $1 \mathrm{~min}$ and then added to the peptidyl resin. The resin was agitated for $1 \mathrm{~h} 30$ and then washed , DMF $(3 \times 2 \mathrm{~min})$.

The rest of the peptide was assembled using the automated peptide synthesizer. The resin was then washed with DMF ( $3 \times 2 \mathrm{~min}), \mathrm{CH}_{2} \mathrm{Cl}_{2}(3 \times 2 \mathrm{~min})$, diethyl ether $(2 \times 2 \mathrm{~min})$ and dried in vacuo.

The peptidyl resin was finally deprotected and cleaved in TFA/TIS/EDT/ $\mathrm{H}_{2} \mathrm{O}: 92.5 / 2.5 / 2.5 / 2.5$ by vol $(10 \mathrm{~mL})$ for $1 \mathrm{~h} 30$. The crude peptide was precipitated in ice-cold heptane /diethylether : 1/1 by vol, solubilized in deionized water and lyophilized to yield $140 \mathrm{mg}$ ( $68 \%$ crude) of crude peptide. 
The thiazolidine group was removed by treated the crude peptide $(50 \mathrm{mg})$ with $O$ methylhydroxylamine ( $0.1 \mathrm{M}$ final concentration in $0.5 \mathrm{M}$ ammonium acetate, $\mathrm{pH}$ 4). After $30 \mathrm{~h}$ of stirring, the peptide was purified directly by HPLC to give $13.9 \mathrm{mg}$ (19\% overall) of peptide $\mathbf{4 b}$.

Preparative HPLC conditions for peptide 4b: XBridge BEH300 C18 (5 $\mu \mathrm{m}, 300 \AA, 20 \times 100 \mathrm{~mm})$ column, eluent $A$ water containing $0.1 \%$ of TFA, eluent $\mathrm{B} \mathrm{CH}_{3} \mathrm{CN} /$ water : $4 / 1$ by vol containing $0.1 \%$ of TFA, gradient: $5-25 \% \mathrm{~B}$ in $25 \mathrm{~min}$, flow rate $25 \mathrm{~mL} / \mathrm{min}$, UV detection at $215 \mathrm{~nm}, 50^{\circ} \mathrm{C}$.

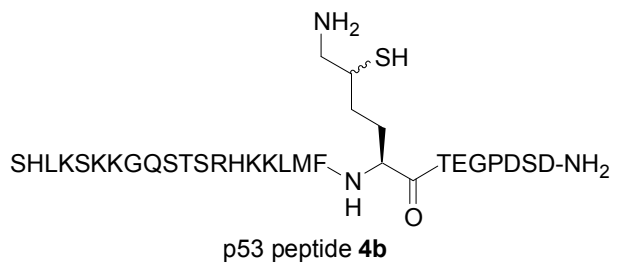

A)

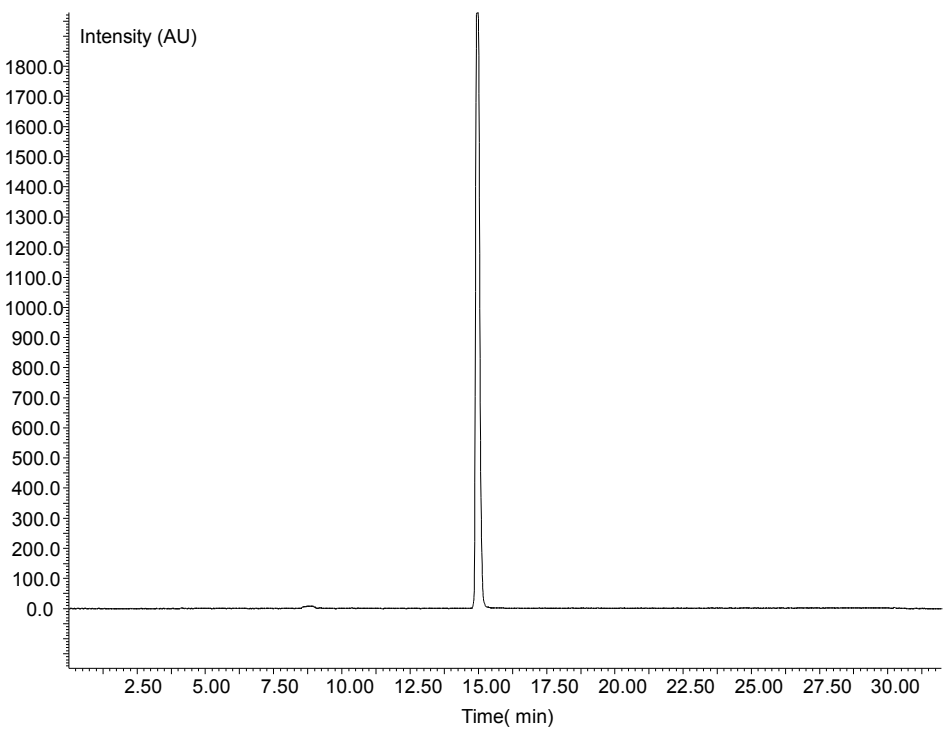


B)

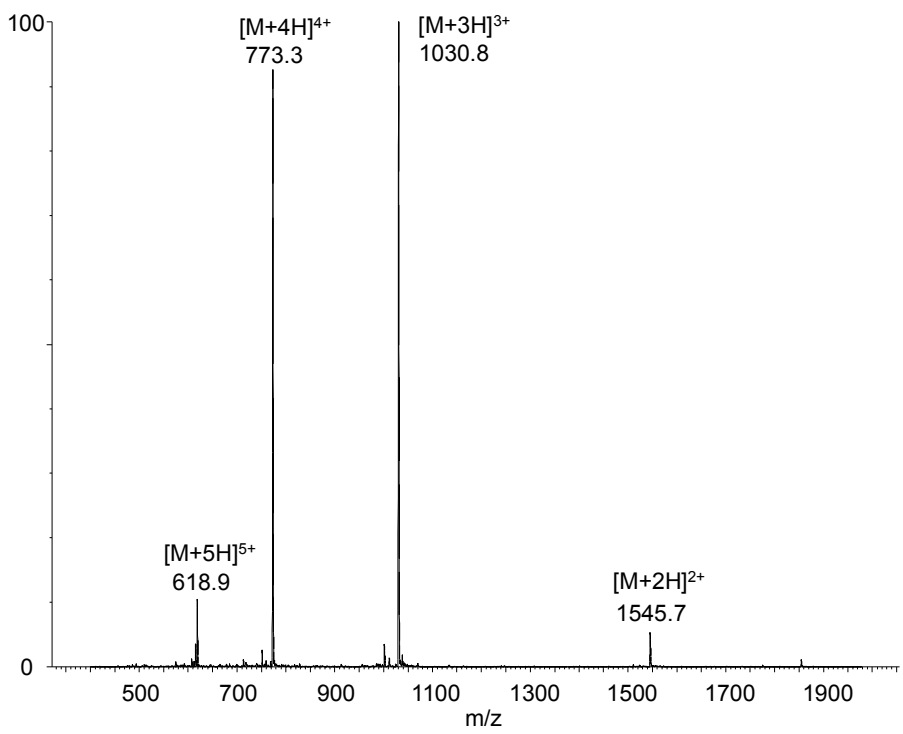

C)

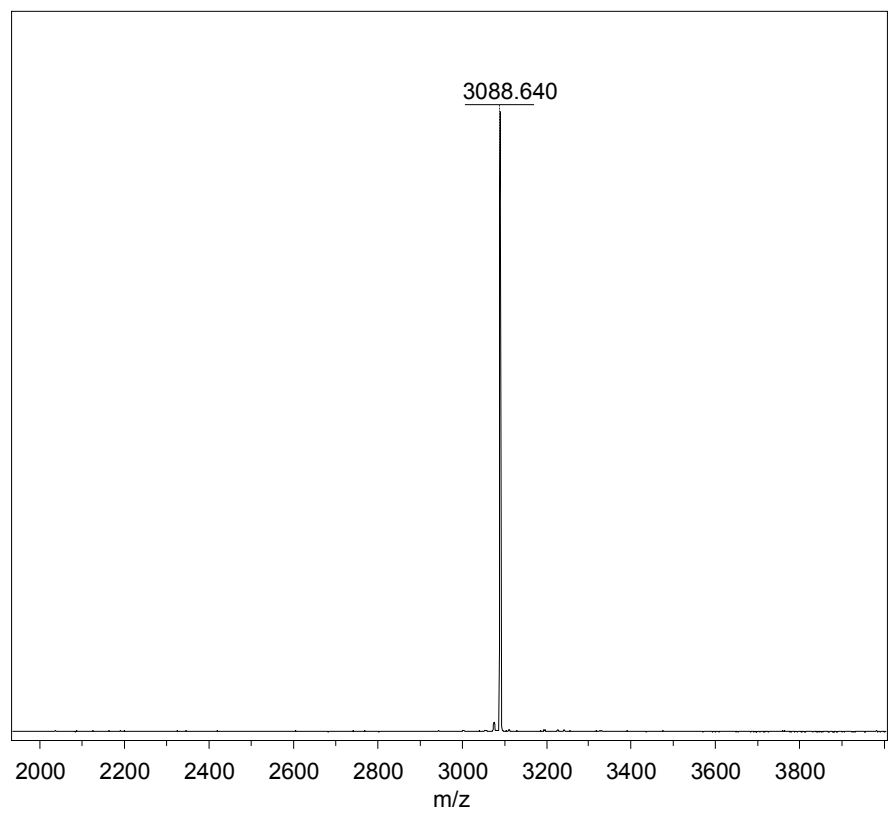

Figure S5. Analysis of peptide 4b. LC-MS analysis XBridge BEH300 C18 $3.5 \mu \mathrm{m} \mathrm{4.6mm} \times 150 \mathrm{~mm}, 50$ ${ }^{\circ} \mathrm{C}$. Flow $1 \mathrm{~mL} / \mathrm{min}$, eluent A $0.1 \%$ trifluoroacetic acid in water, eluent $B 0.1 \%$ trifluoroacetic acid in $80 \%$ aqueous acetonitrile. Gradient from $0 \%$ buffer B to $100 \%$ buffer B in 30 min. A) HPLC trace (light scattering detection). B) MS trace, calculated for M (average mass) 3089.55, observed 3089.46 after deconvolution. C) MALDI-TOF analysis. Matrix: alpha-cyano-4-hydroxy-cinnamic acid. Calculated for $[\mathrm{M}+\mathrm{H}]^{+}$(monoisotopic mass) 3088.571, observed 3088.640. 
Synthesis of p53 SUMO-1 peptide protein conjugates

\section{One-pot synthesis of p53 SUMO-1 peptide conjugate $5 a$}

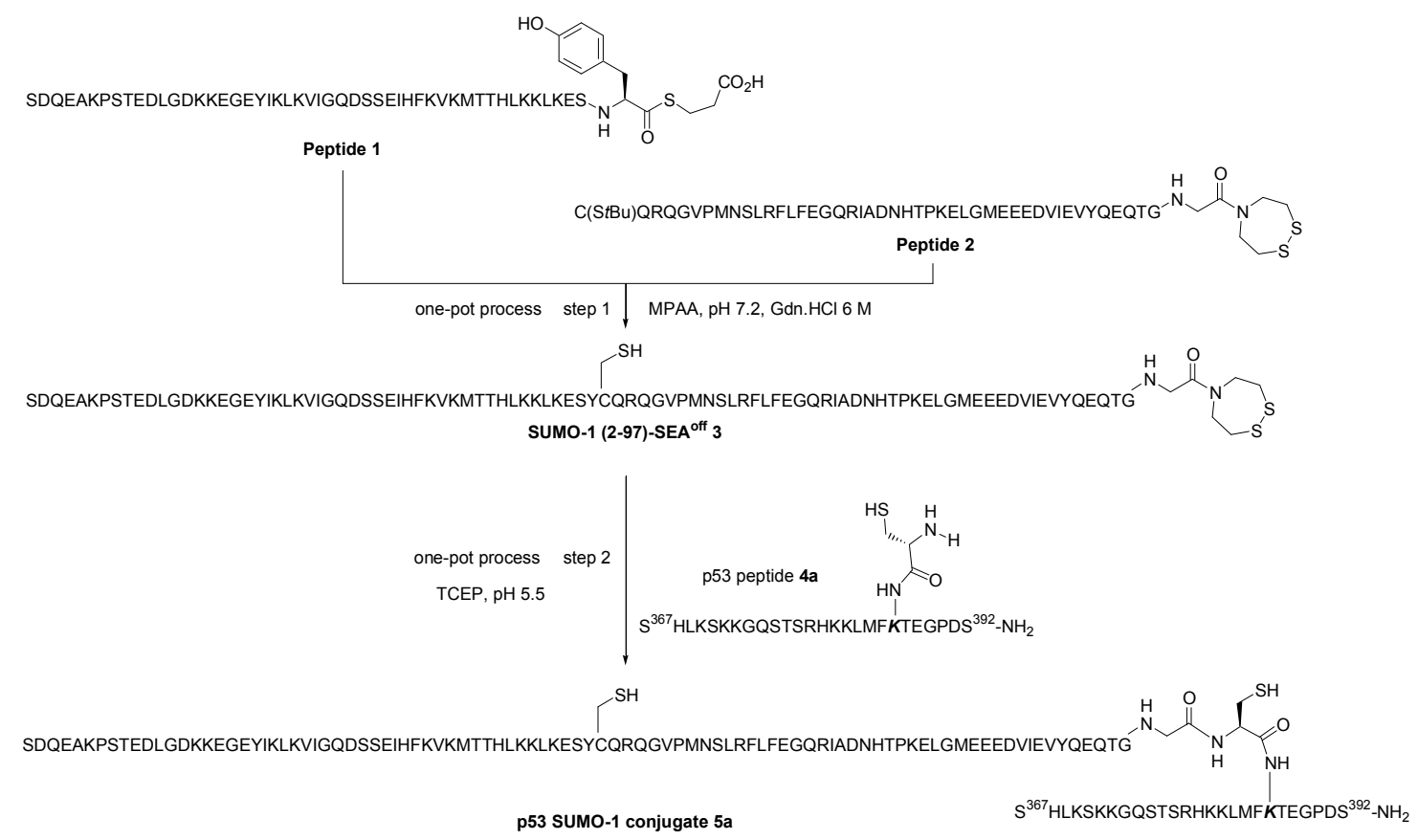

Scheme S3. One-pot synthesis of p53 SUMO-1 peptide conjugate $\mathbf{5 a}$.

The whole process was carried under nitrogen atmosphere.

First ligation step (NCL):

A solution of 4-mercaptophenylacetic acid (MPAA, $26.9 \mathrm{mg}, 0.159 \mathrm{mmol}$ ) in $6 \mathrm{M}$ guanidinium chloride/0.1 M pH 7.0 sodium phosphate buffer was prepared $(0.8 \mathrm{~mL})$. Peptide thioester $1(8.31 \mathrm{mg}$, $1.13 \mu \mathrm{mol})$ and $\mathrm{SEA}^{\text {off }}$ peptide segment $2(7.01 \mathrm{mg}, 1.13 \mu \mathrm{mol})$ were dissolved in the above solution $(379 \mu \mathrm{L}$ ) and the $\mathrm{pH}$ was adjusted to 7.2 by addition of aqueous $\mathrm{NaOH} 6 \mathrm{~N}$. The reaction was agitated for $6 \mathrm{~h}$ at $37^{\circ} \mathrm{C}$.

Second ligation step (SEA ligation):

Then, a solution of TCEP $(24.14 \mathrm{mg}, 84.20 \mu \mathrm{mol})$ and MPAA $(14.16 \mathrm{mg}, 84.20 \mu \mathrm{mol})$ in $6 \mathrm{M}$ guanidinium hydrochloride/0.1 M pH 7.0 sodium phosphate buffer $(420 \mu \mathrm{L})$ was prepared and used to dissolve p53 peptide $4 \mathrm{a}(9.52 \mathrm{mg}, 2.27 \mu \mathrm{mol})$. The $\mathrm{pH}$ of this solution was 4.1. The peptide solution was then added to the above reaction mixture and the $\mathrm{pH}$ was adjusted to 5.6 by addition of aqueous $\mathrm{NaOH}(10 \mu \mathrm{L})$.The final peptide concentration was $1.5 \mathrm{mM}$. The reaction was agitated for 36 $\mathrm{h}$ and then diluted with water $(3 \mathrm{~mL})$, acidified to $\mathrm{pH} 3$ by adding $10 \%$ aqueous TFA and extracted with diethylether $(3 \times 2 \mathrm{~mL})$ to remove the excess of MPAA. The mixture was immediately purified by HPLC to yield $7.45 \mathrm{mg}(38 \%)$ of p53 SUMO-1 conjugate 5 a. 
Semi-preparative HPLC conditions: C3 Zorbax column ( $5 \mu \mathrm{m}, 300 \AA$, $9.4 \times 250 \mathrm{~mm}$, Agilent), detection at $215 \mathrm{~nm}$, flow rate $6 \mathrm{~mL} / \mathrm{min}$, eluent $A$ water containing $0.1 \%$ of TFA, eluent $B \mathrm{CH}_{3} \mathrm{CN} /$ water : 4/1 by vol containing $0.1 \%$ of TFA, gradient $0-50 \% \mathrm{~B}$ in $30 \mathrm{~min}, 50^{\circ} \mathrm{C}$.

\section{Characterization of p53 SUMO-1 conjugate $5 a$}

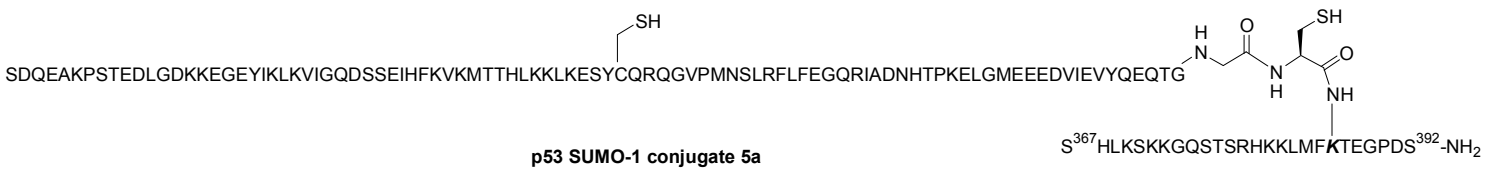

A)

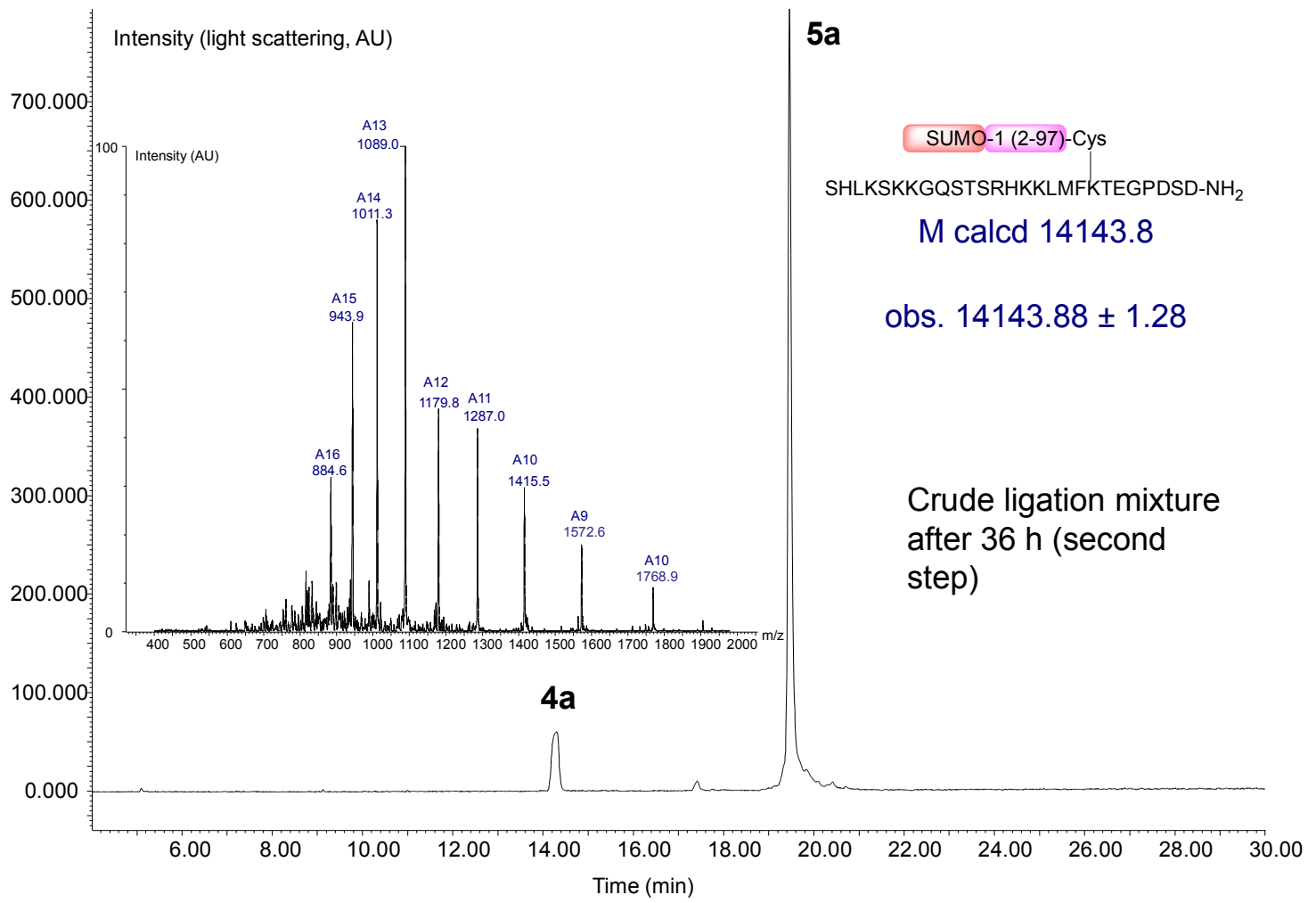


B)

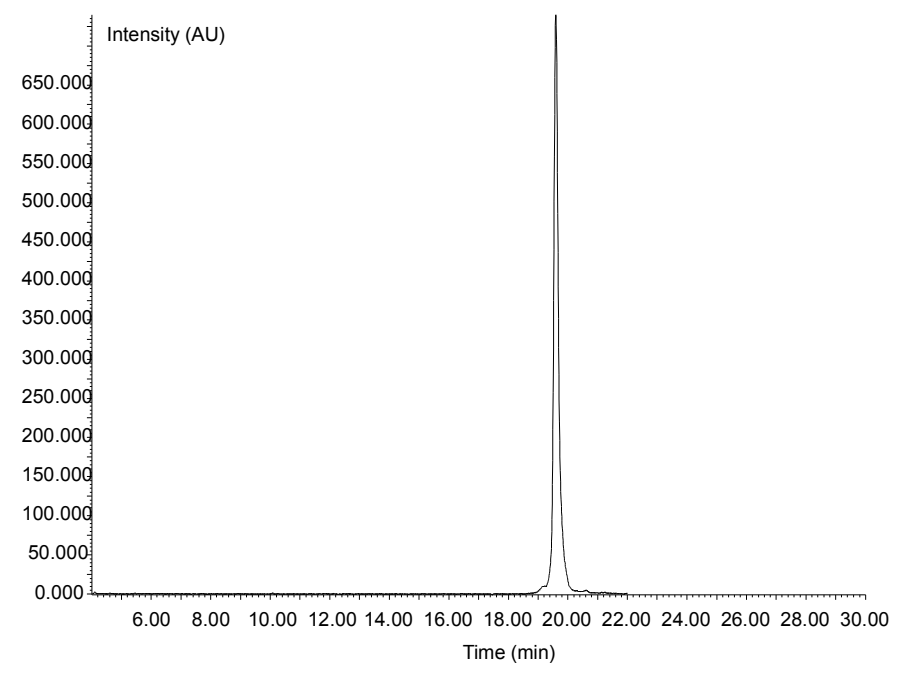

C)

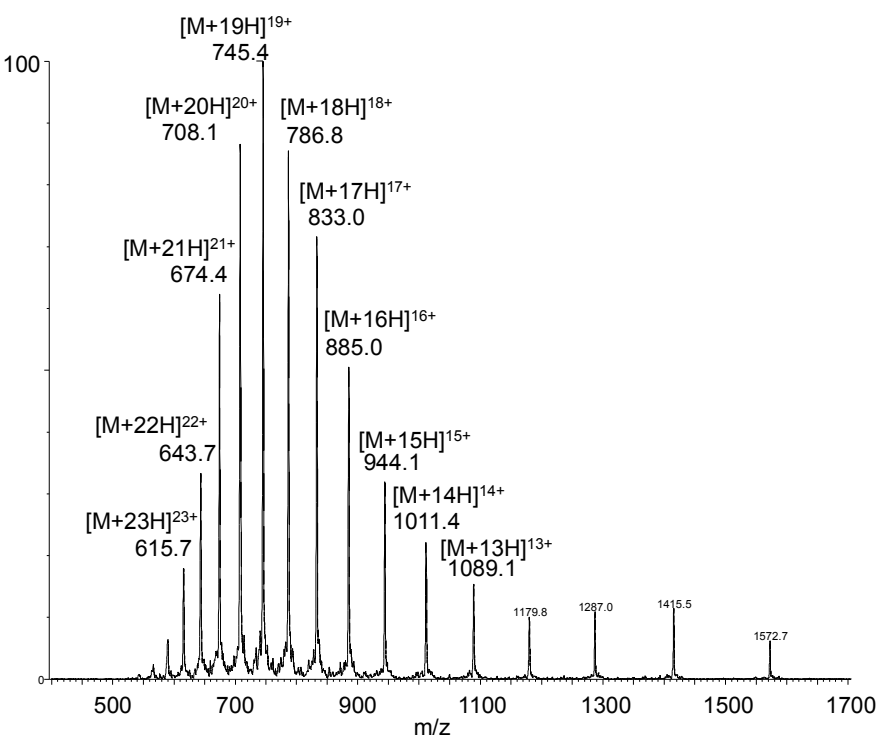


D)

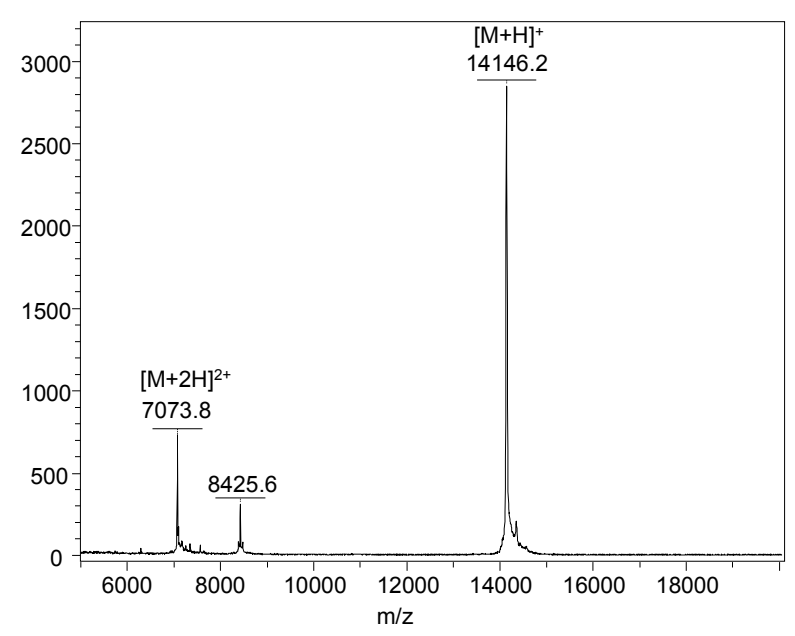

E)

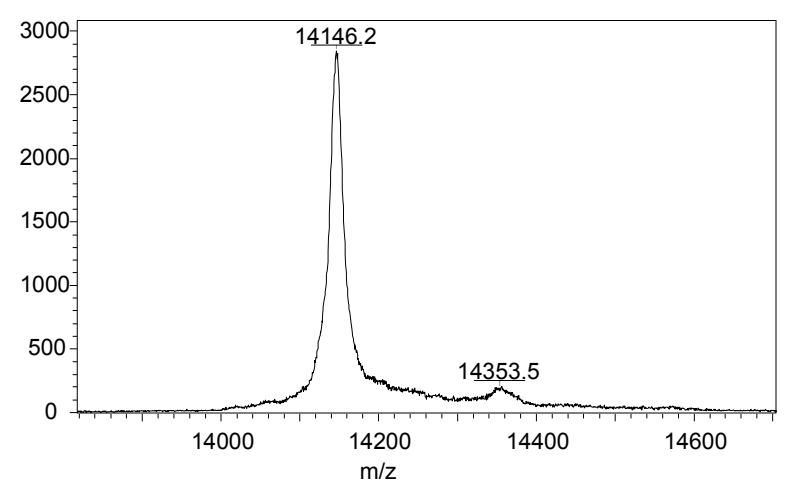

F)

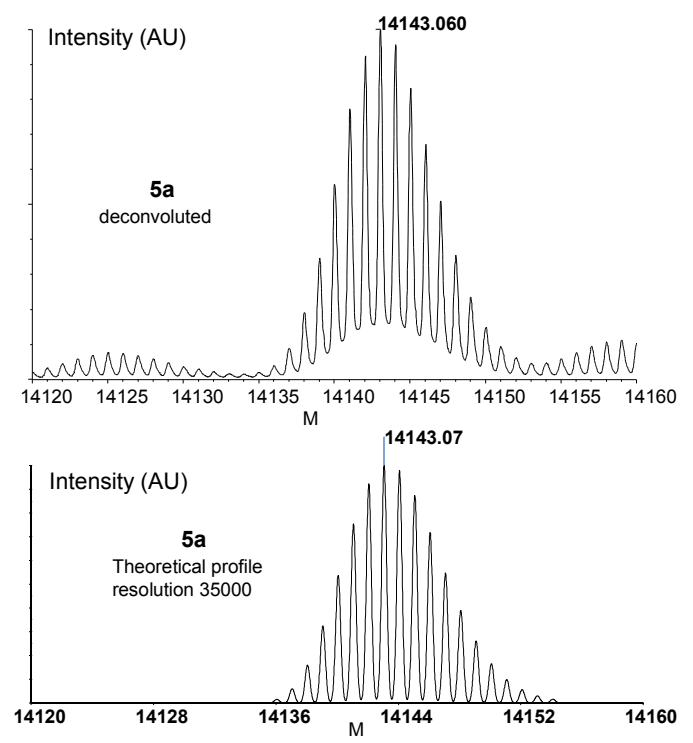


Figure S6. Analysis of p53 SUMO-1 conjugate 5a. A) LC-MS analysis of the crude one-pot mixture, HPLC trace (light scattering detection). XBridge BEH300 C18 $3.5 \mu \mathrm{m} \mathrm{4.6mm} \times 150 \mathrm{~mm}, 50{ }^{\circ} \mathrm{C}$. Flow 1 $\mathrm{mL} / \mathrm{min}$, eluent $\mathrm{A} 0.1 \%$ formic acid in water, eluent $\mathrm{B} 0.1 \%$ formic acid in $80 \%$ aqueous acetonitrile. Gradient from $0 \%$ buffer B to $50 \%$ buffer B in $30 \mathrm{~min}$. B) LC-MS analysis of the purified conjugate $\mathbf{5 a}$. C) MS trace, calculated for $M$ (average mass) 14143.8, observed 14142.8 after deconvolution. D \& E) MALDI-TOF analysis. Matrix: sinapinic acid, calculated for $[\mathrm{M}+\mathrm{H}]^{+}$(average mass)-14144.8, observed $14146.2 \mathrm{~F}) \mathrm{HRMS}$ reconstructed mass and theoretical profile for $\mathrm{C}_{611} \mathrm{H}_{984} \mathrm{~N}_{174} \mathrm{O}_{199} \mathrm{~S}_{6}$ at resolution 35000.

MALDI-TOF in source fragmentation of p53 SUMO-1 conjugate 5a. Proof of structure

A)

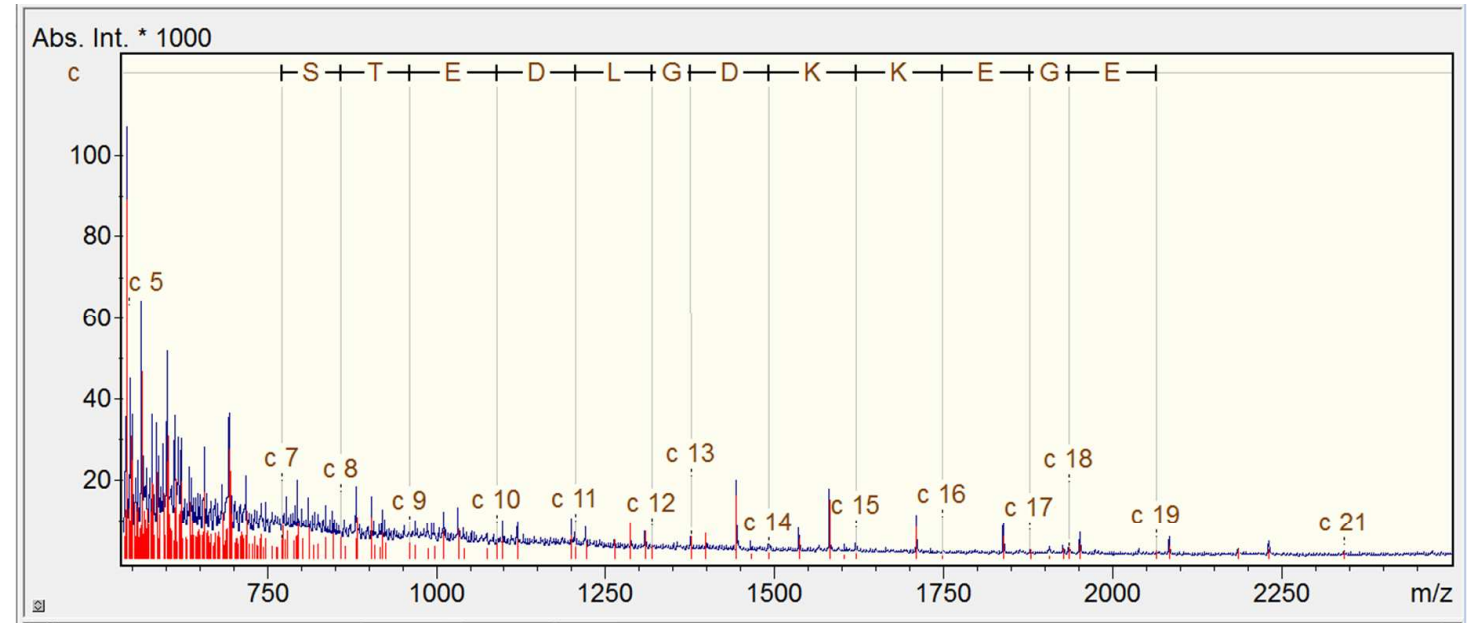

B)

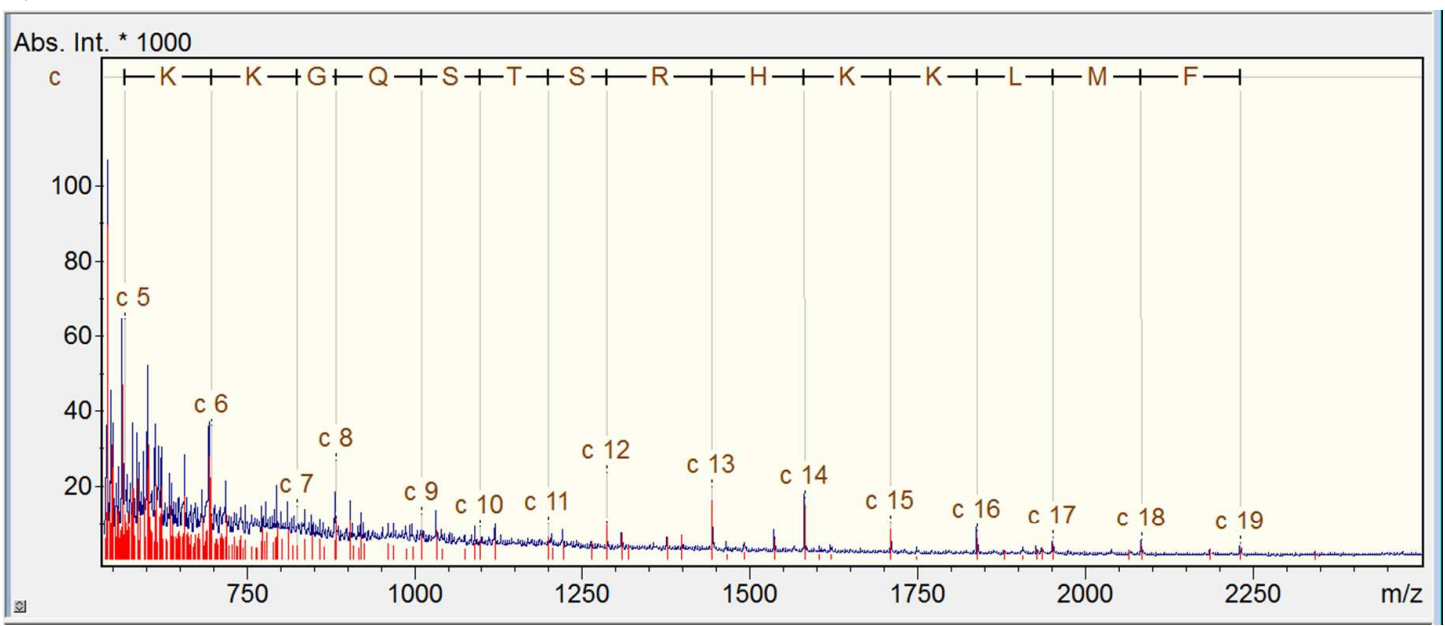


C)

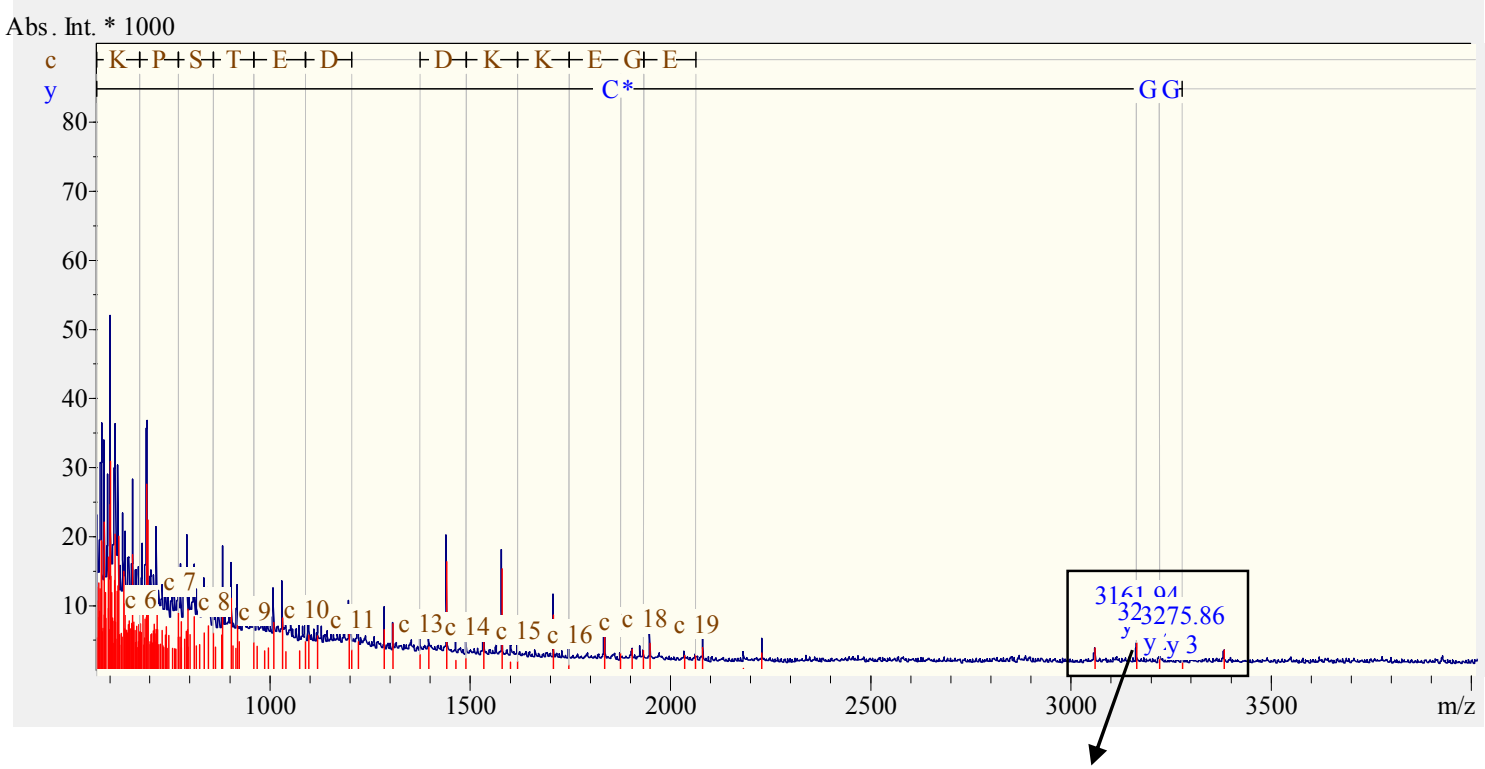

D)

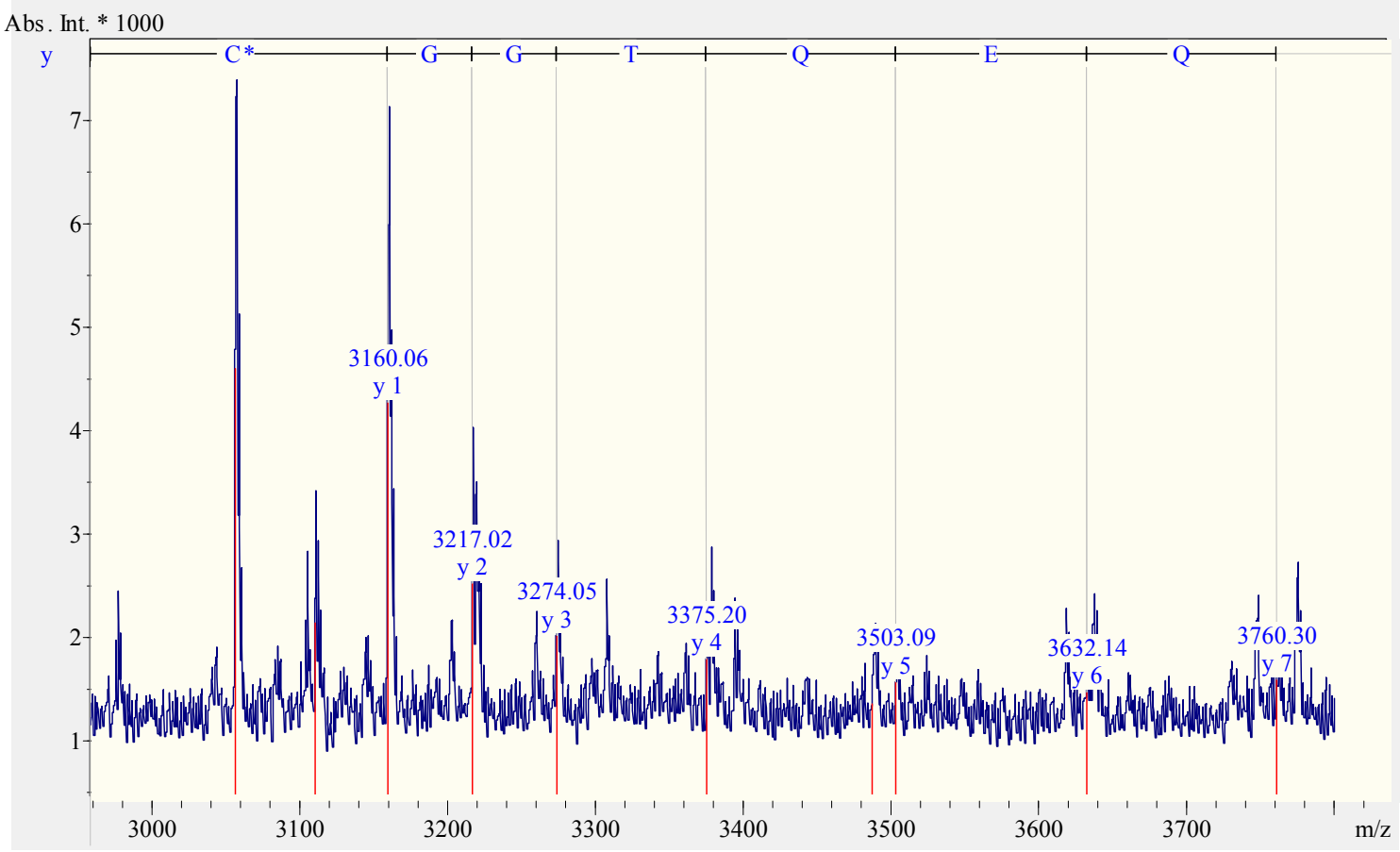


E)

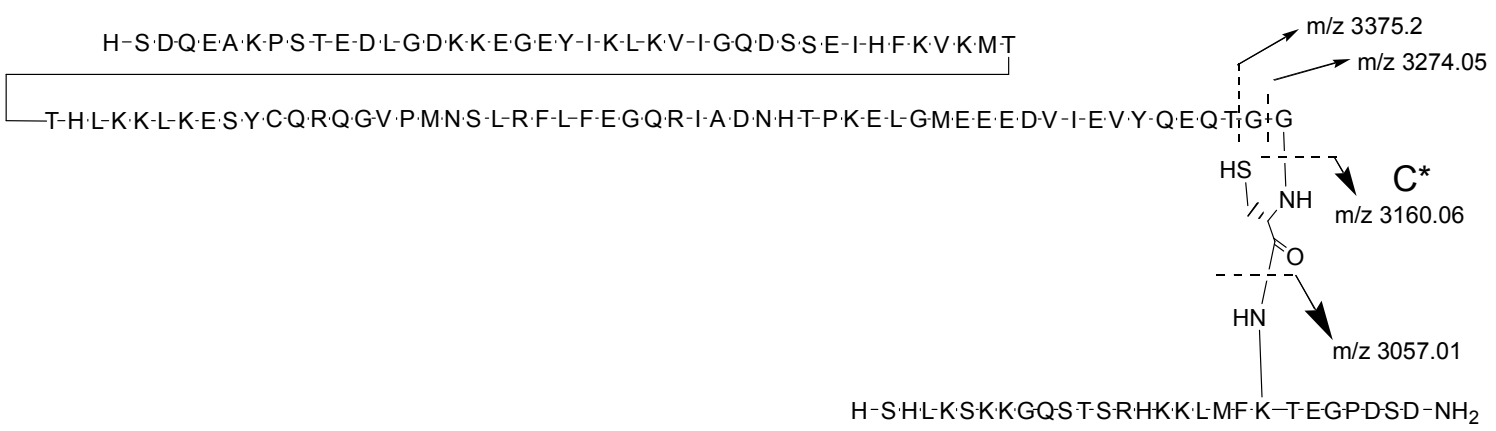

Figure S7. In source MALDI-TOF sequencing using 2,5-dihydroxybenzoic acid as matrix (positive reflector mode). Ions corresponding to the $\mathrm{N}$-terminal part of SUMO-1 domain (A) or target peptide (B) could be identified. The y ions shown in (C-E) show the formation of the peptide bond between the C-terminal Gly residue of SUMO-1 protein and the Cys residue of the target peptide. $\mathrm{C}^{*}$ is for the $y$ ion at $\mathrm{m} / \mathrm{z} 3160.06$ which corresponds to the p53 peptide plus the C-terminal Cys residue.

\section{One-pot synthesis of p53 SUMO-1 peptide conjugate $5 b$}

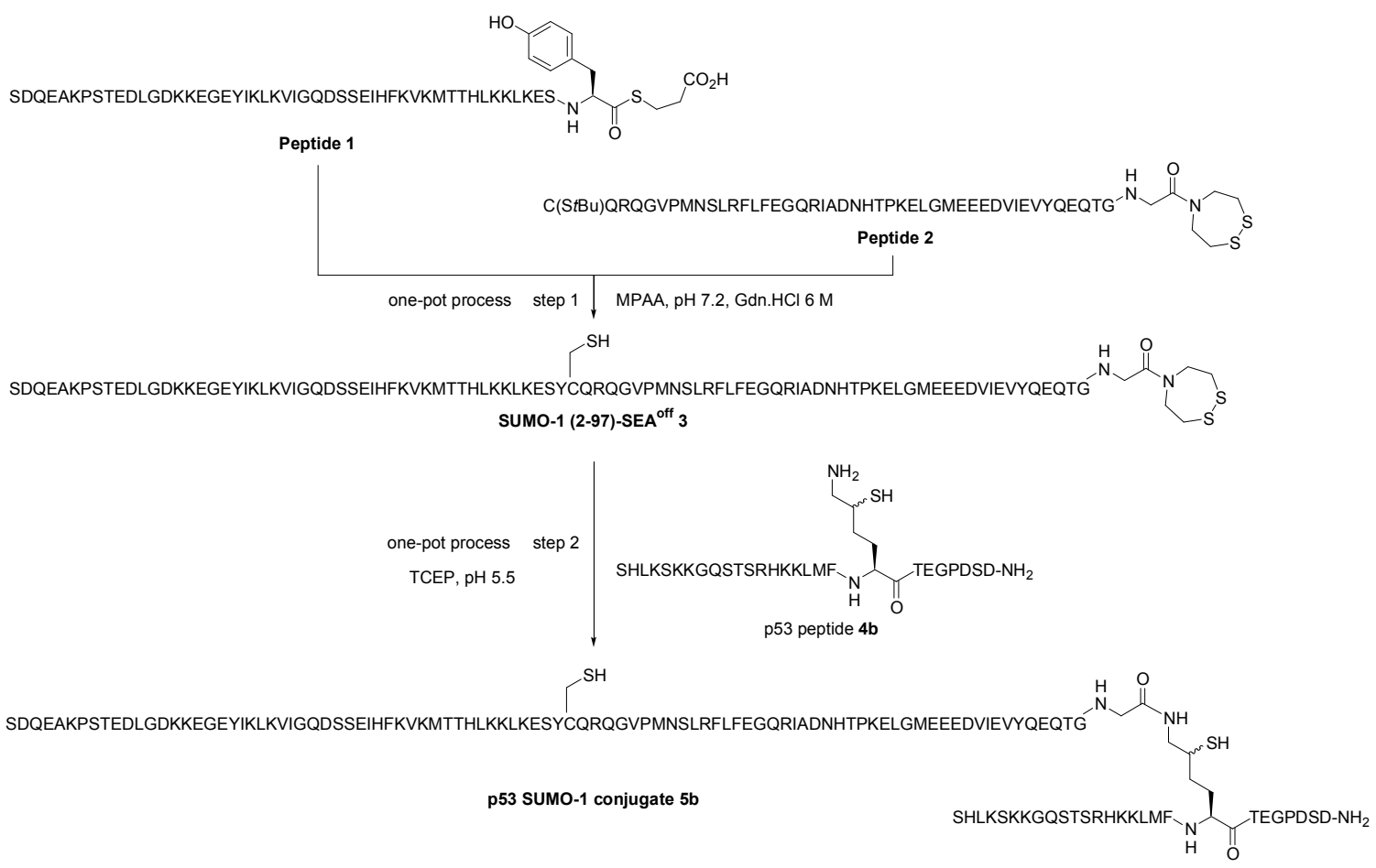

Scheme S4. One-pot synthesis of p53 SUMO-1 peptide conjugate $\mathbf{5 b}$.

The one-pot assembly was performed in an inert atmosphere (nitrogen). 
First ligation step (NCL):

A solution of 4-mercaptophenylacetic acid (MPAA, $33.64 \mathrm{mg}, 0.2000 \mathrm{mmol}$ ) in $6 \mathrm{M}$ guanidinium chloride/0.1 M pH 7.0 sodium phosphate buffer was prepared $(1 \mathrm{~mL})$. Peptide thioester $1(9.33 \mathrm{mg}$, $1.27 \mu \mathrm{mol})$ and SEA ${ }^{\text {off }}$ peptide segment $2(7.88 \mathrm{mg}, 1.27 \mu \mathrm{mol})$ were dissolved in the above solution $(426 \mu \mathrm{L})$ and the $\mathrm{pH}$ was adjusted to 7.35 by addition of aqueous $6 \mathrm{~N} \mathrm{NaOH}$. The reaction was agitated for $3 \mathrm{~h}$ at $37^{\circ} \mathrm{C}$.

Second ligation step (SEA ligation):

Then, a solution of TCEP $(32.68 \mathrm{mg}, 0.1140 \mathrm{mmol})$ and MPAA $(19.17 \mathrm{mg}, 0.1140 \mathrm{mmol})$ in $6 \mathrm{M}$ guanidine hydrochloride/0.1 M pH 7.0 sodium phosphate buffer $(570 \mu \mathrm{L})$ was prepared and used to dissolve p53 peptide $\mathbf{4 b}(6.48 \mathrm{mg}, 1.53 \mu \mathrm{mol}, 255 \mu \mathrm{L}$ of the above solution). The $\mathrm{pH}$ of this solution was 3.8. The $\mathrm{p} 53$ peptide solution was then added to the above reaction mixture and the $\mathrm{pH}$ was adjusted to 5.57 by addition of aqueous $6 \mathrm{~N} \mathrm{NaOH}(2 \mu \mathrm{L})$. The final peptide concentration was 1.9 $\mathrm{mM}$. The reaction was agitated for $120 \mathrm{~h}$ and then diluted with water $(3 \mathrm{~mL})$, acidified to $\mathrm{pH} 3$ by adding $10 \%$ aqueous TFA and extracted with diethylether $(3 \times 2 \mathrm{~mL})$ to remove the excess of MPAA. The mixture was immediately purified by HPLC to yield $5.84 \mathrm{mg}$ of p53 SUMO-1 conjugate $5 \mathbf{b}$ (27\%).

HPLC conditions for the purification: C3 Zorbax column (5 $\mu \mathrm{m}, 300 \AA .9 .4 \times 250 \mathrm{~mm}$, Agilent), detection at $215 \mathrm{~nm}$, flow rate $6 \mathrm{~mL} / \mathrm{min}, 50{ }^{\circ} \mathrm{C}$, eluent $A$ water containing $0.1 \%$ of TFA, eluent $B$ $\mathrm{CH}_{3} \mathrm{CN} /$ water : $4 / 1$ by vol containing $0.1 \%$ of TFA, gradient $0-50 \% \mathrm{~B}$ in $30 \mathrm{~min}$. 
A)

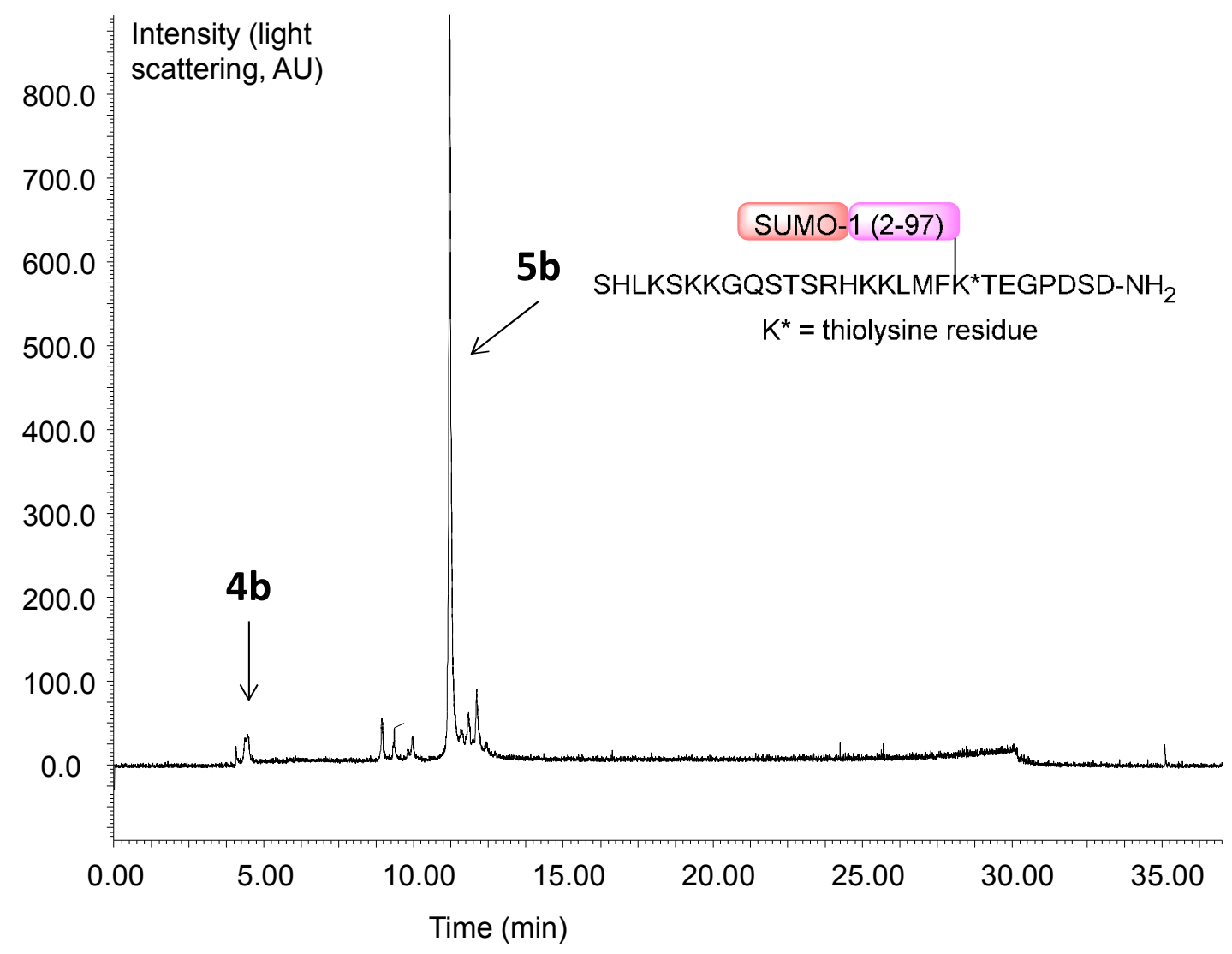

B)

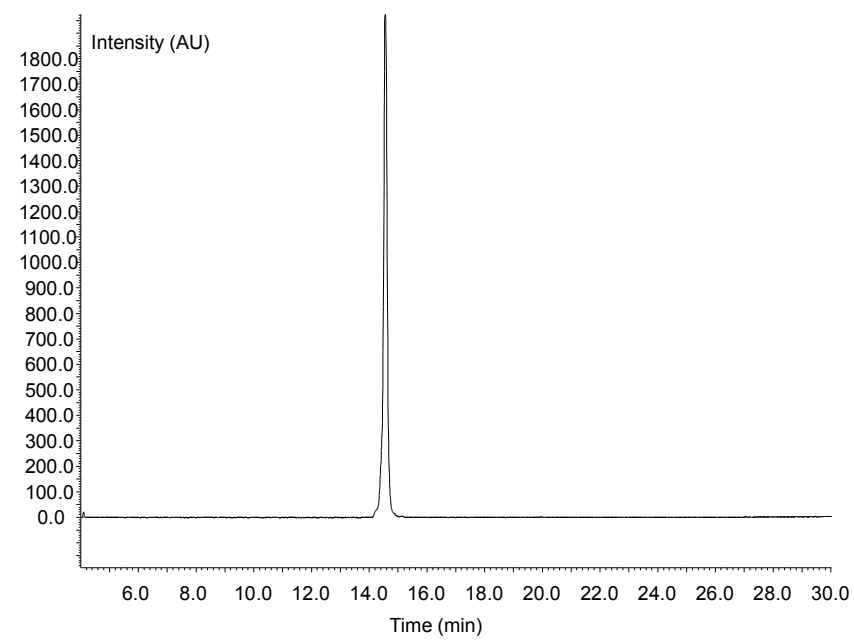


C)

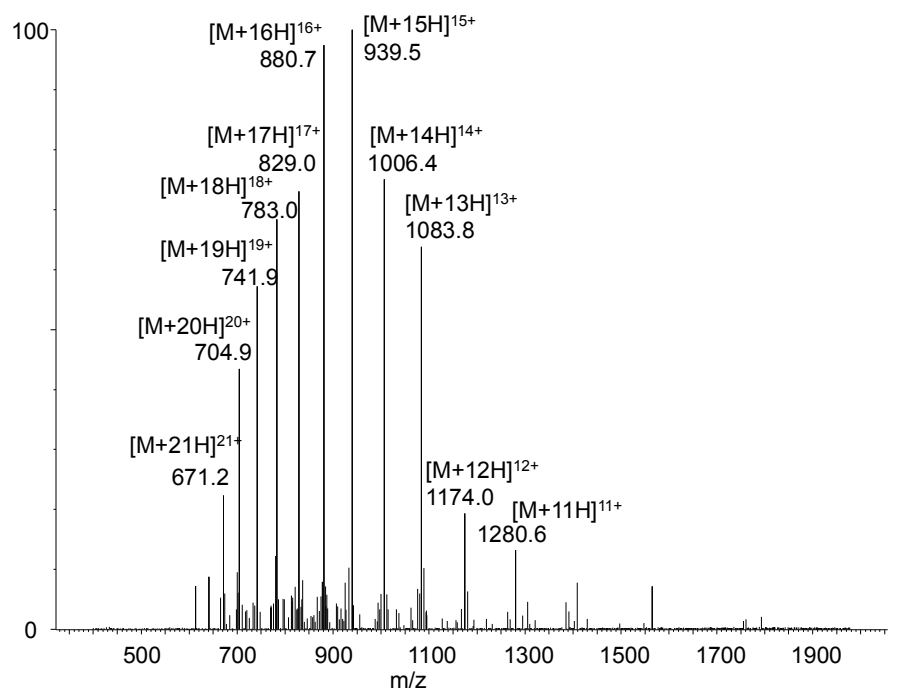

D)

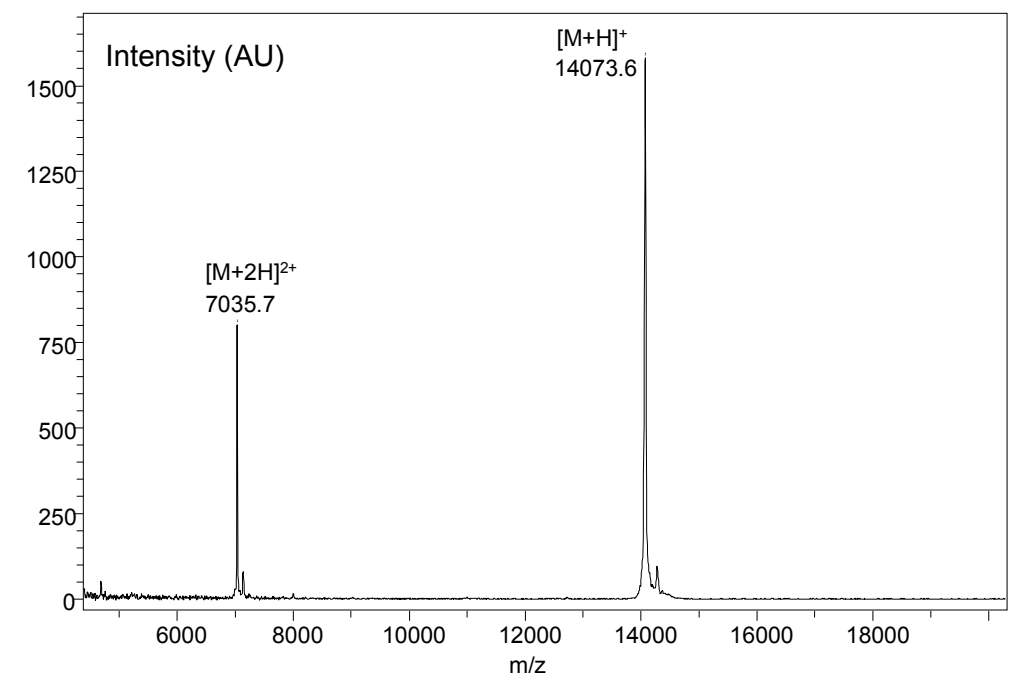


E)

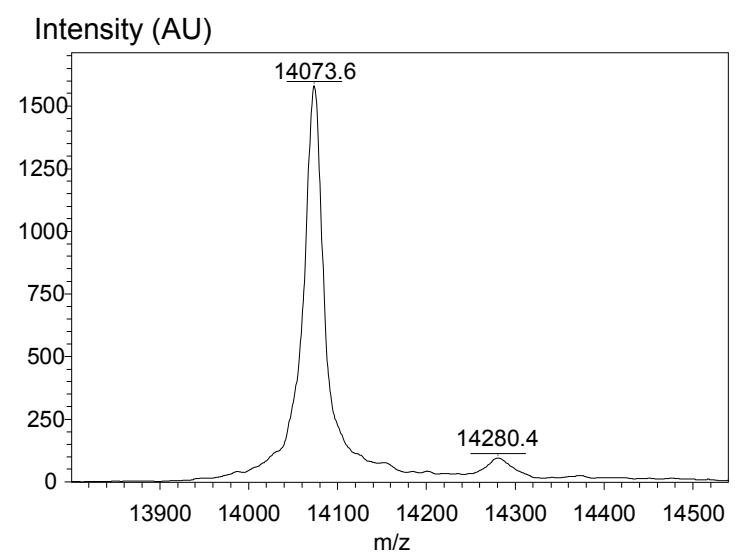

F)

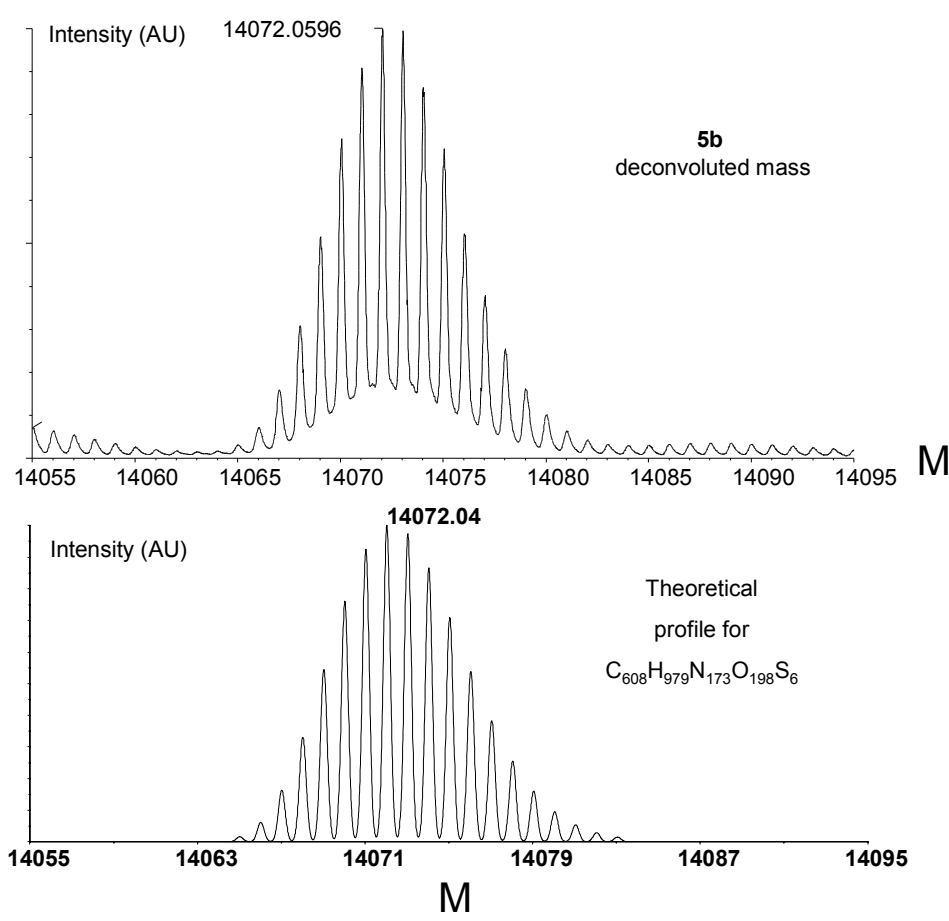

Figure S8. Analysis of p53 SUMO-1 conjugate 5b. A) LC-MS analysis of the crude one-pot mixture after $120 \mathrm{~h}$ for the second step, HPLC trace (light scattering detection). C3 Zorbax column (5 $\mu \mathrm{m}, 300$ $\AA$ A $9.4 \times 250 \mathrm{~mm}$, Agilent), $50{ }^{\circ} \mathrm{C}$. Flow $1 \mathrm{~mL} / \mathrm{min}$, eluent $\mathrm{A} 0.1 \%$ formic acid in water, eluent $\mathrm{B} 0.1 \%$ formic acid in $80 \%$ aqueous acetonitrile. Gradient from $0 \%$ buffer B to $50 \%$ buffer B in $30 \mathrm{~min}$. B) LCMS analysis of the purified conjugate $5 \mathrm{~b}$. C) MS trace, calculated for M (average mass) 14071.89, observed 14075.49 after deconvolution. D \& E) MALDI-TOF analysis. Matrix: sinapinic acid, calculated 
for $[\mathrm{M}+\mathrm{H}]^{+}$(average mass) 14073.8, observed 14073.6. F) HRMS reconstructed mass and theoretical profile for $\mathrm{C}_{608} \mathrm{H}_{979} \mathrm{~N}_{173} \mathrm{O}_{198} \mathrm{~S}_{6}$ at resolution 35000 .

MALDI-TOF in source fragmentation of p53 SUMO-1 conjugate 5b. Proof of structure

A)

\section{Fragmentation of SUMO-1 domain}

SDQEAKPSTEDLGDKKEGEYIKLKVIGQDSSEIHFKVKMTTHLKKLKESYCQRQGVPMNSLRFLFEGQRIADNHTPKELGM...
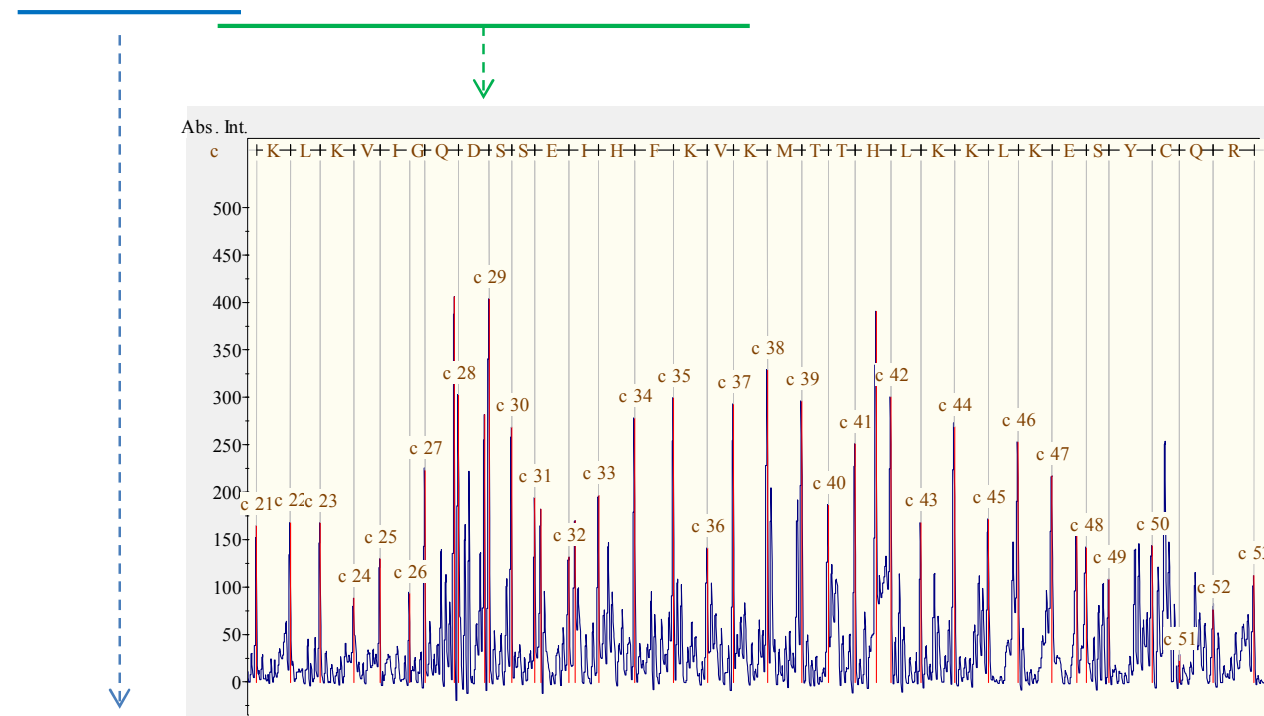

500

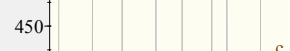

400

350
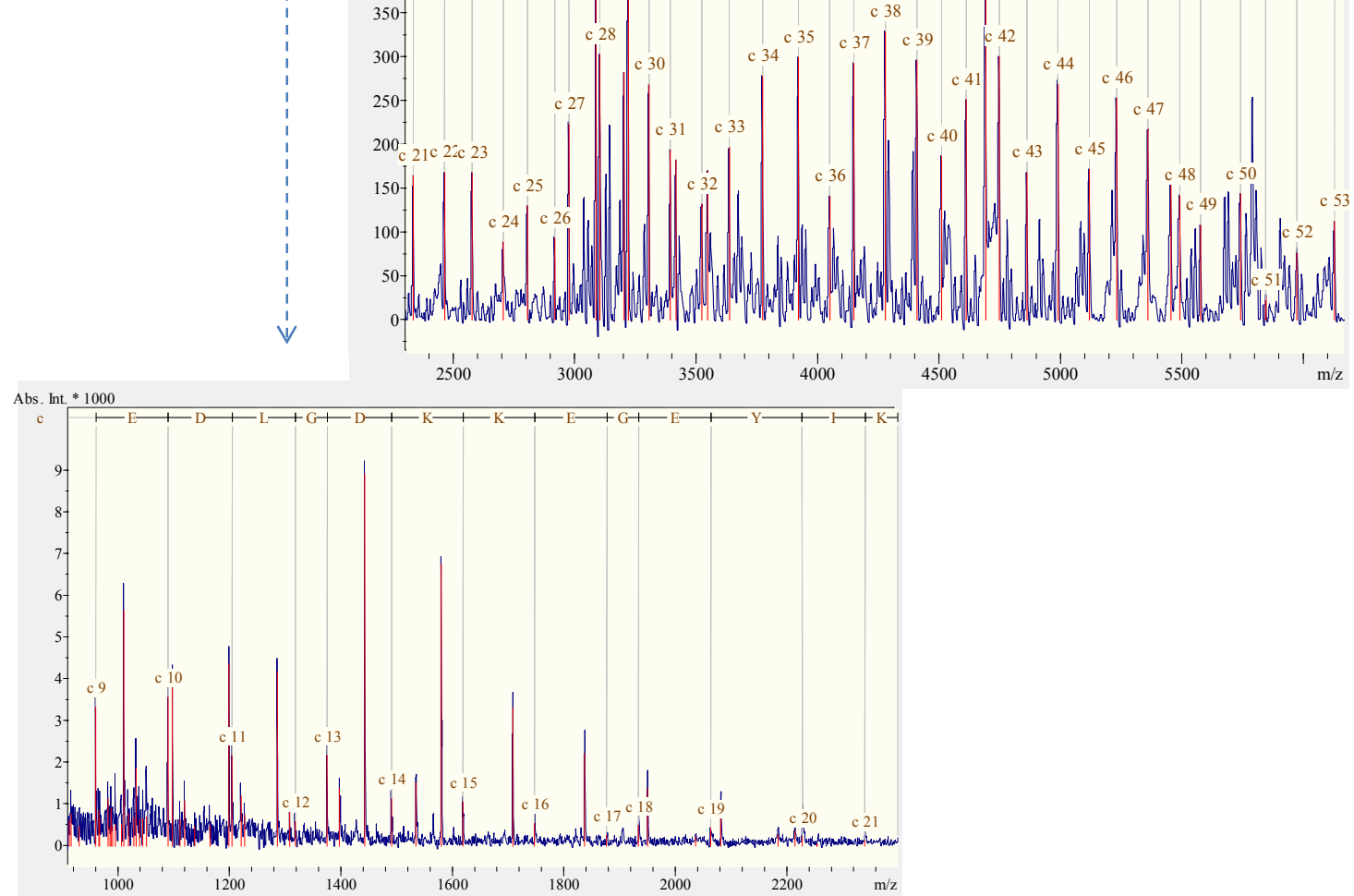
B)

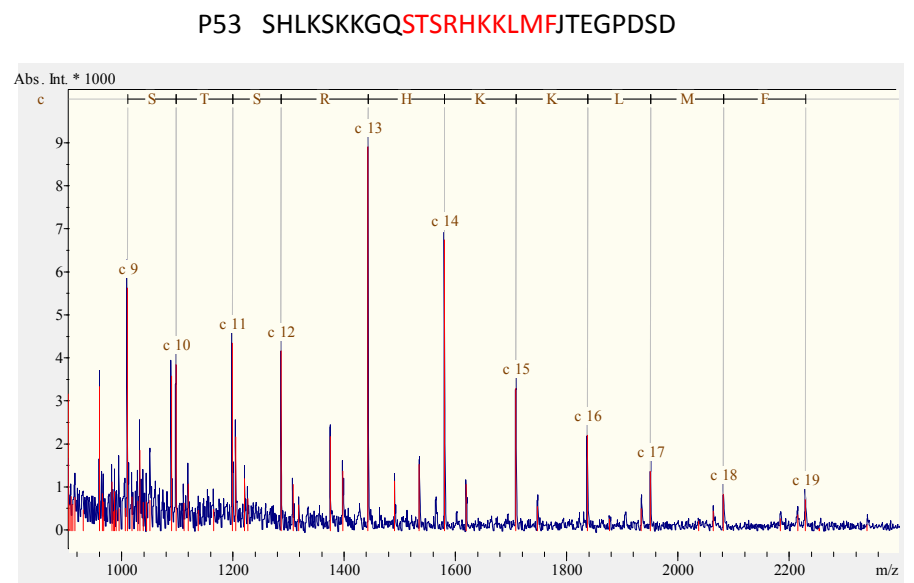

C)
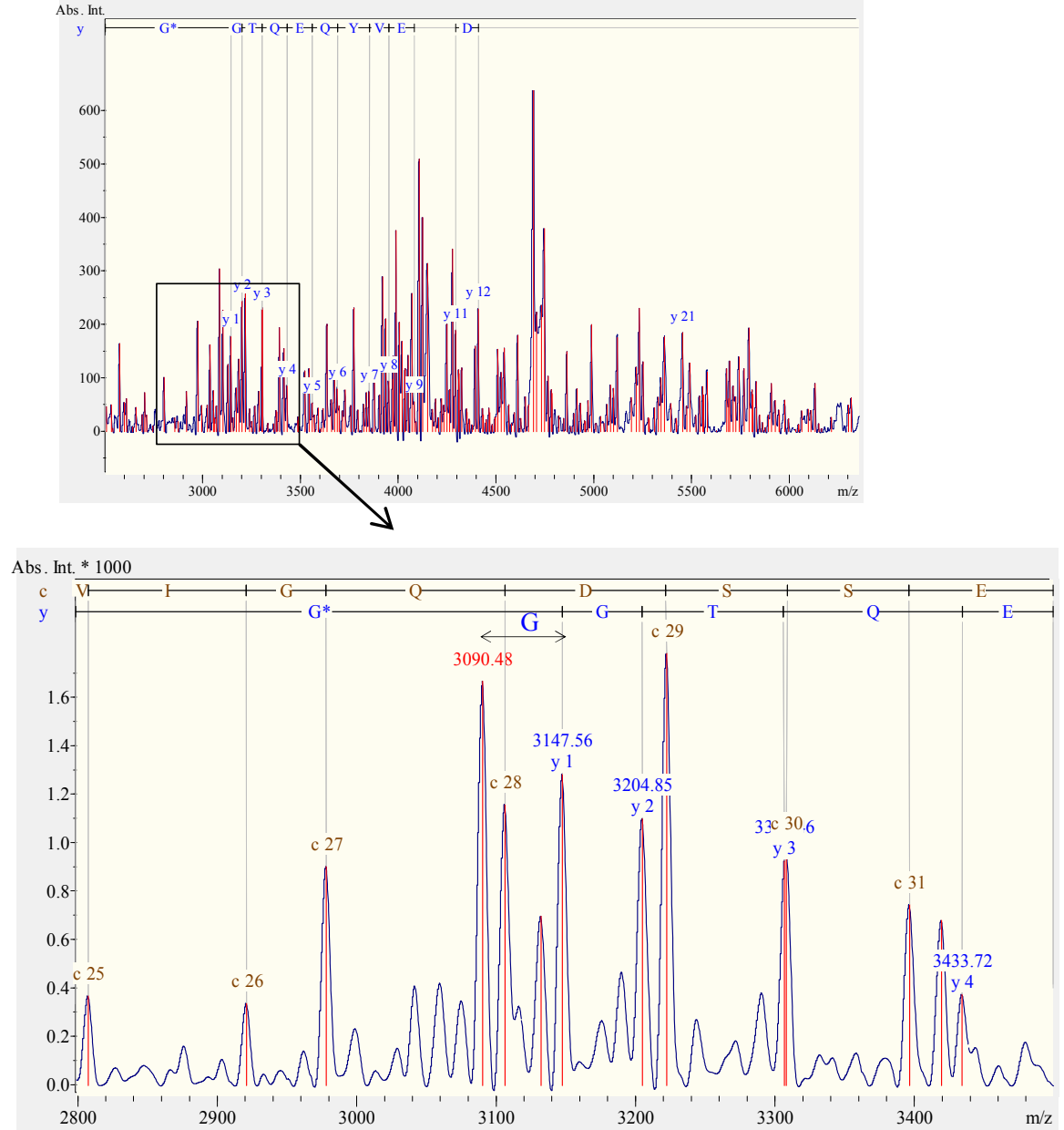
D)

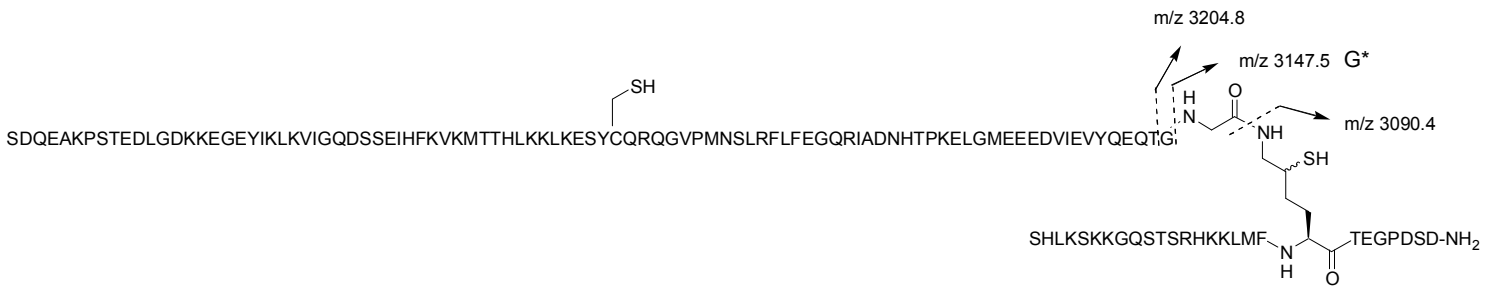

Figure 59. In source MALDI-TOF sequencing using 2,5-dihydroxybenzoic acid as matrix (positive reflector mode). $\mathrm{C}$ ions corresponding to the $\mathrm{N}$-terminal part of SUMO-1 domain (A) or target peptide (B) could be identified. Importantly, the y ions detected in (C) show the formation of the peptide bond between the C-terminal Gly residue of SUMO-1 protein and the target peptide (D). G* is for the $y$ ion at $\mathrm{m} / \mathrm{z} 3147.5$ which corresponds to the $\mathrm{p} 53$ peptide plus the C-terminal Gly residue.

\section{Synthesis of conjugate $6 a$ by selective desulfurization of conjugate $5 a$}

\section{Desulfurization of conjugate $5 a$ in native conditions}

Conjugate $5 a$ a (3,4 mg, $2.4 \mu \mathrm{mol}, 1 \mathrm{mM}$ final concentration) was dissolved in a solution of TCEP (57.31 $\mathrm{mg} / \mathrm{mL}, 200 \mathrm{mM}$ final concentration), 2,2'-azobis[2-(2-imidazolin-2-yl)propane]dihydrochloride (VA$044,0.43 \mathrm{mg} / \mathrm{mL}, 1.33 \mathrm{mM}$ final concentration) and reduced glutathione $(6.15 \mathrm{mg} / \mathrm{mL}, 20 \mathrm{mM}$ final concentration) in $0.1 \mathrm{M} \mathrm{pH} 7.2$ ammonium phosphate buffer $(2440 \mu \mathrm{L})$. The desulfurization was carried out at $25^{\circ} \mathrm{C}$ and monitored by MALDI-TOF mass spectrometry.

After $14 \mathrm{~h}$, the reaction product was purified by HPLC to yield $662 \mu \mathrm{g}(19 \%)$ of pure conjugate $6 \mathrm{a}$.

HPLC conditions: C3 Zorbax $300 \AA$ A column, detection at $215 \mathrm{~nm}$, flow rate $6 \mathrm{~mL} / \mathrm{min}$, eluent A water containing $0.1 \%$ of $\mathrm{HCl}$, eluent $\mathrm{B} \mathrm{CH} \mathrm{CH}_{3} \mathrm{CN} /$ water : $60 / 40$ by vol containing $0.1 \%$ of $\mathrm{HCl}$, gradient $0-80 \% \mathrm{~B}$ in $60 \mathrm{~min}$. 


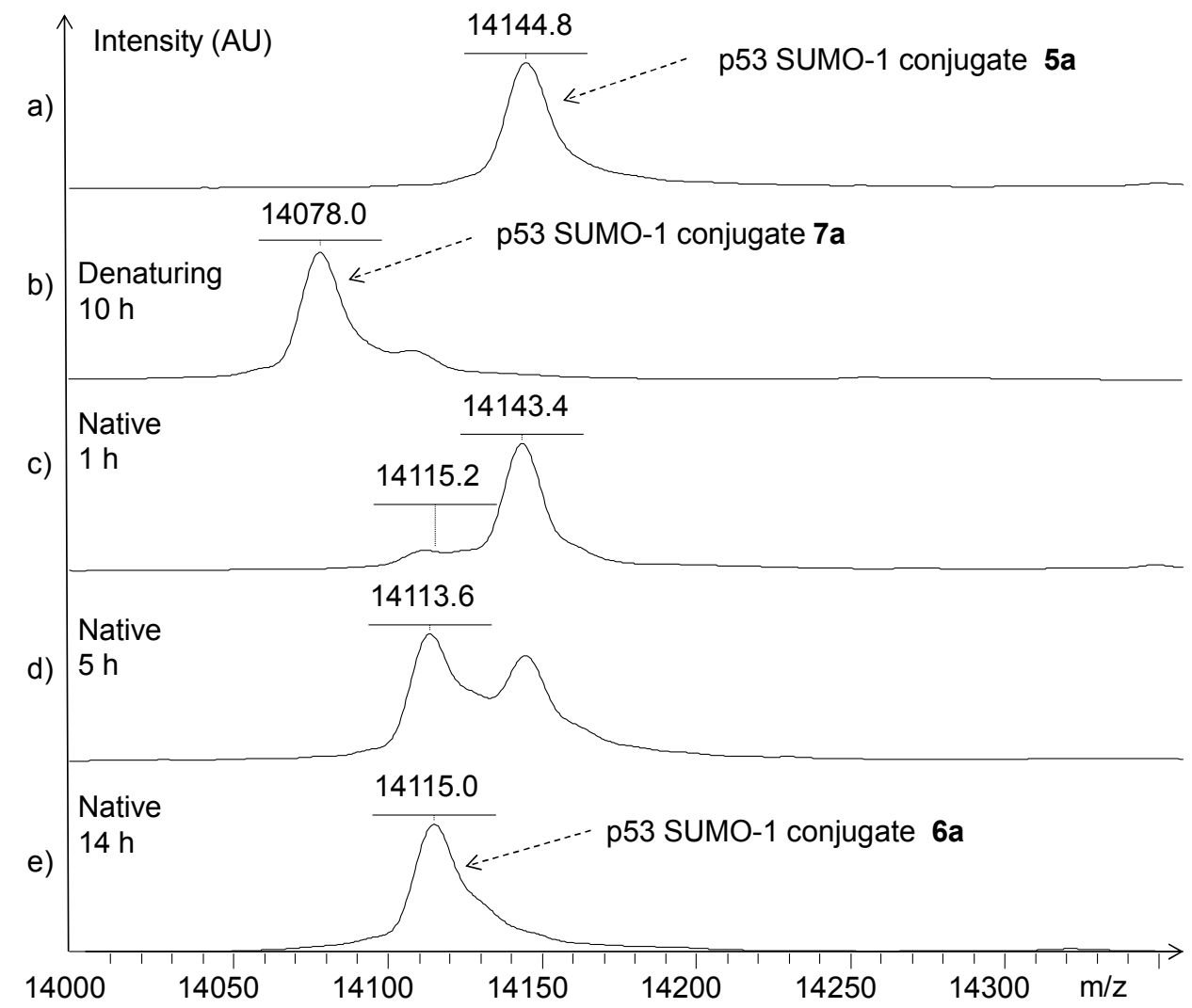

Figure S10. Desulfurization of synthetic p53 SUMO-1 conjugate 5a (VA-044 $1.33 \mathrm{mM}$, TCEP $200 \mathrm{mM}$, GSH $20 \mathrm{mM}, 25^{\circ} \mathrm{C}, \mathrm{pH} 7.2$ ). MALDI-TOF analysis of the desulfurization reaction using sinapinic acid as matrix (a: starting conjugate $5 \mathrm{a}, \mathrm{b}$ : $6 \mathrm{M} \mathrm{Gdn}$. $\mathrm{HCl}$, c-e: native conditions). 


\section{Characterization of conjugate $6 a$}

SDQEAKPSTEDLGDKKEGEYIKLKVIGQDSSEIHFKVKMTTHLKKLKESYCQRQGVPMNSLRFLFEGQRIADNHTPKELGMEEEDVIEVYYEQTG

A)

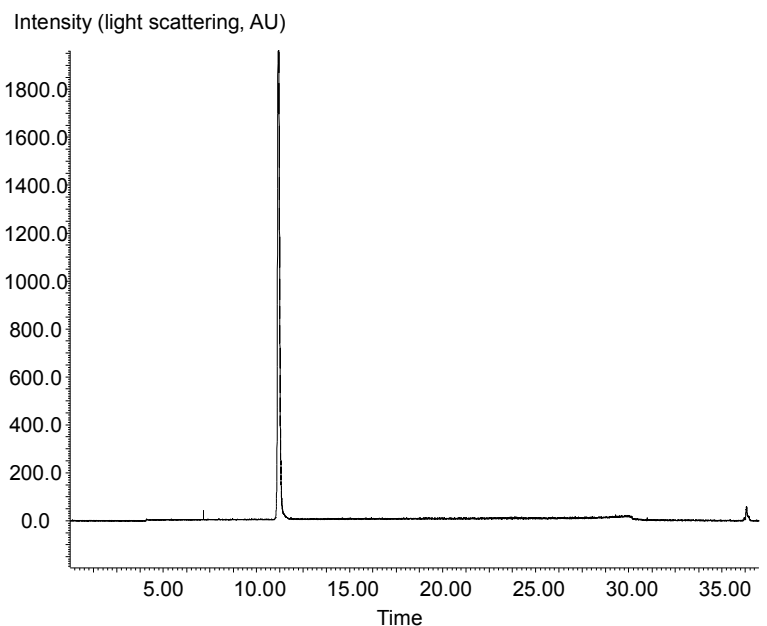

B)

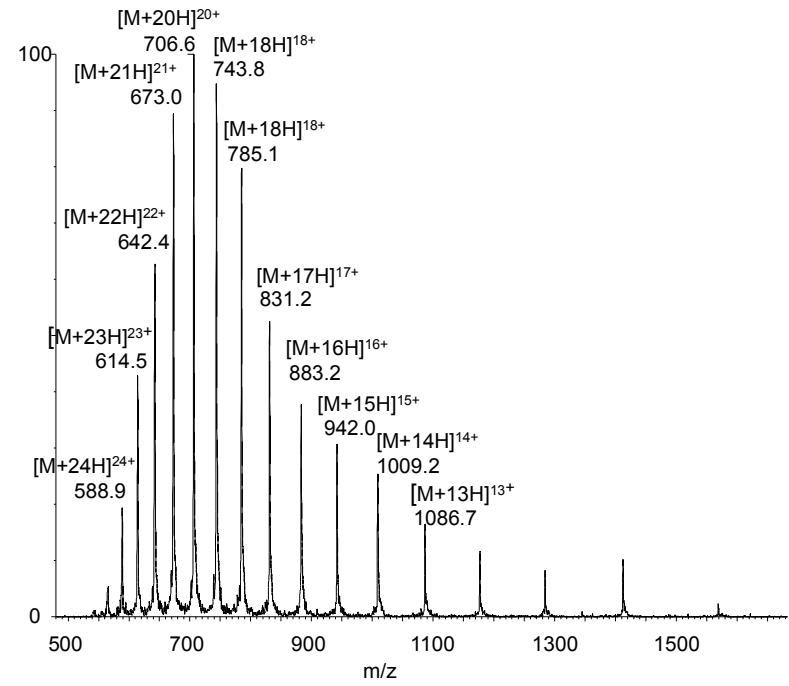


C)

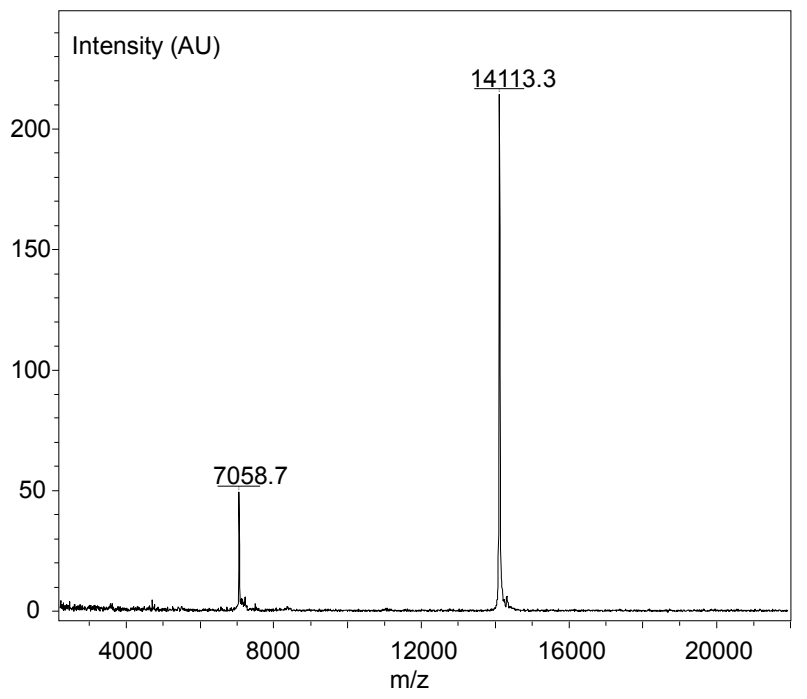

D)

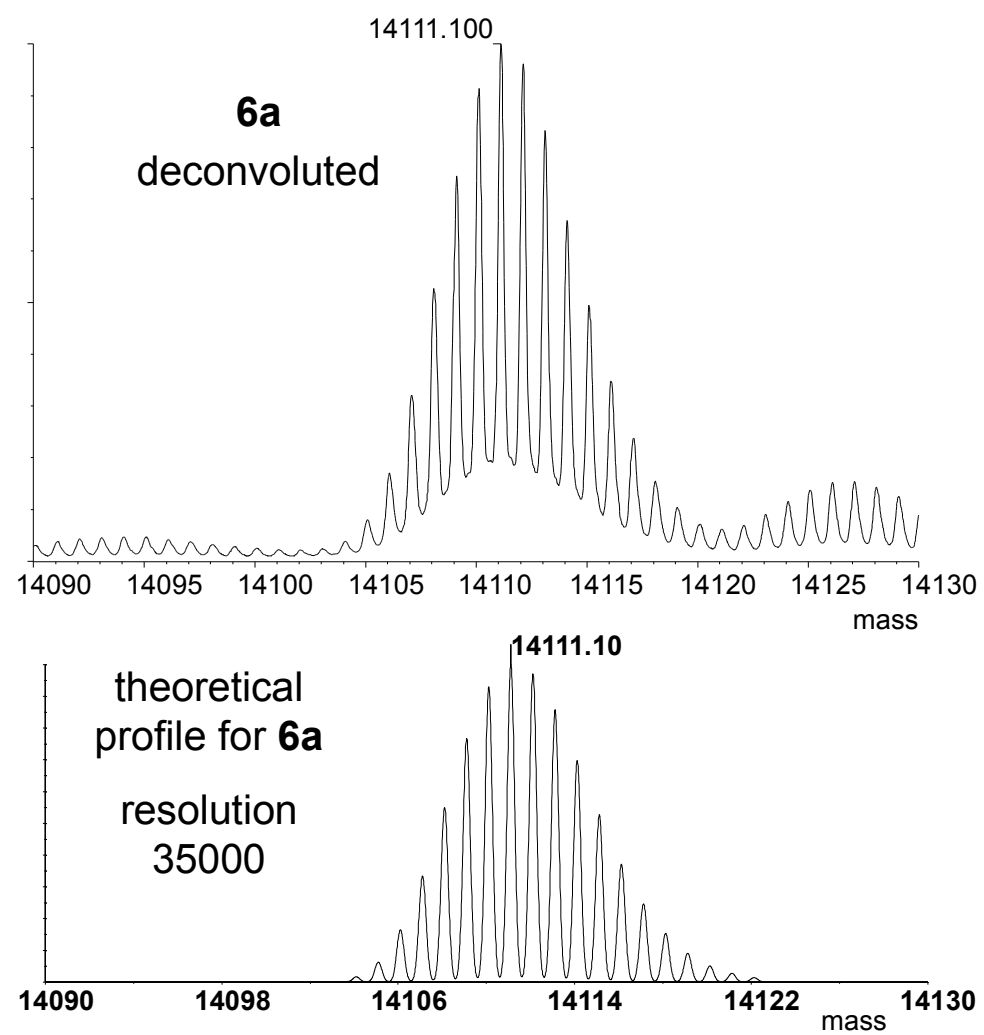

Figure S11. Analysis of p53 SUMO-1 conjugate 6a. A) LC-MS analysis, HPLC trace (light scattering detection). ). C3 Zorbax column ( $5 \mu \mathrm{m}, 300 \AA$, $9.4 \times 250 \mathrm{~mm}$, Agilent), $50{ }^{\circ} \mathrm{C}$. Flow $1 \mathrm{~mL} / \mathrm{min}$, eluent $\mathrm{A}$ $0.1 \%$ formic acid in water, eluent B $0.1 \%$ formic acid in $80 \%$ aqueous acetonitrile. Gradient from $0 \%$ buffer B to $100 \%$ buffer B in 30 min. B) MS trace, calculated for M (average mass) 14111.91 observed 
14112.66 after deconvolution. C) MALDI-TOF analysis. Matrix: sinapinic acid. Calculated for $[\mathrm{M}+\mathrm{H}]^{+}$ (average mass) 14112.8, observed 14113.3 (linear positive mode).D) HRMS analysis, reconstructed mass compared with the theoretical profile for $\mathrm{C}_{611} \mathrm{H}_{984} \mathrm{~N}_{174} \mathrm{O}_{199} \mathrm{~S}_{5}$ at resolution 35000 .

MALDI-TOF in source fragmentation of p53 SUMO-1 conjugate 6a. Proof of structure

A)

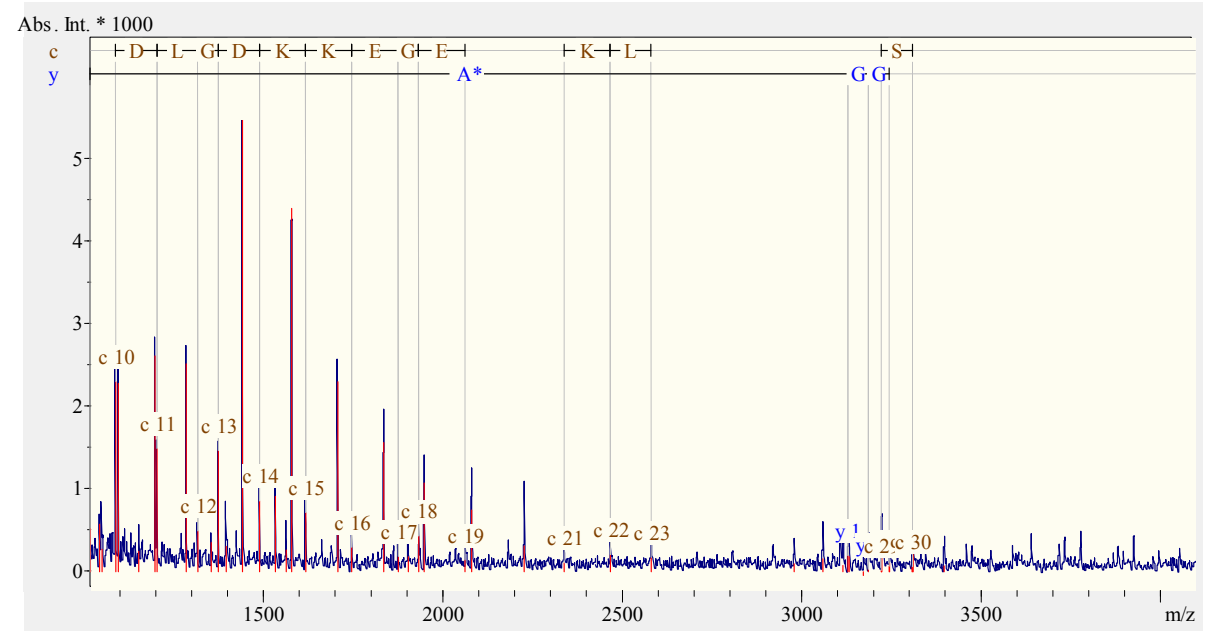

B)

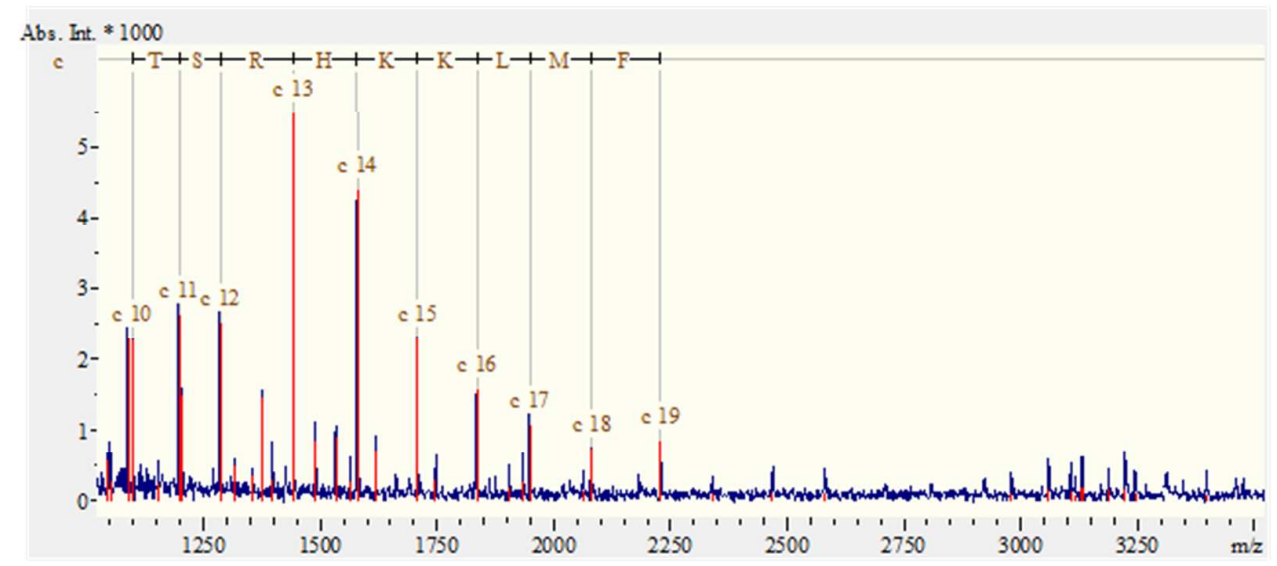


C)

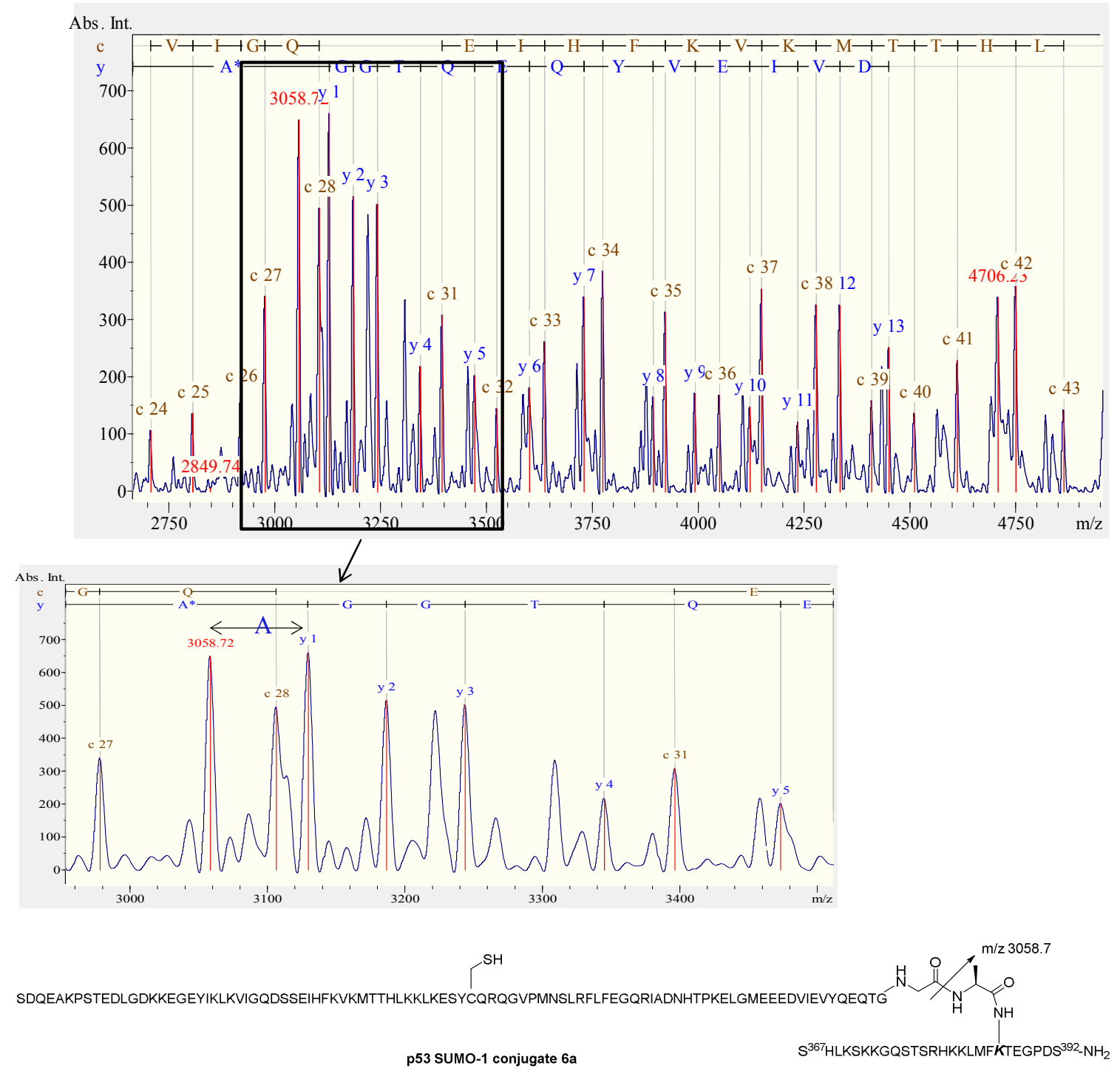

Figure S12. In source MALDI-TOF sequencing of conjugate 6a using 2,5-dihydroxybenzoic acid as matrix (positive reflector mode). $\mathrm{C}$ ions corresponding to the N-terminal part of SUMO-1 domain (A) or target peptide (B) could be identified. Importantly, the y ions detected in (C) show the formation of the peptide bond between the C-terminal Ala residue of SUMO-1 protein and the target peptide (D). $A^{*}$ is for the $y$ ion at $\mathrm{m} / \mathrm{z}$ which corresponds to the $\mathrm{p} 53$ peptide plus the $\mathrm{C}$-terminal Ala residue. 
Desulfurization of conjugate $5 \mathrm{a}$ in denaturing conditions. Preparation of $7 \mathrm{a}$

SDQEAKPSTEDLGDKKEGEYIKLKVIGQDSSEIHFKVKMTTHLKKLKESYAQRQGVPMNSLRFLFEGQRIADNHTPKELGMEEEDVIEVYQEQTG

Peptide 5a $(50 \mu \mathrm{g})$ was dissolved in $6 \mathrm{M} \mathrm{Gdn} . \mathrm{HCl} 0.1 \mathrm{M} \mathrm{pH} 7.2$ ammonium phosphate buffer containing TCEP ( $200 \mathrm{mM}$ final concentration), VA-044 (1.33 mM final concentration) and GSH (20 $\mathrm{mM}$ final concentration). The desulfurization was carried out at $25{ }^{\circ} \mathrm{C}$ and monitored by MALDI-TOF mass spectrometry. After $10 \mathrm{~h}$, conjugate $7 \mathrm{a}$ was desalted by HPLC and subjected to alkylation/enzymatic digestion for MS analysis.

Alkylation of 5a, $6 a$ and $7 a$ with iodoacetamide, enzymatic cleavage and analysis of the peptide fragments by MALDI-TOF MS or LC-MS

The conjugates $\mathbf{5 a}, \mathbf{6 a}$ and $\mathbf{7 a}$ (fully desulfurized conjugate from $5 \mathrm{a})(\sim 20 \mu \mathrm{g})$ were alkylated with iodoacetamide ( $20 \mu \mathrm{L}, 1 \mathrm{mg} / \mathrm{mL}$ in $6 \mathrm{M} \mathrm{Gdn} . \mathrm{HCl} 0.1 \mathrm{M} \mathrm{pH} 7.2$ ammonium phosphate buffer) for 30 min at $25^{\circ} \mathrm{C}$. The alkylation step was monitored by MALDI-TOF mass spectrometry as shown below. This experiment shows that the conjugate $\mathbf{5 a}$ is dialkylated, while the conjugate $\mathbf{6 a}$ is monoalkylated. As expected, conjugate $7 a$ resulting from the desulfurization in denaturing conditions was not alkylated.

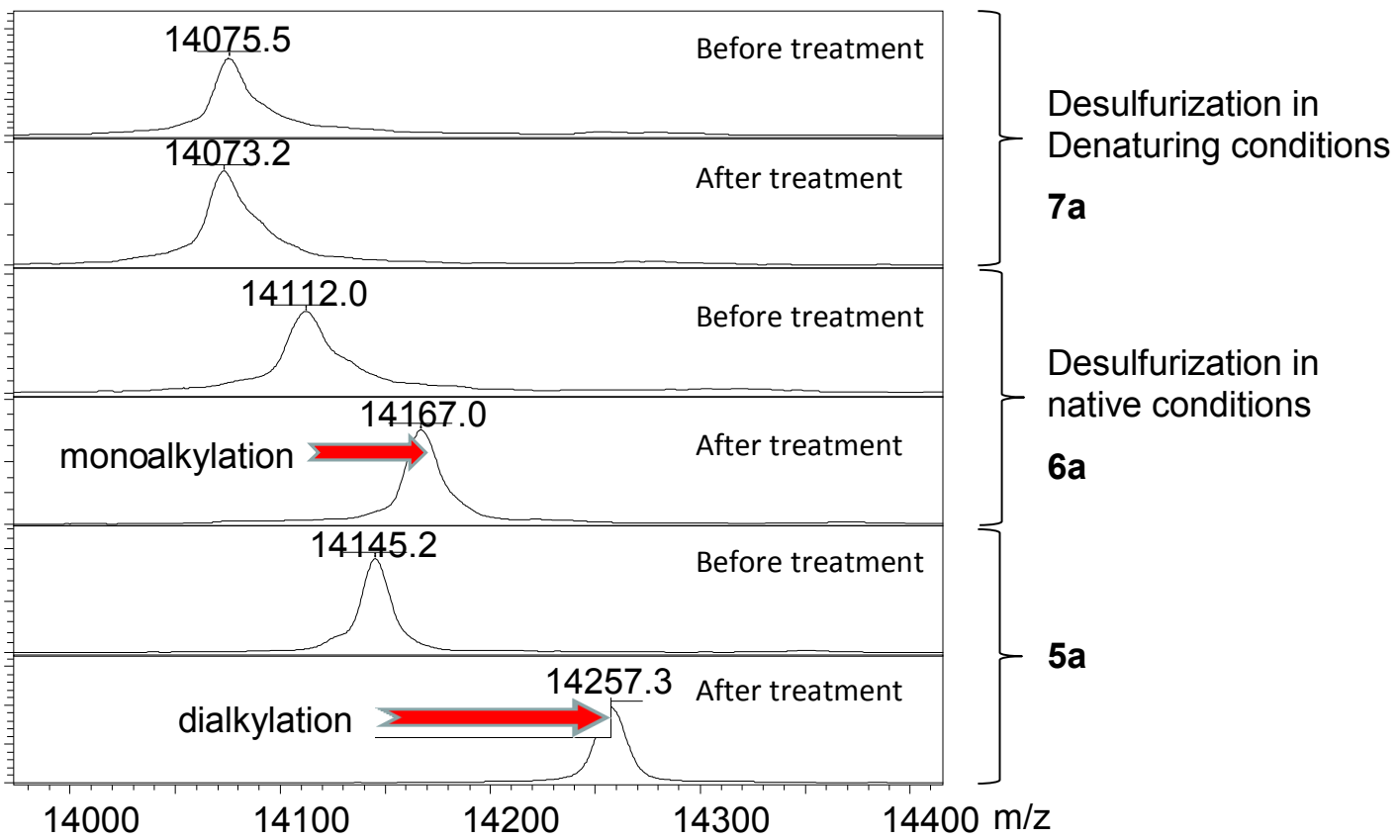

Figure S13. Monitoring of the alkylation step by MALDI-TOF mass spectrometry (matrix: sinapinic acid). This experiment shows that the conjugate $7 \mathbf{a}$ obtained by desulfurization in denaturing conditions is not alkylated due to the absence of thiol groups, while conjugate 6 a obtained by desulfurization in native conditions is only alkylated once (no peak at m/z 14075 was observed that 
could be due to a lack of selectivity during the desulfurization step). The control experiment with conjugate 5 a results in the incorporation of two carbamidomethyl groups, as expected.

The samples were subsequently diluted tenfold with $0.1 \mathrm{M} \mathrm{pH} 7.2$ ammonium phosphate buffer and digested overnight at room temperature with of EndoGluC protease (Staphylococcus aureus protease V8, $1 \mu \mathrm{g}, 5 \%$ by weight). The formed peptide fragments were analyzed by MALDI-TOF MS and LC-MS.

A)

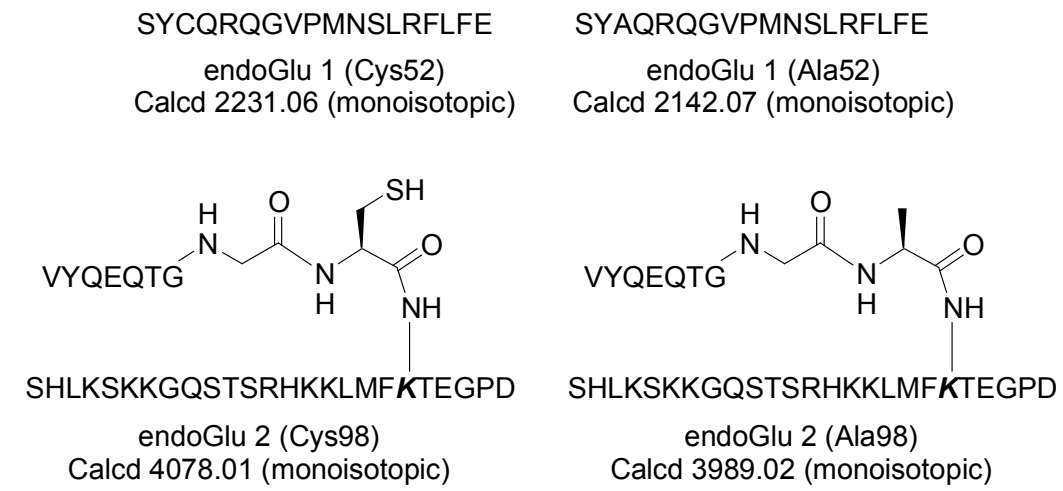

D)

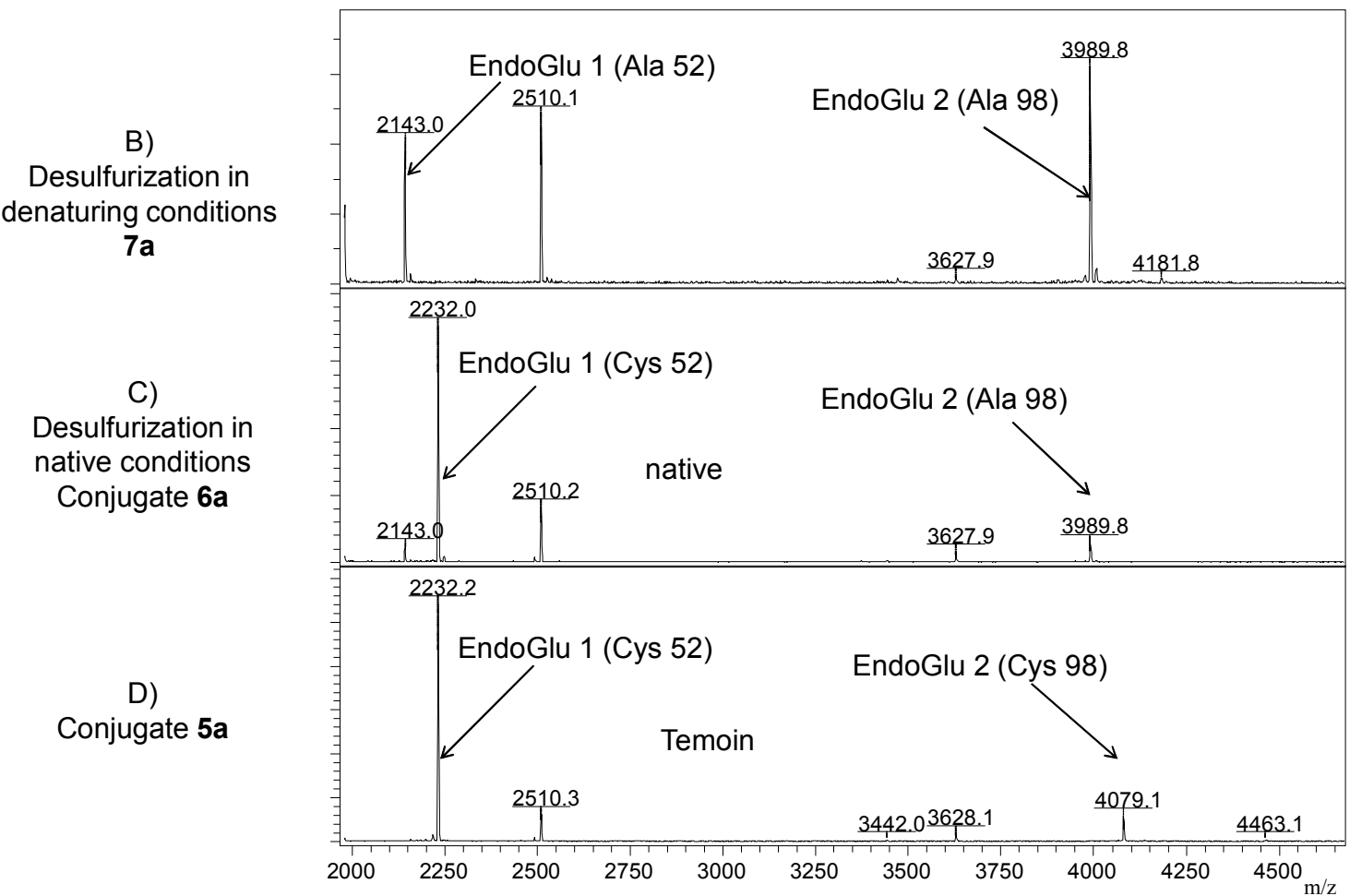

Figure S14. Analysis of the EndoGluC protease digest by MALDI-TOF mass spectrometry (matrix: alpha cyanno). Two types of peptide fragments were identified that allow documenting the presence 
of a Cys residue (or Ala) at position 52 within the SUMO-1 domain, and 98 in the linker region between SUMO-1 and the p53 peptide (A). The conjugate 7a produced by desulfurization in denaturing conditions showed an Ala residue in both positions (B), while the conjugate 6a produced by desulfurization in native conditions showed a Cys residue in position 52, and an Ala residue in position 98 (C). We noticed also in Fig S12C the presence of a minor peak at $\mathrm{m} / \mathrm{z} 2143$ showing that a small proportion of Cys52 is nevertheless converted into Ala52. In the control experiment with conjugate 5a, Cys was found at both positions, as expected (D).

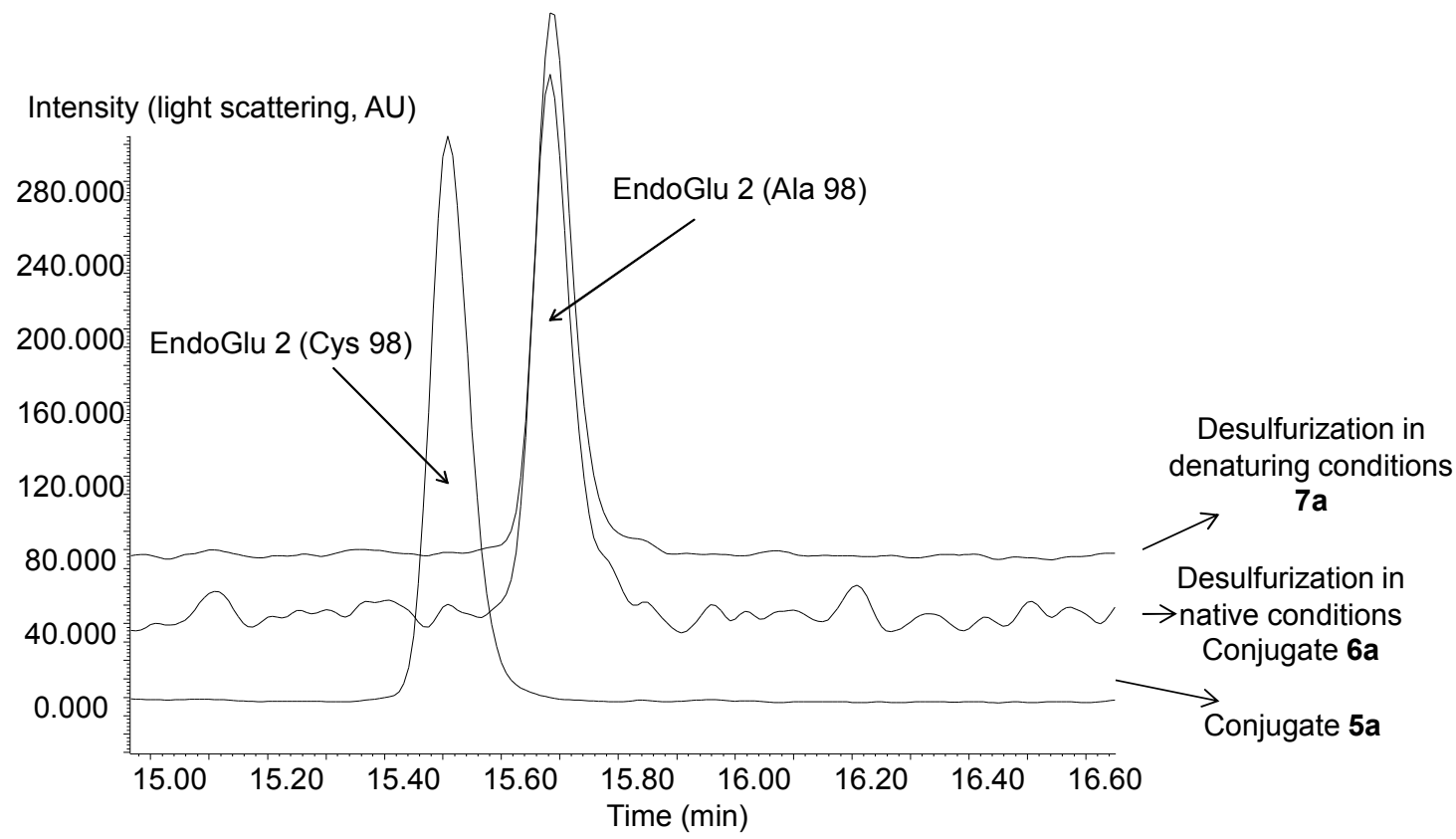

Figure S15. Analysis of the EndoGluC protease digests by LC-MS. EndoGlu 2 fragments corresponding to the linker region between SUMO-1 domain and p53 peptide. LC-MS analysis, HPLC trace (light scattering detection). Column xBridge ${ }^{\mathrm{tm}} \mathrm{BEH} 300 \mathrm{C} 18\left(3.5 \mu \mathrm{m}, 300 \AA, 4.6 \times 150 \mathrm{~mm}\right.$, Agilent), $50{ }^{\circ} \mathrm{C}$. Flow $1 \mathrm{~mL} / \mathrm{min}$, eluent $A 0.1 \%$ trifluoroacetic acid in water, eluent $B 0.1 \%$ trifluoroacetic acid in $80 \%$ aqueous acetonitrile. Gradient from $0 \%$ buffer B to $50 \%$ buffer B in 30 min. 


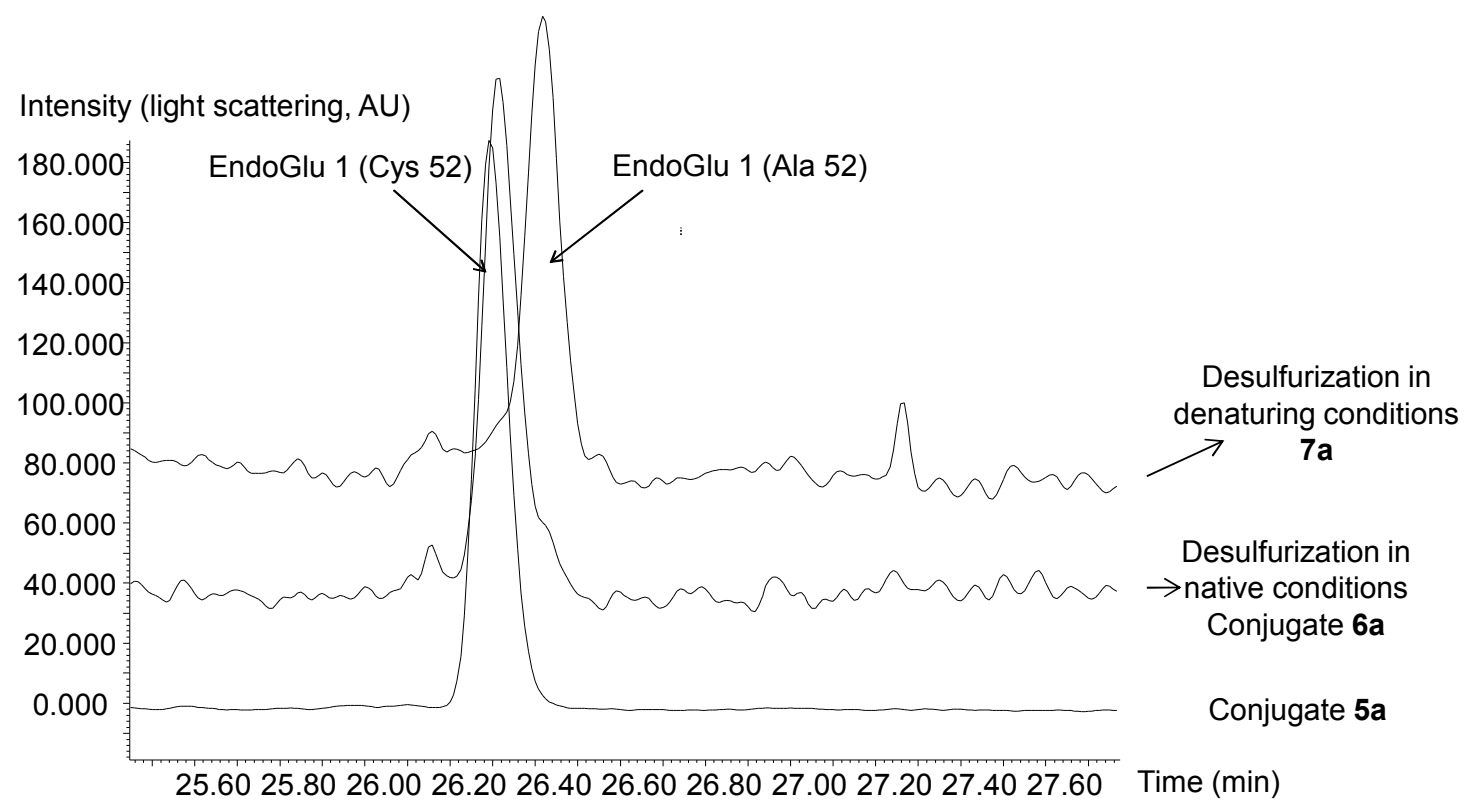

Figure S16. Analysis of the EndoGluC protease digests by LC-MS. EndoGlu 1 fragments corresponding to the central region of the SUMO-1 domain. These chromatograms confirm the selectivity of the desulfurization reaction in native conditions. The EndoGlu 1 (Ala52) fragment that has been detected in Fig. S12C (desulfurization in native conditions, conjugate $\mathbf{5 c}$ ) is barely detected. LC-MS analysis, HPLC trace (light scattering detection). Column xBridge ${ }^{\mathrm{tm}}$ BEH300 C18 $(3.5 \mu \mathrm{m}, 300 \AA ̊ 丿, 4.6 \times 150 \mathrm{~mm}$, Agilent), $50{ }^{\circ} \mathrm{C}$. Flow $1 \mathrm{~mL} / \mathrm{min}$, eluent $A 0.1 \%$ trifluoroacetic acid in water, eluent $B \quad 0.1 \%$ trifluoroacetic acid in $80 \%$ aqueous acetonitrile. Gradient from $0 \%$ buffer B to $50 \%$ buffer B in 30 min.

\section{Synthesis of conjugate $6 b$ by selective desulfurization of conjugate $5 b$}

\section{Desulfurization of conjugate $5 b$ in native conditions}

Conjugate $5 \mathbf{b}$ (1.15 mg, $0.67 \mu \mathrm{mol}, 0.58 \mathrm{mM}$ final concentration) was dissolved in a solution of TCEP (57.31 $\mathrm{mg} / \mathrm{mL}, \quad 200 \mathrm{mM}$ final concentration), 2,2'-azobis[2-(2-imidazolin-2-yl)propane]dihydrochloride (VA-044, $0.43 \mathrm{mg} / \mathrm{mL}, 1.33 \mathrm{mM}$ final concentration) and reduced glutathione (30.7 $\mathrm{mg} / \mathrm{mL}, 100 \mathrm{mM}$ final concentration) in $0.1 \mathrm{M} \mathrm{pH} 7.2$ ammonium phosphate buffer (1.15 mL). The desulfurization was carried out at $25^{\circ} \mathrm{C}$ and monitored by MALDI-TOF mass spectrometry.

After $30 \mathrm{~h}$, the reaction product was purified by HPLC to yield $0.94 \mathrm{mg}$ ( $80 \%$ yield) of pure conjugate 6b.

HPLC conditions: C3 Zorbax column ( $5 \mu \mathrm{m}, 300 \AA, 9.4 \times 250 \mathrm{~mm}$, Agilent), $50{ }^{\circ} \mathrm{C}$, detection at $215 \mathrm{~nm}$, flow rate $6 \mathrm{~mL} / \mathrm{min}$, eluent $A 0.1 \%$ trifluoroacetic acid in water, eluent $B 0.1 \%$ trifluoroacetic acid in $80 \%$ aqueous acetonitrile. Gradient from $20 \%$ buffer B to $40 \%$ buffer B in 60 min. 


\section{Characterization of conjugate $6 \mathrm{~b}$}

A)

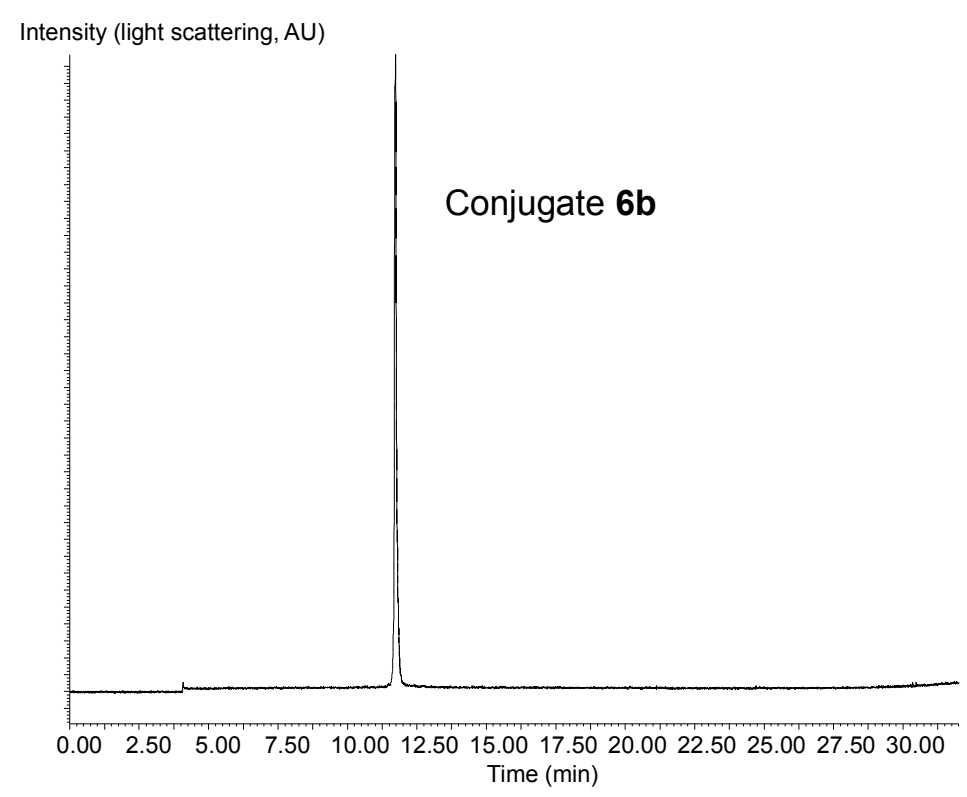

B)

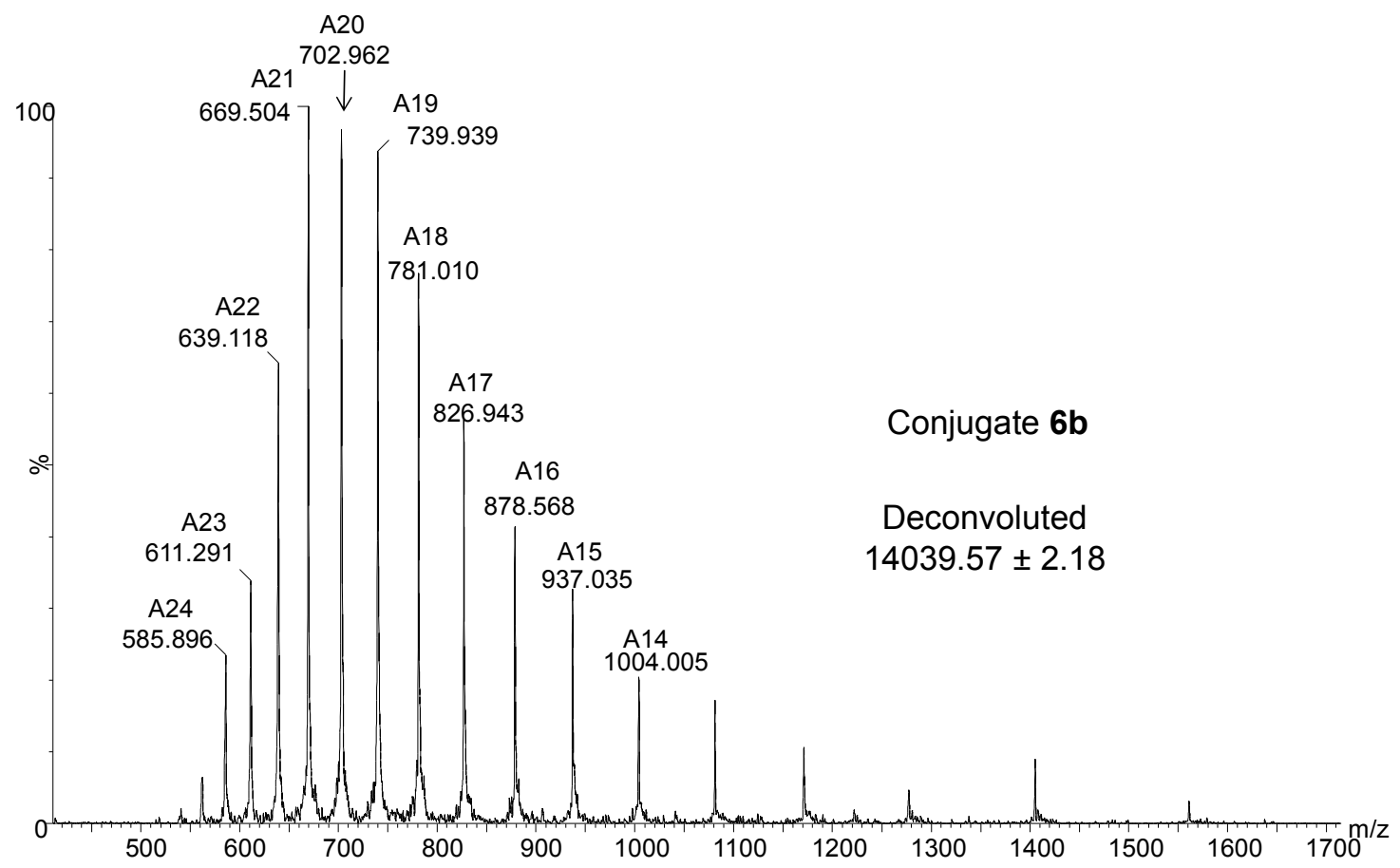


C)

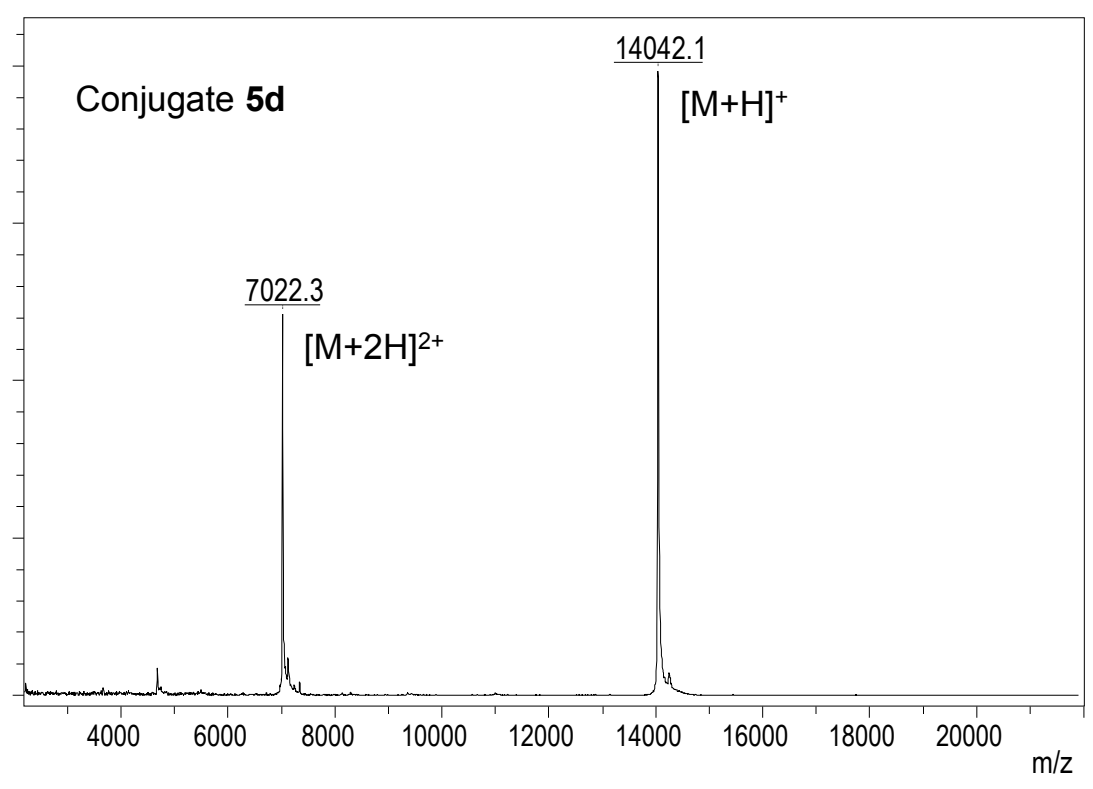

D)

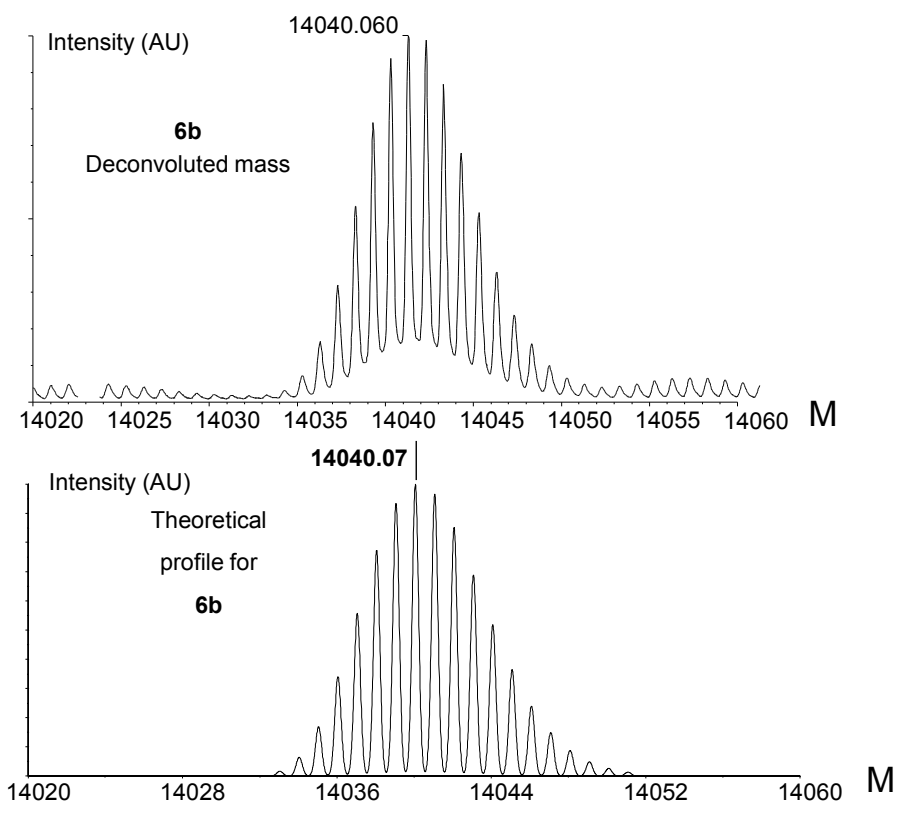

Figure S17. Analysis of p53 SUMO-1 conjugate 6b. A) LC-MS analysis, HPLC trace (light scattering detection). Zorbax C3 $(5 \mu \mathrm{m}, 4.6 \mathrm{~mm} \times 150 \mathrm{~mm}), 50{ }^{\circ} \mathrm{C}$. Flow $1 \mathrm{~mL} / \mathrm{min}$, eluent $\mathrm{A} 0.1 \%$ formic acid in water, eluent B $0.1 \%$ formic acid in $80 \%$ aqueous acetonitrile. Gradient from $0 \%$ buffer B to $50 \%$ buffer B in 30 min. B) MS trace, calculated for [M] (average mass) 14040.64, observed 14039.57+/2.2 after deconvolution. C) MALDI-TOF analysis. Matrix: sinapinic acid, calculated for $[\mathrm{M}+\mathrm{H}]^{+}$(average 
mass) 14041.64, observed 14042.1. D) HRMS analysis, reconstructed mass compared with theoretical profile for $\mathrm{C}_{608} \mathrm{H}_{979} \mathrm{~N}_{173} \mathrm{O}_{198} \mathrm{~S}_{5}$ at resolution 35000 .

MALDI-TOF in source fragmentation of p53 SUMO-1 conjugate 6b. Proof of structure

A)

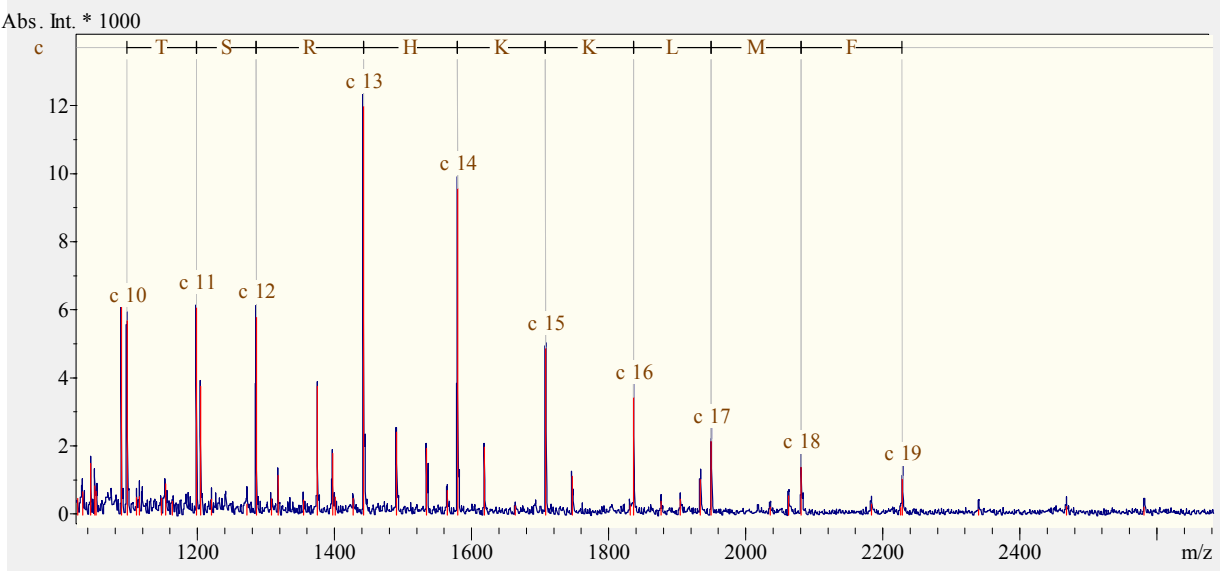


B)
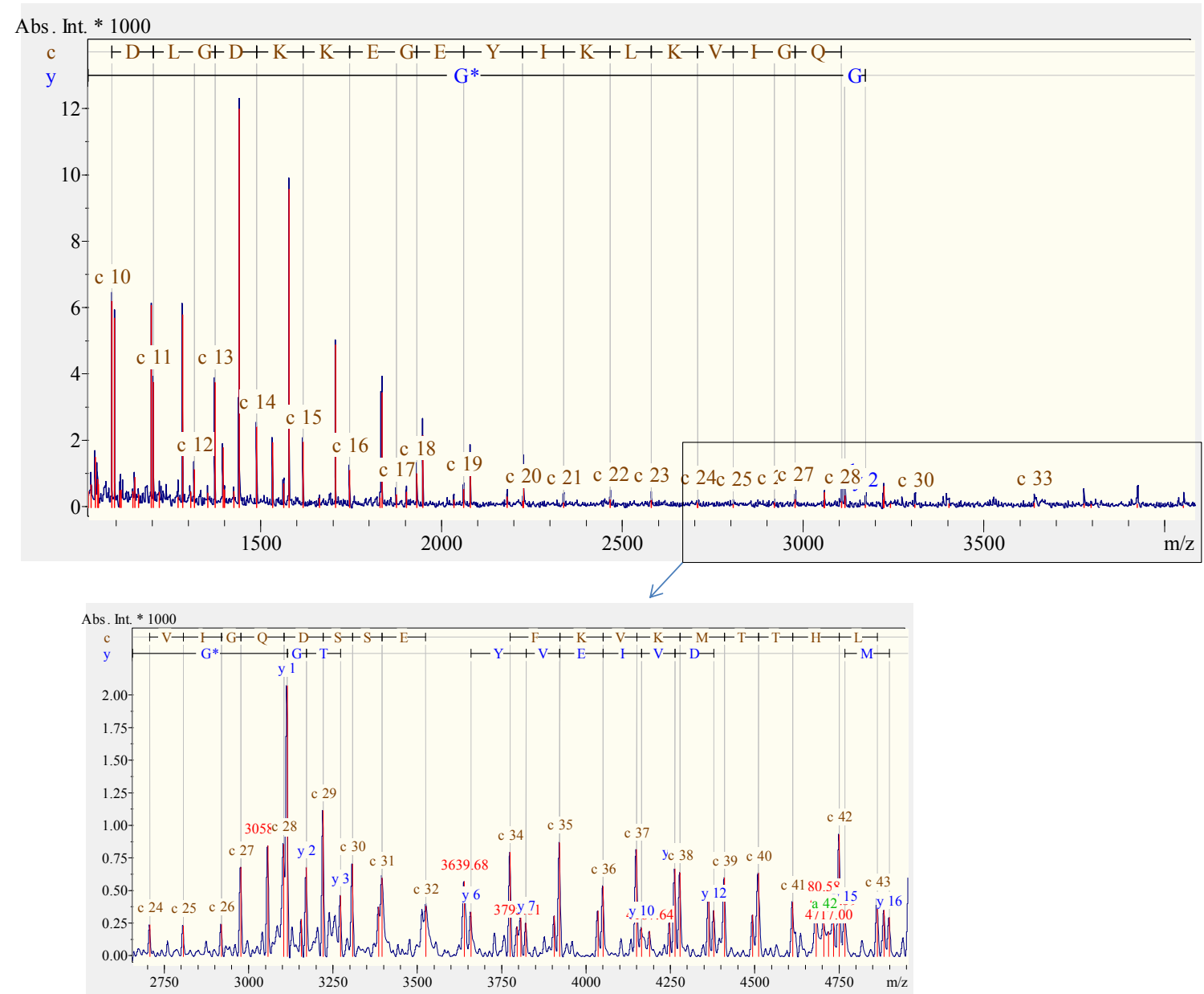

C)

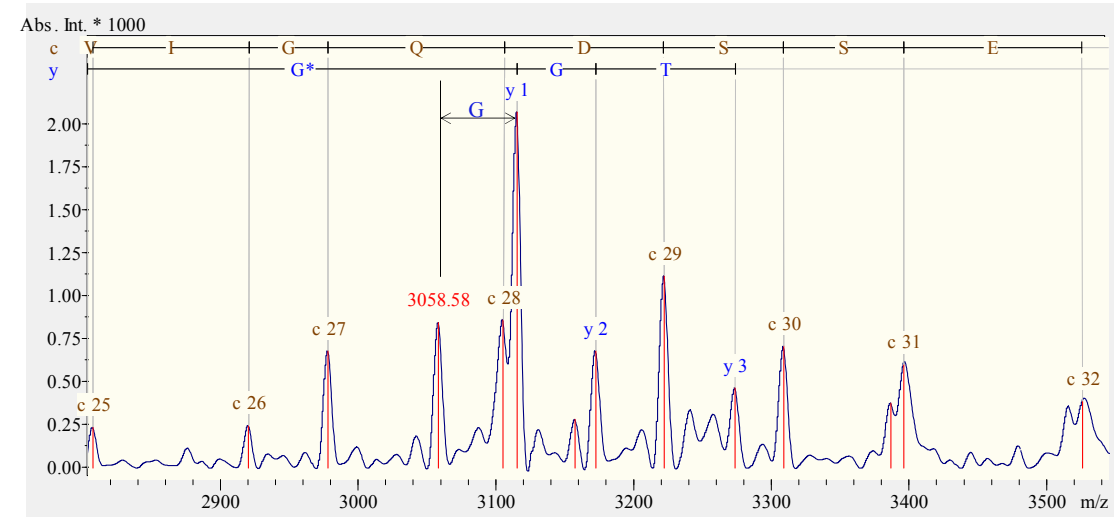


D)

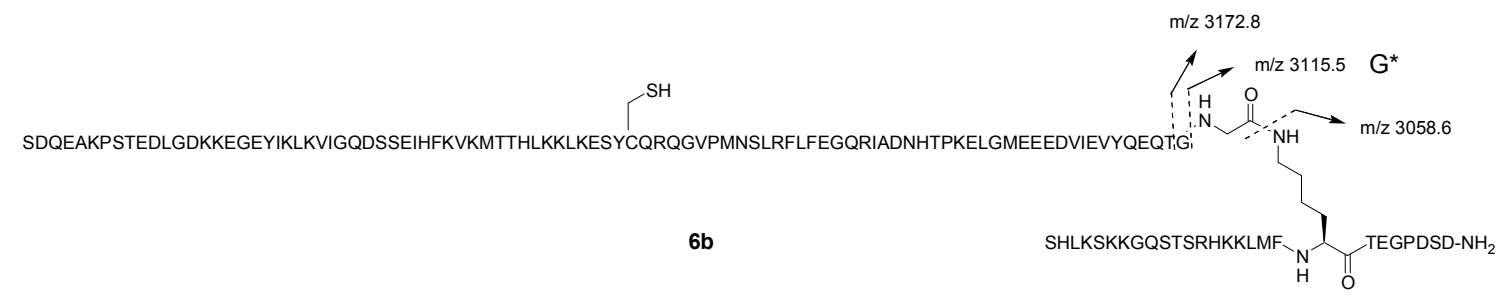

Figure S18. In source MALDI-TOF sequencing of conjugate $\mathbf{6 b}$ using 2,5-dihydroxybenzoic acid as matrix (positive reflector mode). lons corresponding to the $\mathrm{N}$-terminal part of target p53 peptide (A) or SUMO-1 domain (B) could be identified. The ions found in (C) show the formation of the peptide bond between the C-terminal Gly residue of SUMO-1 protein and the Lys 20 residue of the target p53peptide. $G^{*}$ is for the $y$ ion at $\mathrm{m} / \mathrm{z}$ which corresponds to the $\mathrm{p} 53$ peptide plus the C-terminal Gly residue (D).

\section{Alkylation of conjugates $5 \mathrm{~b}$ and $6 \mathrm{~b}$ with iodoacetamide, enzymatic cleavage and analysis of the peptide fragments by MALDI-TOF MS or LC-MS}

The conjugates $(\sim 20 \mu \mathrm{g})$ were treated with iodoacetamide $(20 \mu \mathrm{L}, 1 \mathrm{mg} / \mathrm{mL}$ in $6 \mathrm{M} \mathrm{Gdn} . \mathrm{HCl} 0.1 \mathrm{M} \mathrm{pH}$ 7.2 ammonium phosphate buffer) for $30 \mathrm{~min}$ at $25^{\circ} \mathrm{C}$. The alkylation step was monitored by MALDITOF mass spectrometry as shown below. This experiment shows that conjugate $\mathbf{5 b}$ is dialkylated, while the conjugate $\mathbf{6} \mathbf{b}$ obtained by selective desulfurization is monoalkylated.

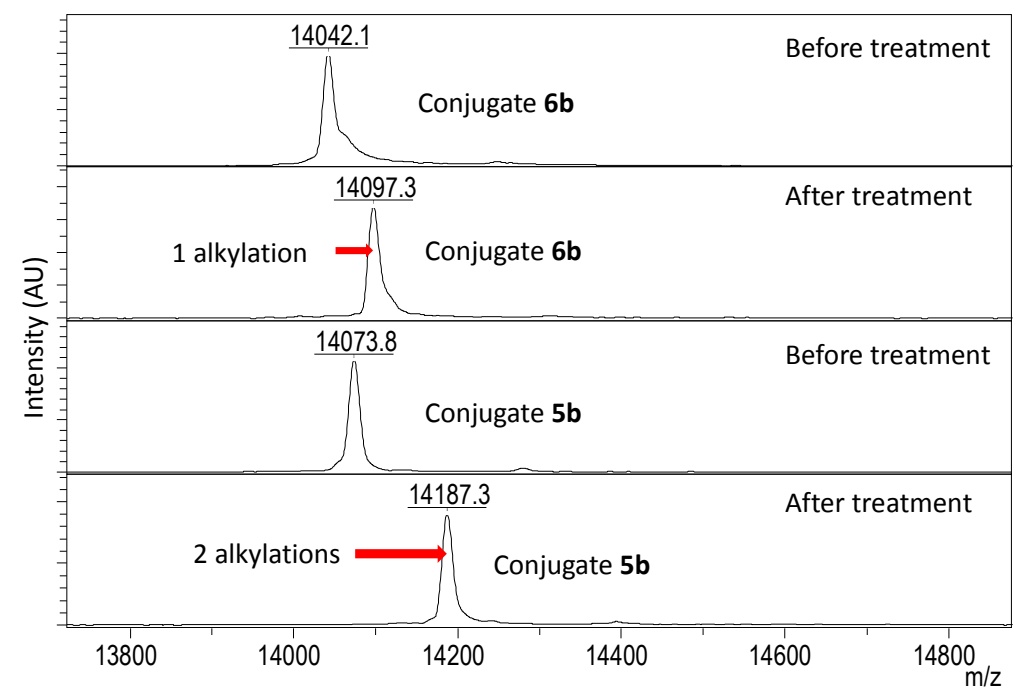

Figure S19. Monitoring of the alkylation step by MALDI-TOF mass spectrometry (matrix: sinapinic acid). This experiment shows that the conjugate $\mathbf{6} \mathbf{b}$ obtained by selective desulfurization in native conditions is only alkylated once (no peak at m/z 14151 was observed that could be due to a lack of 
selectivity). The control experiment with conjugate $\mathbf{5 b}$ results in the incorporation of two carbamidomethyl groups, as expected.

The alkylated samples were subsequently diluted tenfold with $0.1 \mathrm{M} \mathrm{pH} 7.2$ ammonium phosphate buffer and digested with EndoGluC protease (Staphylococcus aureus protease V8, $1 \mu \mathrm{g}, 5 \% \mathrm{w} / \mathrm{w}$ ) overnight at room temperature. The formed peptide fragments were identified by MALDI-TOF MS and LC-MS.

A)

$\begin{array}{cc}\text { SYCQRQGVPMNSLRFLFE } & \text { SYAQRQGVPMNSLRFLFE } \\ \text { endoGlu 1 (Cys52) } & \text { endoGlu 1 (Ala52) } \\ \text { Calcd 2231.06 (monoisotopic) } & \text { Calcd 2142.07 (monoisotopic) }\end{array}$

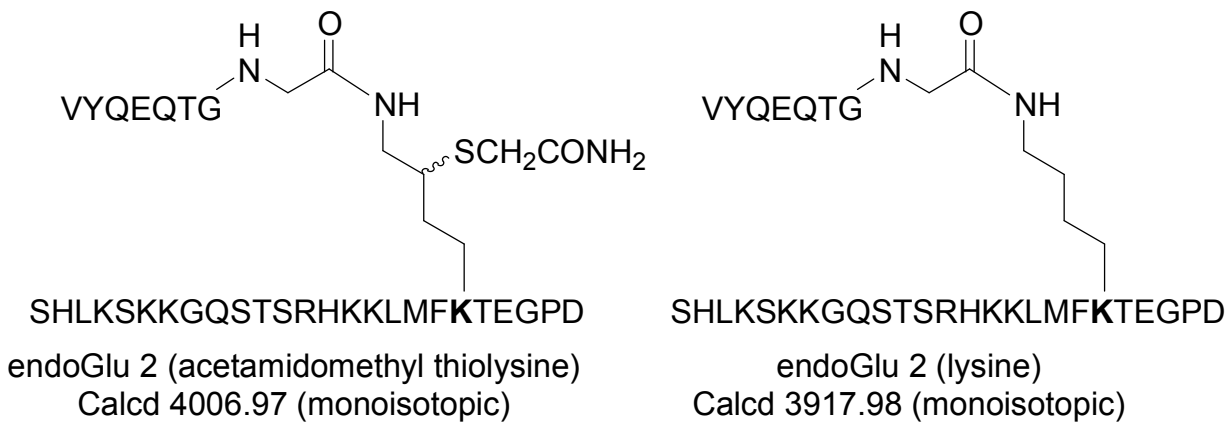

B)

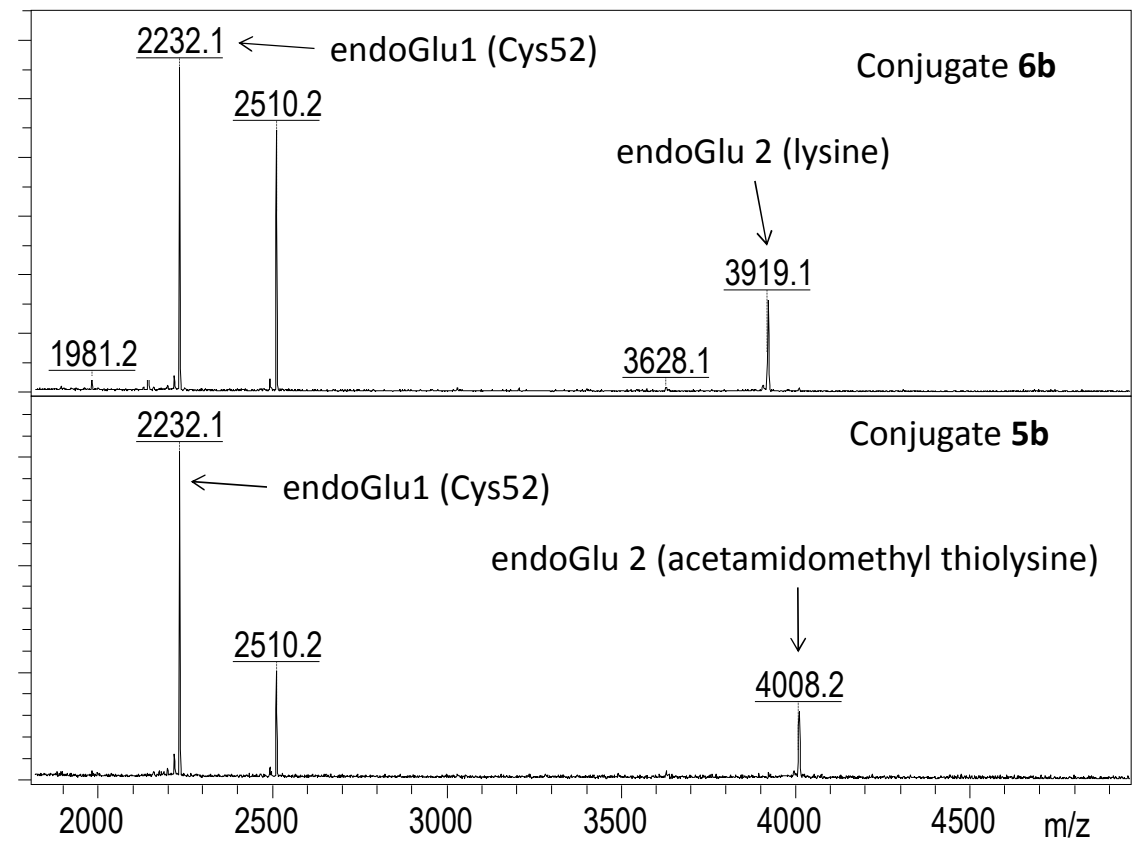


Figure S20. Analysis of the EndoGluC protease digests by MALDI-TOF mass spectrometry (matrix: alpha-cyano-4-hydroxy-cinnamic acid). Two types of peptide fragments were identified that allow documenting the presence of a Cys residue at position 52 within the SUMO-1 domain, and the presence of thiolysine or lysine at position 20 of the p53 peptide in $\mathbf{5 b}$ and $\mathbf{6 b}$ respectively (A). The conjugate $\mathbf{6 b}$ produced by selective desulfurization in native conditions showed a lysine residue in position 20, and an cysteine residue in position 52 (B).

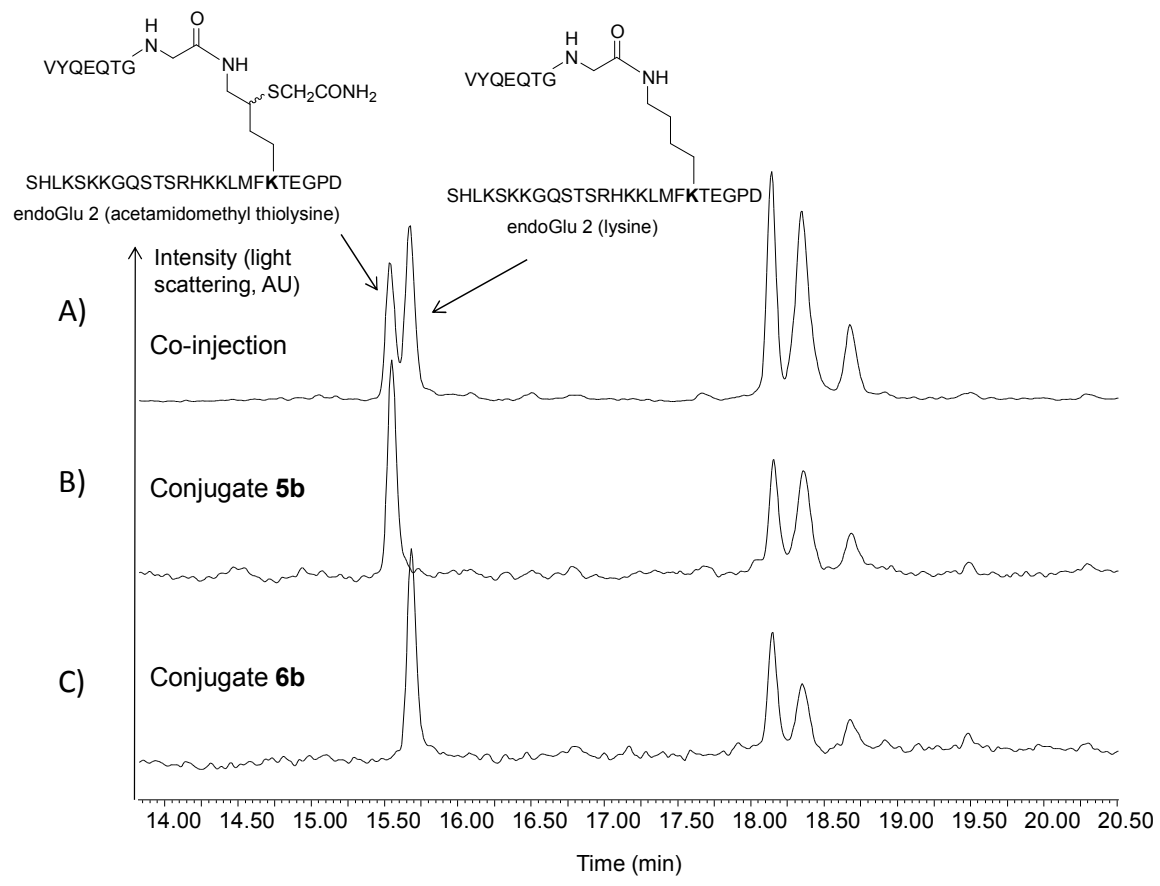

Figure S21. Analysis of the EndoGluC protease digests by LC-MS (p53 SUMO-1 conjugates $\mathbf{5 b}$ and $\mathbf{6 b}$ ). EndoGlu 2 fragments corresponding to the linker region between SUMO-1 domain and p53 peptide. LC-MS analysis, HPLC trace (light scattering detection). Column xBridge ${ }^{\mathrm{tm}}$ BEH300 C18 (3.5 $\mu \mathrm{m}, 300$ $\AA$, $4.6 \times 150 \mathrm{~mm}$, Agilent), $50{ }^{\circ} \mathrm{C}$. Flow $1 \mathrm{~mL} / \mathrm{min}$, eluent $\mathrm{A} 0.1 \%$ trifluoroacetic acid in water, eluent $\mathrm{B}$ $0.1 \%$ trifluoroacetic acid in $80 \%$ aqueous acetonitrile. Gradient from $0 \%$ buffer B to $50 \%$ buffer $B$ in $30 \mathrm{~min}$. 


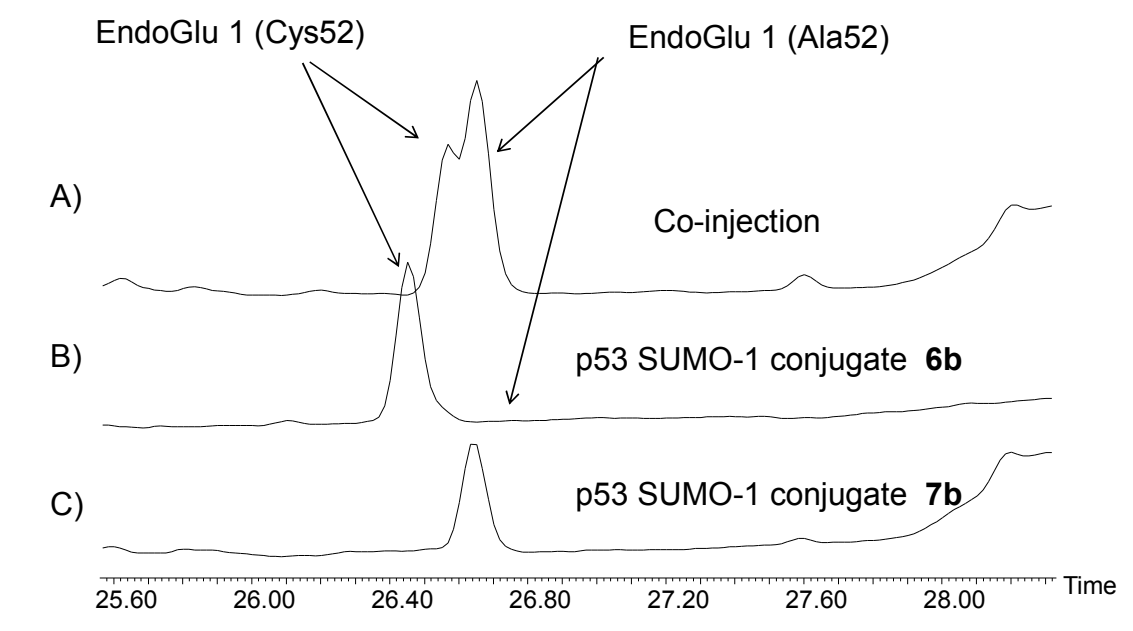

Figure S22. Analysis of the EndoGluC protease digests by LC-MS ( $p 53$ SUMO-1 conjugates $\mathbf{6 b}$ and $\mathbf{7 b}$ ). EndoGlu 1 fragments corresponding to the central region of the SUMO-1 domain. These chromatograms confirm the high selectivity of the desulfurization reaction in native conditions. 


\section{Preparation of SUMO-1 proteins 8 and 9}

The recombinant hSUMO-1 protein was purchased from Enzo life sciences (ref: ALX-201-045-C55).

The sequence of this protein is:

GSMSDQEAKPSTEDLGDKKEGEYIKLKVIGQDSSEIHFKVKMTTHLKKLKESYCQRQGVPMNSLRFLFEGQRIADNH

TPKELGMEEEDVIEVYQEQTGG

This protein corresponds to hSUMO-1 1-97 with an GS dipeptide extension at the $\mathrm{N}$-terminus.

\section{MALDI-TOF characterization of commercial hSUMO-1 (mixed disulfide with $\beta$-mercaptoethanol)}

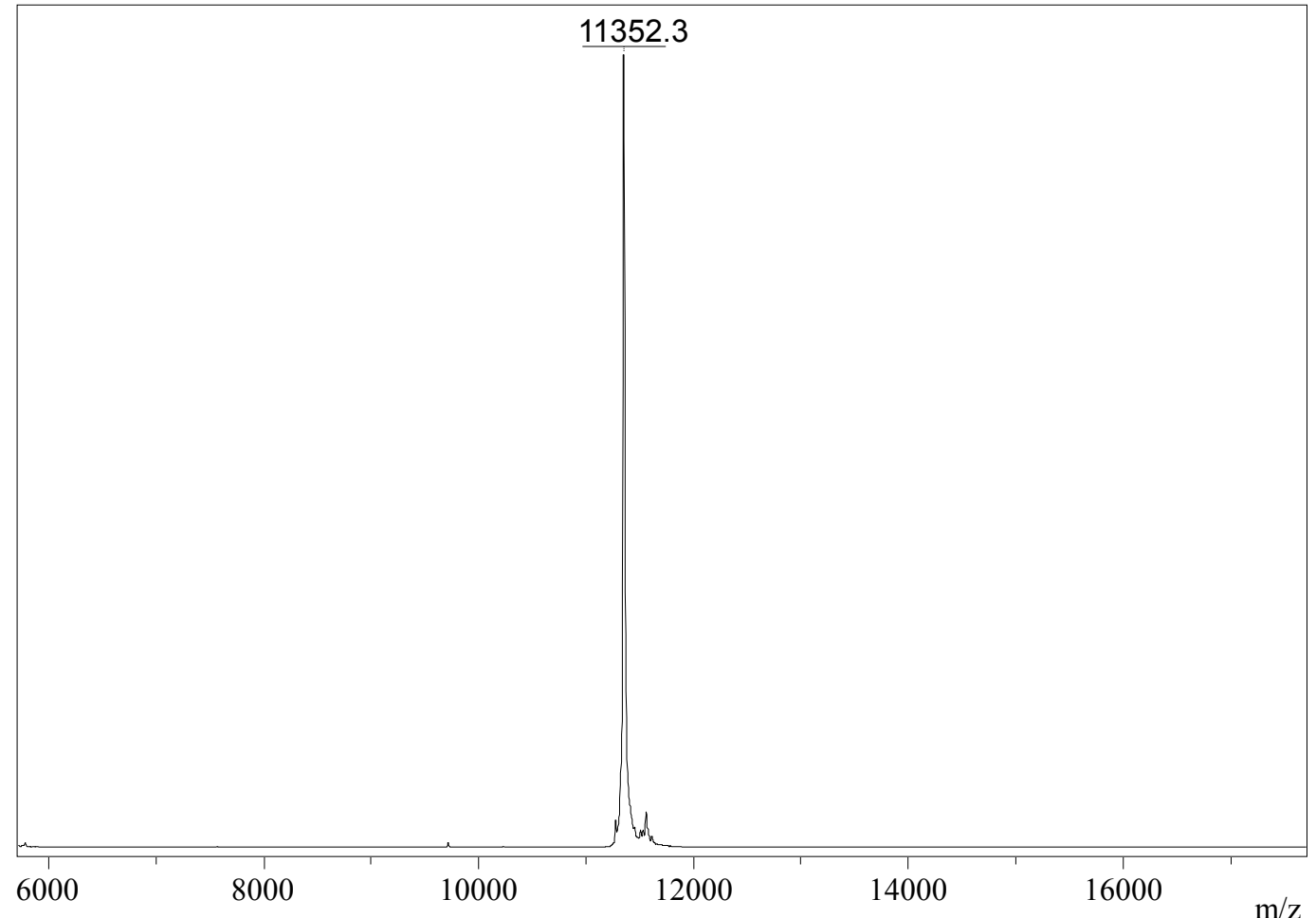

Fig. S23. MALDI-TOF analysis of commercial hSUMO-1. Matrix: sinapinic acid. Calculated for $[\mathrm{M}+\mathrm{H}]^{+}$ (average mass) 11353.7, observed 11352.3 (linear positive mode).

\section{Preparation of SUMO-1 protein 8}

Recombinant SUMO-1 protein $(500 \mu \mathrm{g})$ was dissolved in $6 \mathrm{M} \mathrm{Gdn.HCl} 0.1 \mathrm{M} \mathrm{pH} 7.2$ ammonium phosphate buffer containing TCEP $(0.5 \mathrm{mg} / \mathrm{mL}, 1.7 \mathrm{mM})$. The reaction was carried out at $25^{\circ} \mathrm{C}$ and monitored by MALDI-TOF mass spectrometry. After $1 \mathrm{~h}$, the sample was purified by RP-HPLC to yield $274 \mu \mathrm{g}(55 \%)$ of SUMO-1 protein 8.

Preparative HPLC conditions: XBridge BEH300 C18 (5 $\mu \mathrm{m}, 300 \AA, 10 \times 300 \mathrm{~mm})$ column, eluent A water containing $0.1 \%$ of TFA, eluent $\mathrm{B} \mathrm{CH}_{3} \mathrm{CN} /$ water : $4 / 1$ by vol containing $0.1 \%$ of TFA, gradient: 0 $100 \% \mathrm{~B}$ in $10 \mathrm{~min}$, flow rate $6 \mathrm{~mL} / \mathrm{min}$, UV detection at $215 \mathrm{~nm}, 50^{\circ} \mathrm{C}$. The purified fractions were pooled, frozen at $-20^{\circ} \mathrm{C}$ and lyophilized. 
A)

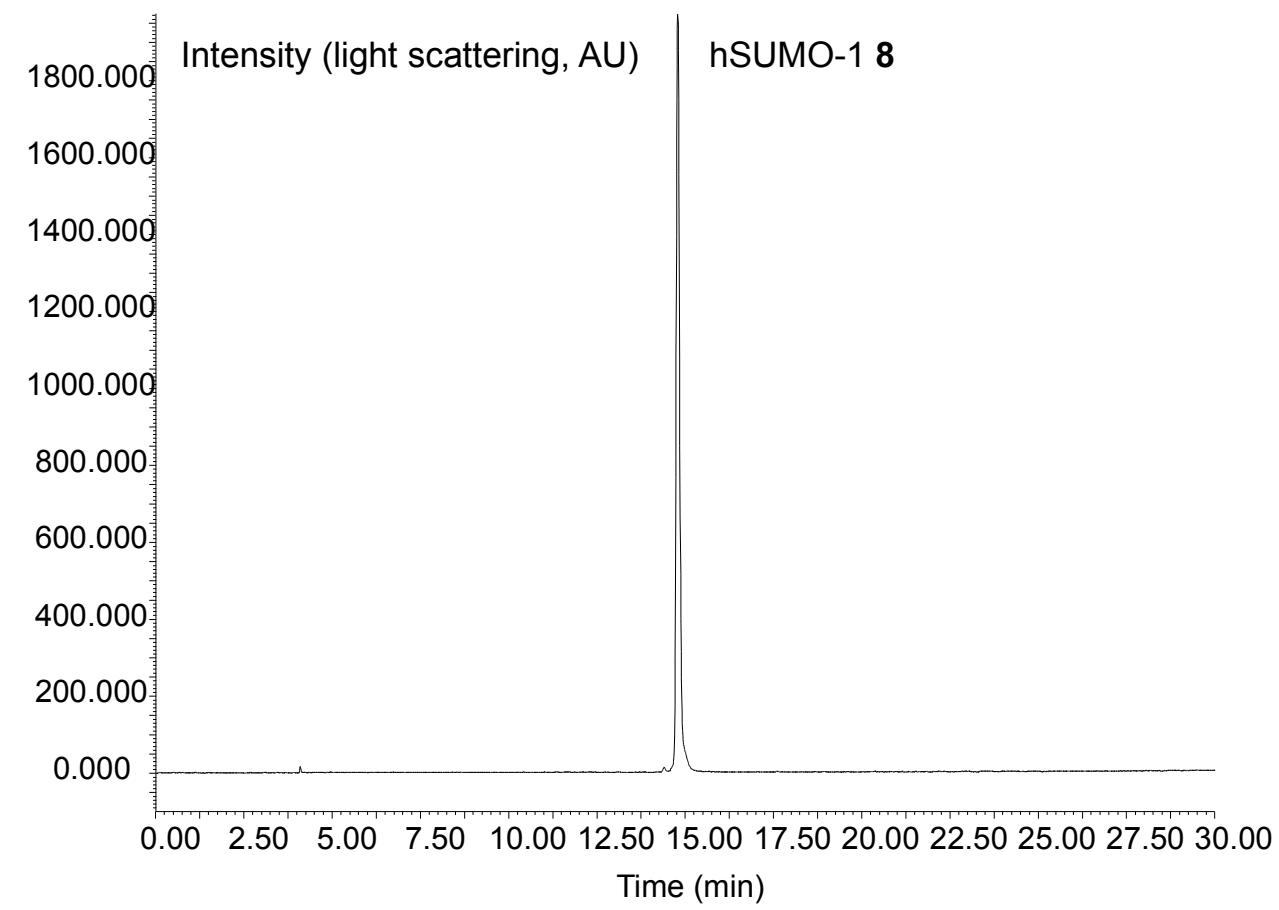

B)

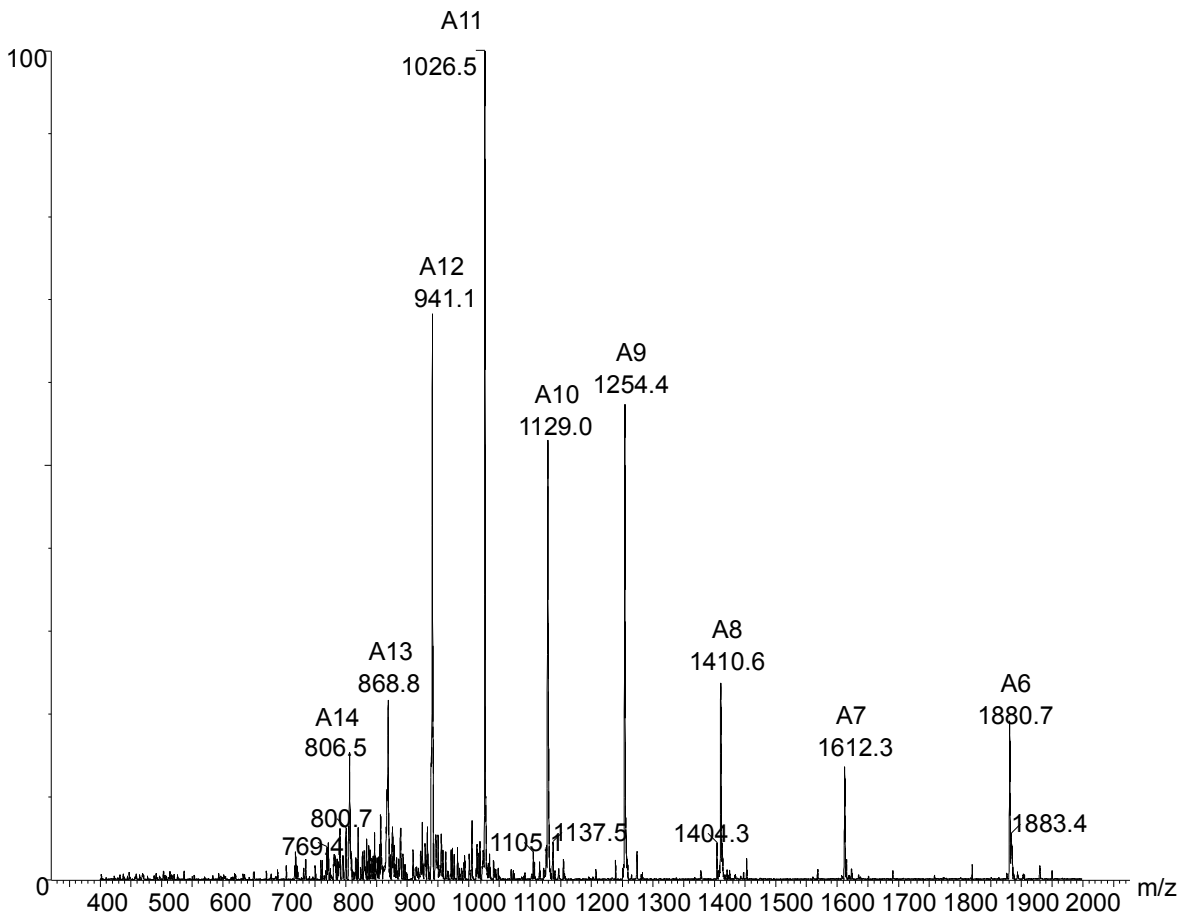


C)

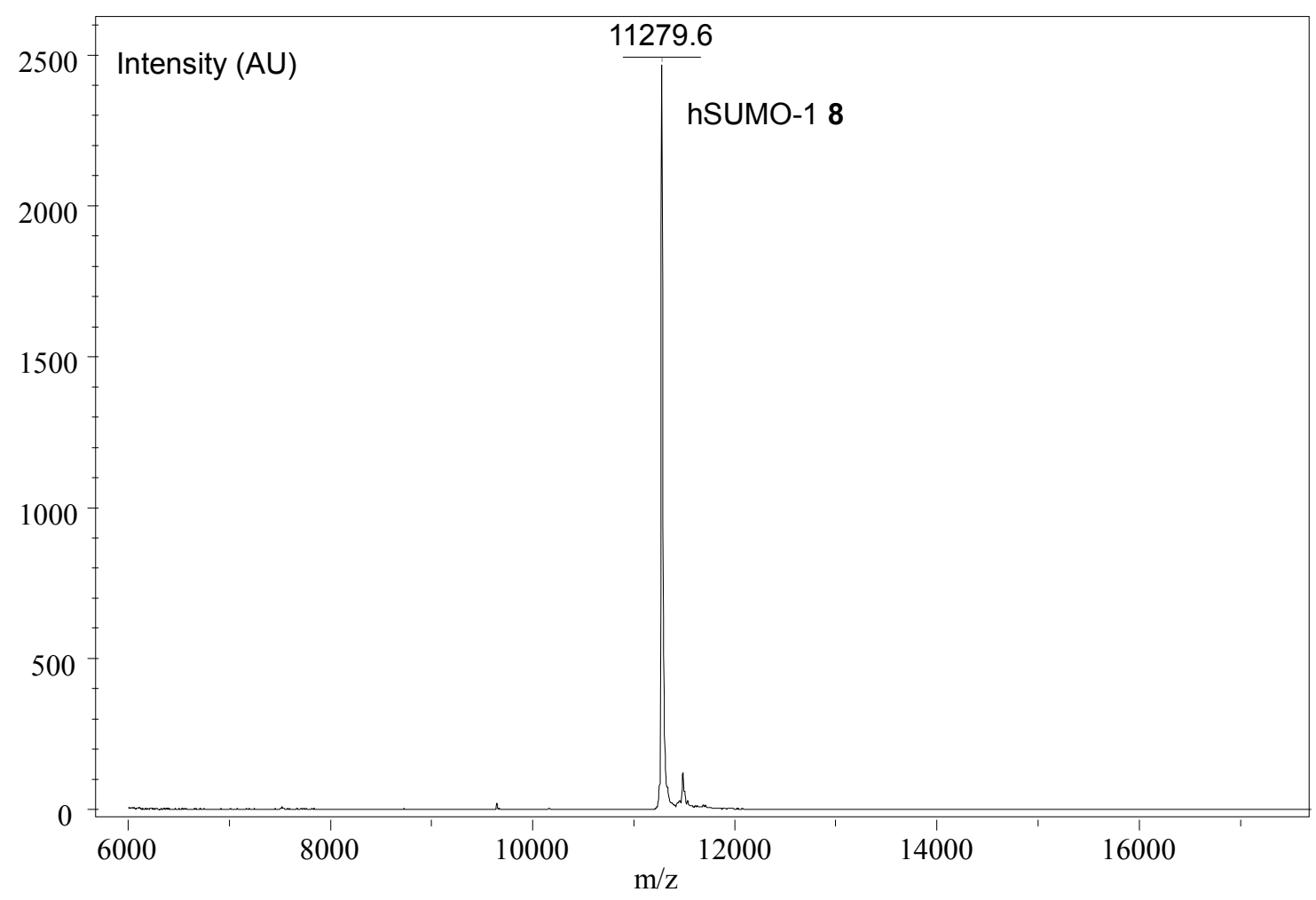

D)

11275.565
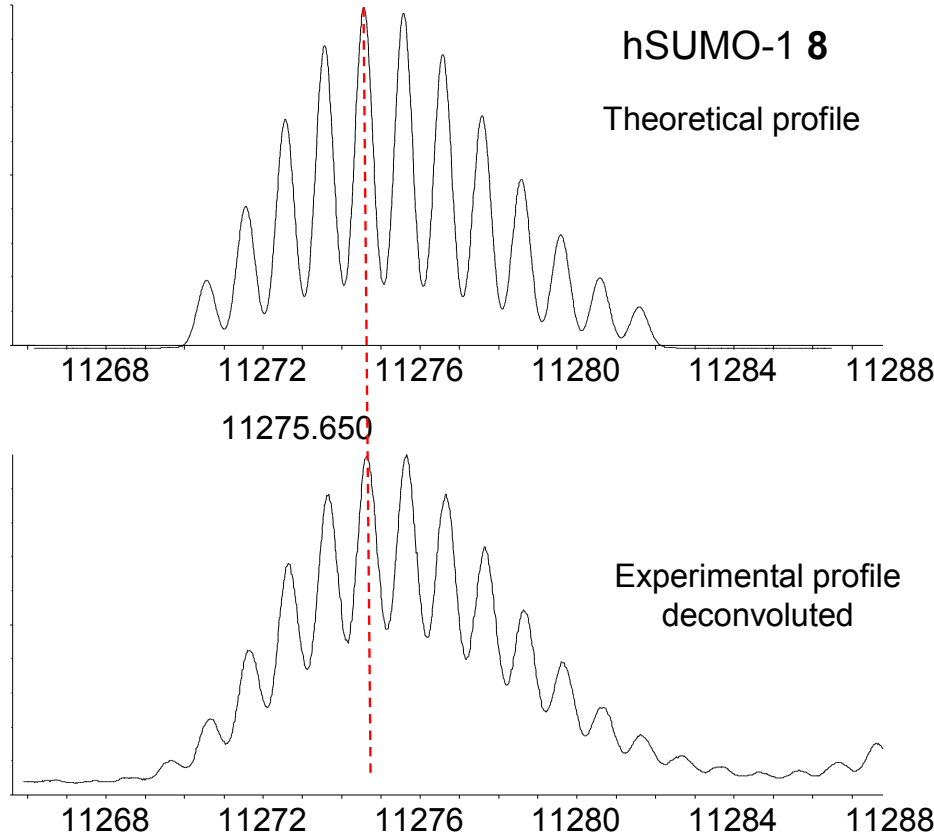

Fig. S24. Characterization of hSUMO-1 protein 8. A) LC trace from LC-MS analysis: C3 Zorbax column $(5 \mu \mathrm{m}, 300 \AA ̊ \Omega, 4.6 \mathrm{~mm} \times 150 \mathrm{~mm}), 50{ }^{\circ} \mathrm{C}$. Flow $1 \mathrm{~mL} / \mathrm{min}$, eluent A $0.1 \%$ trifluoroacetic acid in water, 
eluent B $0.1 \%$ trifluoroacetic acid in $80 \%$ aqueous acetonitrile. Gradient from $0 \%$ buffer B to $100 \%$ buffer B in $30 \mathrm{~min}$. B) ESI MS trace from LC-MS analysis. Calculated [M] (average mass) 11276.6 observed $11279.56+$ /- 1.3. C) MALDI-TOF analysis using sinapinic acid as matrix. Calculated $[\mathrm{M}+\mathrm{H}]^{+}$ (average mass) 11277.6 observed 11279.6. D) HRMS analysis.

\section{Preparation of SUMO-1 C52A protein 9}

Recombinant SUMO-1 protein $(500 \mu \mathrm{g})$ was dissolved in $6 \mathrm{M} \mathrm{Gdn.HCl} 0.1 \mathrm{M} \mathrm{pH} 7.2$ ammonium phosphate buffer containing TCEP (200 mM final concentration), VA-044 (1.33 mM final concentration) and GSH (20 mM final concentration). The desulfurization was carried out at $37^{\circ} \mathrm{C}$ and monitored by MALDI-TOF mass spectrometry. After $10 \mathrm{~h}$, the sample was purified by RP-HPLC to yield $248 \mu \mathrm{g}(50 \%)$ of hSUMO-1 protein 9.

Preparative HPLC conditions: XBridge BEH300 C18 $(5 \mu \mathrm{m}, 300 \AA, 10 \times 300 \mathrm{~mm})$ column, eluent A water containing $0.1 \%$ of TFA, eluent $\mathrm{B} \mathrm{CH}_{3} \mathrm{CN} /$ water : $4 / 1$ by vol containing $0.1 \%$ of TFA, gradient: 0 $100 \% \mathrm{~B}$ in $10 \mathrm{~min}$, flow rate $6 \mathrm{~mL} / \mathrm{min}$, UV detection at $215 \mathrm{~nm}, 50^{\circ} \mathrm{C}$. The purified fractions were pooled, frozen at $-20^{\circ} \mathrm{C}$ and lyophilized.

A)

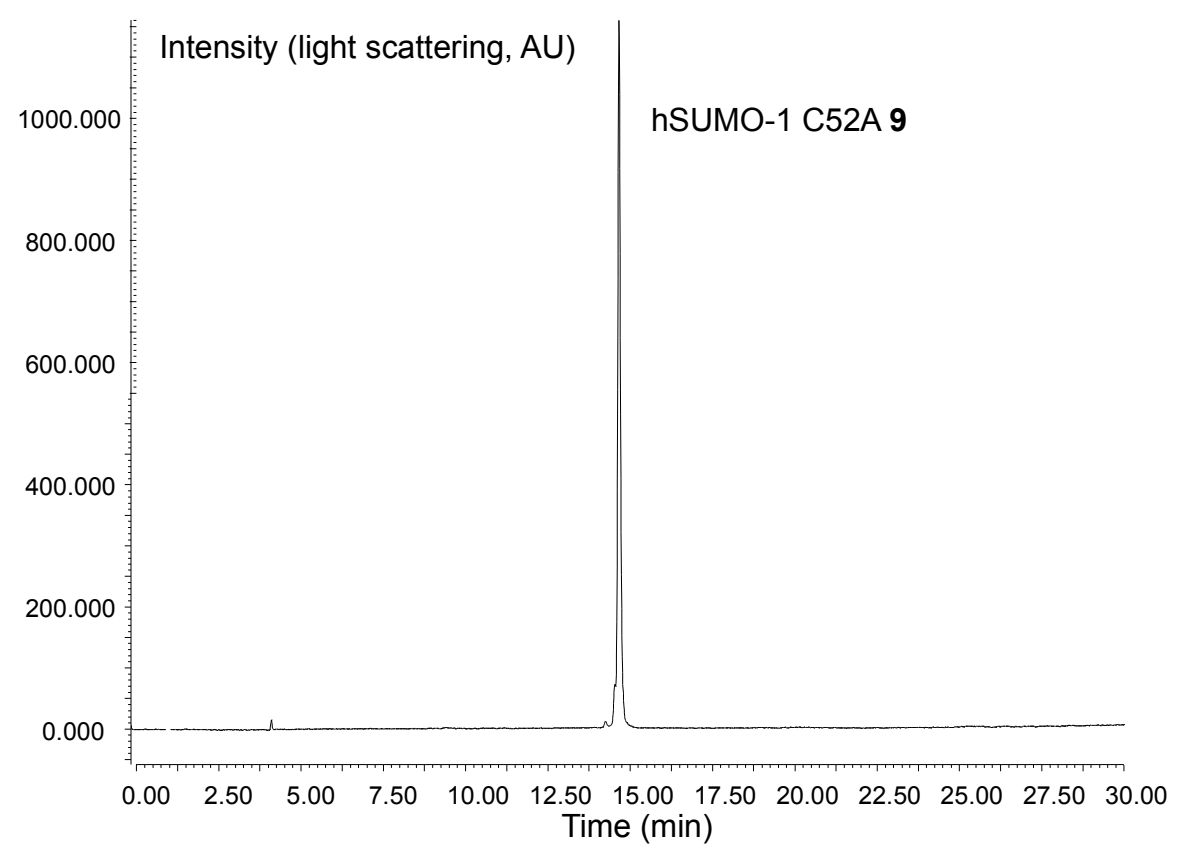


B)

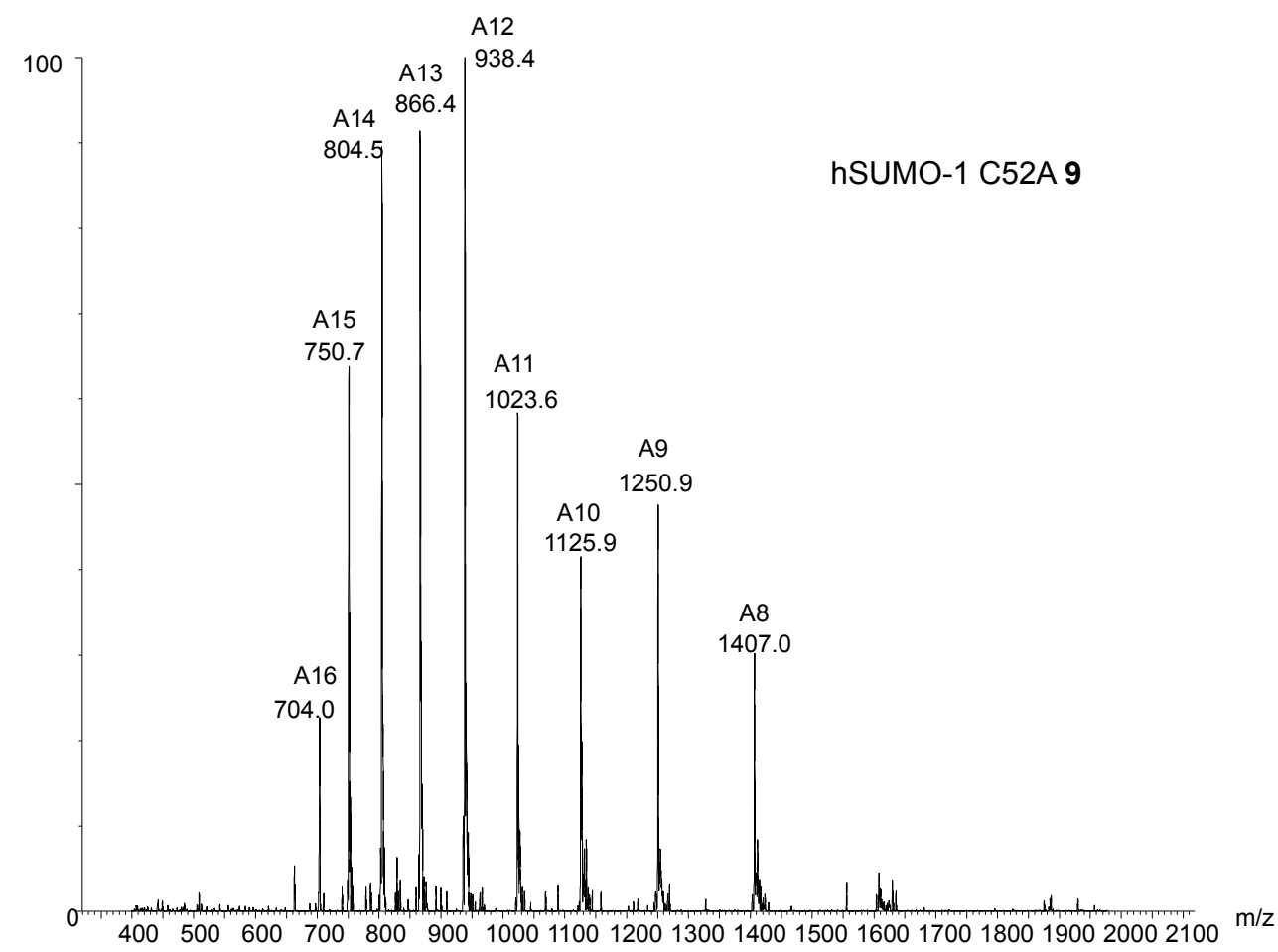

C)

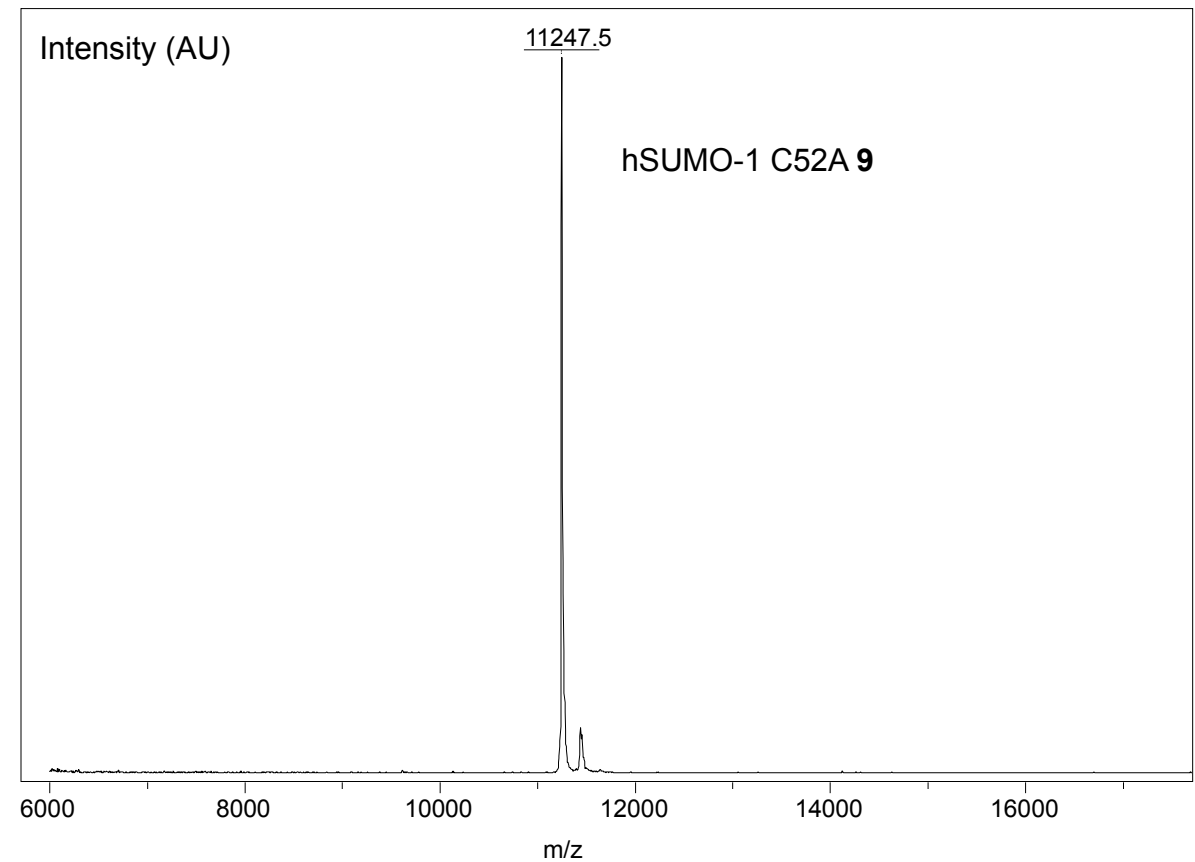


D)

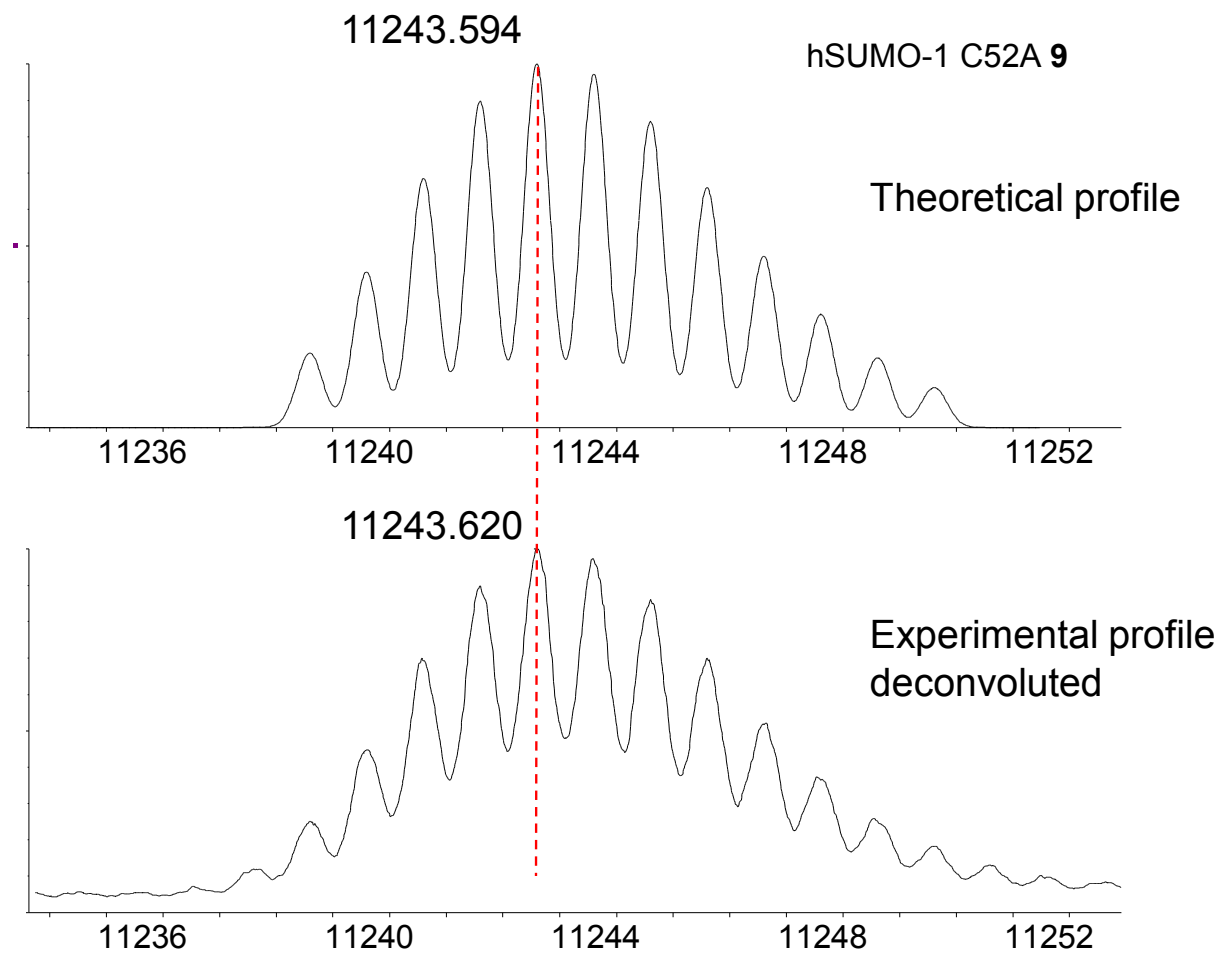

Fig. S25. Characterization of hSUMO-1 protein 9. A) LC trace from LC-MS analysis: C3 Zorbax column $(5 \mu \mathrm{m}, 300 \AA, 4.6 \mathrm{~mm} \times 150 \mathrm{~mm}), 50{ }^{\circ} \mathrm{C}$. Flow $1 \mathrm{~mL} / \mathrm{min}$, eluent $\mathrm{A} 0.1 \%$ trifluoroacetic acid in water, eluent B $0.1 \%$ trifluoroacetic acid in $80 \%$ aqueous acetonitrile. Gradient from $0 \%$ buffer B to $100 \%$ buffer B in $30 \mathrm{~min} . \mathrm{B}$ ) ESI MS trace from LC-MS analysis. Calculated [M] (average mass) 11244.6, observed $11248.3+$ /- 1.5. C) MALDI-TOF analysis using sinapinic acid as matrix. Calculated $[\mathrm{M}+\mathrm{H}]^{+}$ (average mass) 11245.6, observed 11247.6. D) HRMS analysis.

\section{Structure and functionality of p53 SUMO-1 conjugates}

\section{Thermal shift assay (TSA)}

The principle of the TSA assay used to monitor protein unfolding is based on the increase of the Sypro orange fluorescence by its binding to the hydrophobic regions of the protein, which become exposed to the dye upon protein unfolding.

The assay was optimized to reach the best fluorescence signal to noise ratio. Typical assay volumes were $20 \mu \mathrm{L}$ per well in 96-well PCR plate (Corning, US). The protein solutions $(0.15 \mathrm{mg} / \mathrm{mL}$ in deionized water) were mixed with the Sypro Orange dye $(2.5 \mu \mathrm{L}$ of a $20 \mathrm{X}$ solution prepared by diluting the 1000X dye solution with deionized water, Protein Thermal Shift ${ }^{\mathrm{TM}}$ kit, Life technologies, US) and the kit buffer $(5 \mu \mathrm{L})$. The plates were sealed with strips caps (Corning) and centrifuged at $1000 \mathrm{rpm}$ for $1 \mathrm{~min}$ to remove possible air bubbles. 
The thermal shift assay was performed in a Stratagene Mx3005p qPCR System (Agilent Technologies,

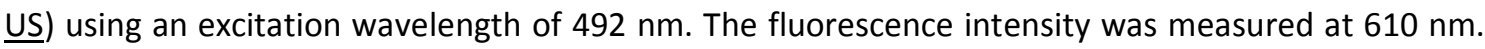
The thermal denaturation was performed by heating the plates from 25 to $95^{\circ} \mathrm{C}$ with stepwise increments of $1^{\circ} \mathrm{C}$ per min.

The data were analyzed as described by Niesen and coworkers by assuming a two-state transition model.(5) In brief, the raw fluorescence Ex492/Em610 values were analyzed using the MS Excel tool "DSF analysis" downloaded from ftp//ftp.ox.uk/pub/biophysics. Then, the data were fitted to a Boltzmann equation using Prism software to extract the $T_{m}$ values.

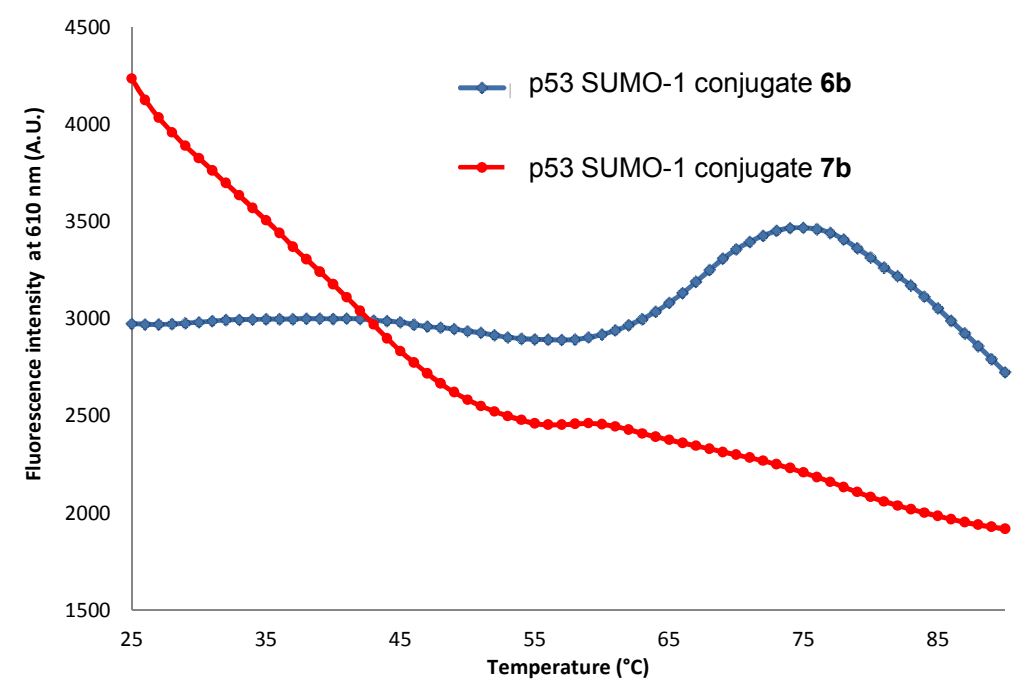

Fig S26. TSA analysis of p53 SUMO-1 conjugates $\mathbf{6 b}$ and $\mathbf{7 b}$ using Sypro orange dye. The dye was excited at $492 \mathrm{~nm}$ and the fluorescence intensity was measured at $610 \mathrm{~nm}$. The measured Tm for $\mathbf{6 b}$ $64.4 \pm 1.9^{\circ} \mathrm{C}$ is a mean of three independent experiments. No Tm could be calculated for p53 SUMO-1 conjugate $\mathbf{7 b}$. 


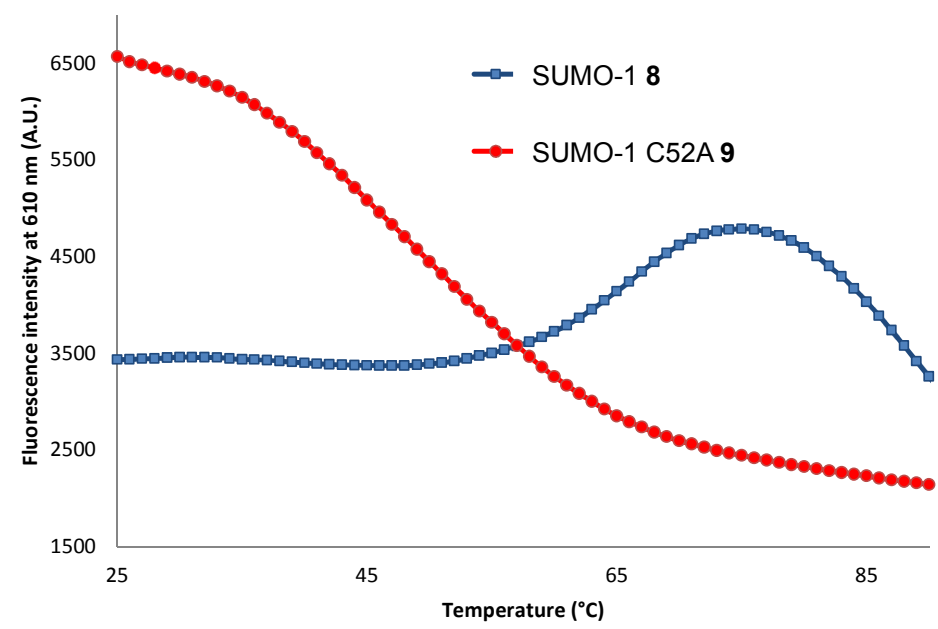

Fig S27. TSA analysis of recombinant SUMO-1 protein 8 and of the desulfurized analog (C52A) 9 using Sypro orange dye. The dye was excited at $492 \mathrm{~nm}$ and the fluorescence intensity was measured at $610 \mathrm{~nm}$. The measured Tm for recombinant SUMO-1 protein $865.9 \pm 1.2{ }^{\circ} \mathrm{C}$ is a mean of ten independent experiments. No Tm could be calculated for p53 SUMO-1 conjugate $\mathbf{7 b}$.

\section{Circular dichroism (Fig. 4)}

The concentration of SUMO-1 conjugates and recombinant SUMO-1 proteins solubilized in water were determined by measuring the absorbance at $280 \mathrm{~nm}$ and validated with BCA assay (Thermo) using BSA as a reference. The SUMO-1 conjugates and recombinant SUMO-1 proteins (stock solutions in water ranging from 1.1 to $1.3 \mathrm{mg} / \mathrm{mL}$ ) were diluted with sodium phosphate buffer (10 mM, pH 7.2) to a final concentration of $10 \mu \mathrm{M}$ for analysis.

The circular dichroism spectrum of the protein was recorded on a Jasco Model J-810 spectropolarimeter. $C D$ spectra were measured at $20{ }^{\circ} \mathrm{C}$ over the range $260-185 \mathrm{~nm}$ using $0.1 \mathrm{~cm}$ path-length cell and averaging of 10 scans. A $1 \mathrm{~nm}$ bandwidth, $0.2 \mathrm{~nm}$ data pitch and $20 \mathrm{~nm} / \mathrm{min}$ scanning speed were used for spectral acquisition.

The $\alpha$-helical content of the proteins was estimated using the empirical equation of Green- field \& Fasman (Greenfield, N.; Fasman, G. D. Biochemistry 1969, 8, 4108.):

$$
\alpha \text {-helix }=\left([\theta]_{\text {MWR }} 222 \mathrm{~nm}-3000\right) /(-36,000-3000) \times 100 .
$$


A) SUMO-1 C52A 9, thermal denaturation monitored at $202 \mathrm{~nm}$

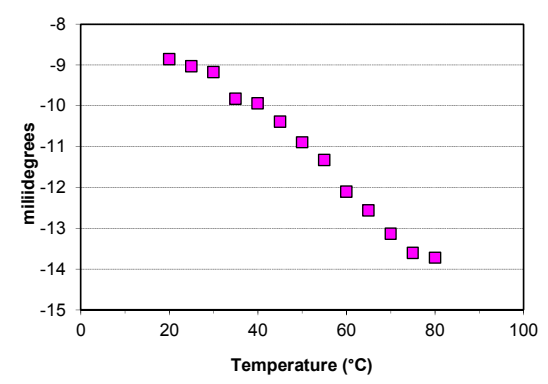

B) p53 SUMO-1 C52A 7b, thermal denaturation monitored at $202 \mathrm{~nm}$

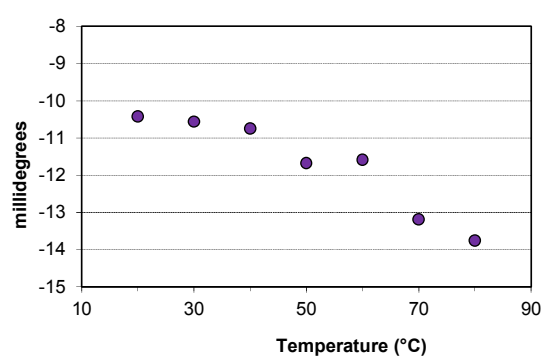

Fig S28. CD monitoring of the thermal denaturation of SUMO-1 Ala analog 9 or p53 SUMO-1 Ala analog $7 \mathrm{~b}\left(10 \mu \mathrm{M}, \mathrm{pH} 7.2,20-80^{\circ} \mathrm{C}\right)$.

\section{Cleavage of the p53 SUMO-1 conjugates $6 b$ and $7 b$ by Ulp1 enzyme \\ Monitoring by MALDI-TOF mass spectrometry}

10X SUMO protease buffer ( $0.5 \mu \mathrm{L}$, Invitrogen part number Y96063) was added to the conjugate (5 $\mu \mathrm{g}, 5 \mu \mathrm{L}$ of a solution at $1 \mathrm{mg} / \mathrm{mL}$ in LCMS-grade quality water). The final buffer composition was $50 \mathrm{mM}$ Tris- $\mathrm{HCl}$, pH 8, 0.2\% Igepal (NP-40), $1 \mathrm{mM}$ DTT.

The SUMO protease Ulp1 ( $1 \mu \mathrm{L}, 1$ unit $^{5}$ in $25 \mathrm{mM}$ Tris-HCl, pH 8.0, 0.1\% Igepal (NP-40), $250 \mathrm{mM} \mathrm{NaCl}$, $500 \mu \mathrm{M}$ DTT, $50 \%$ (v/v) glycerol) was added to the conjugate solution. The enzymatic reaction was performed at $25^{\circ} \mathrm{C}$ and monitored by MALDI-TOF mass spectrometry or SDS-PAGE.

The samples $(0.5 \mu \mathrm{L})$ for $\mathrm{MS}$ analysis were mixed with a solution of sinapic acid $(2 \mu \mathrm{L}, 15 \mathrm{mg} / \mathrm{mL}$ in acetonitrile/water : $1 / 1$ by vol containing $0.1 \%$ by vol of TFA) and allowed to dry on the MALDI plate at room temperature before analysis. 
A)

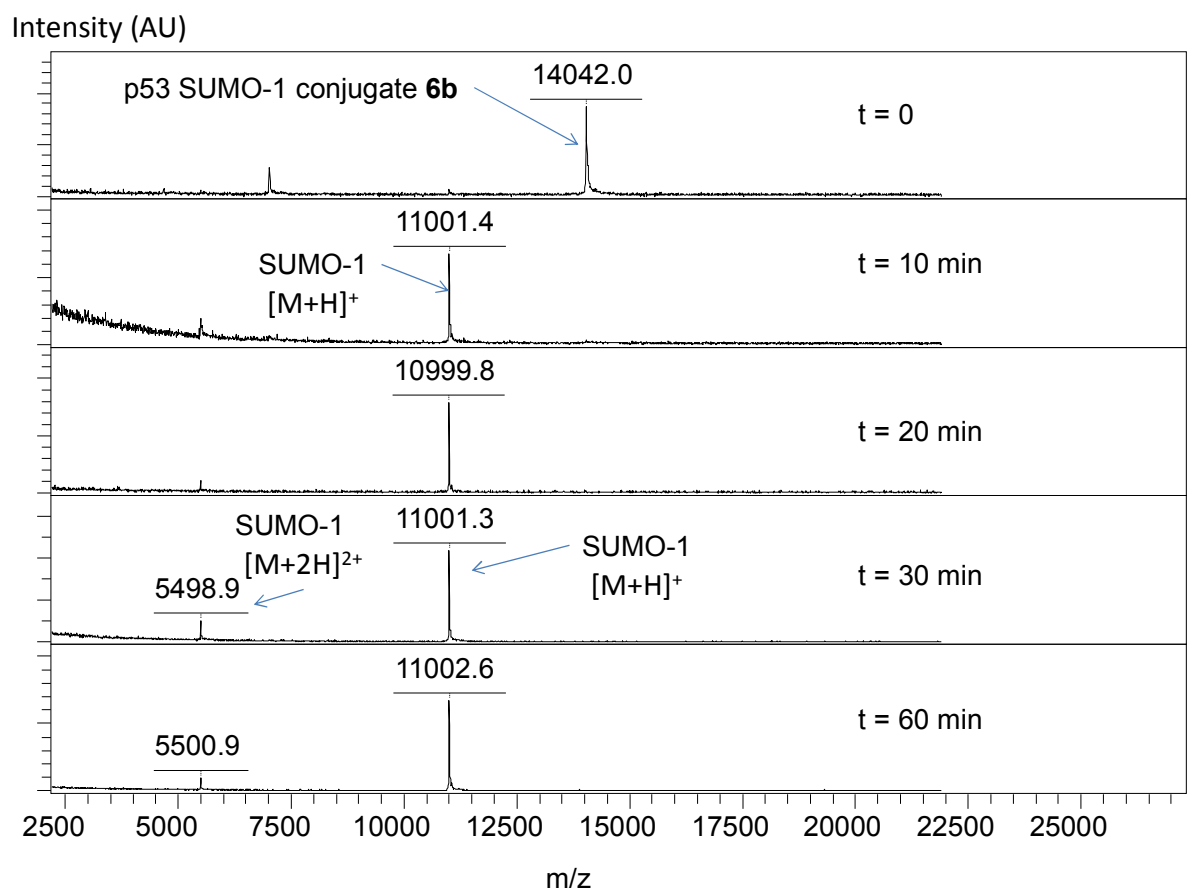

B)

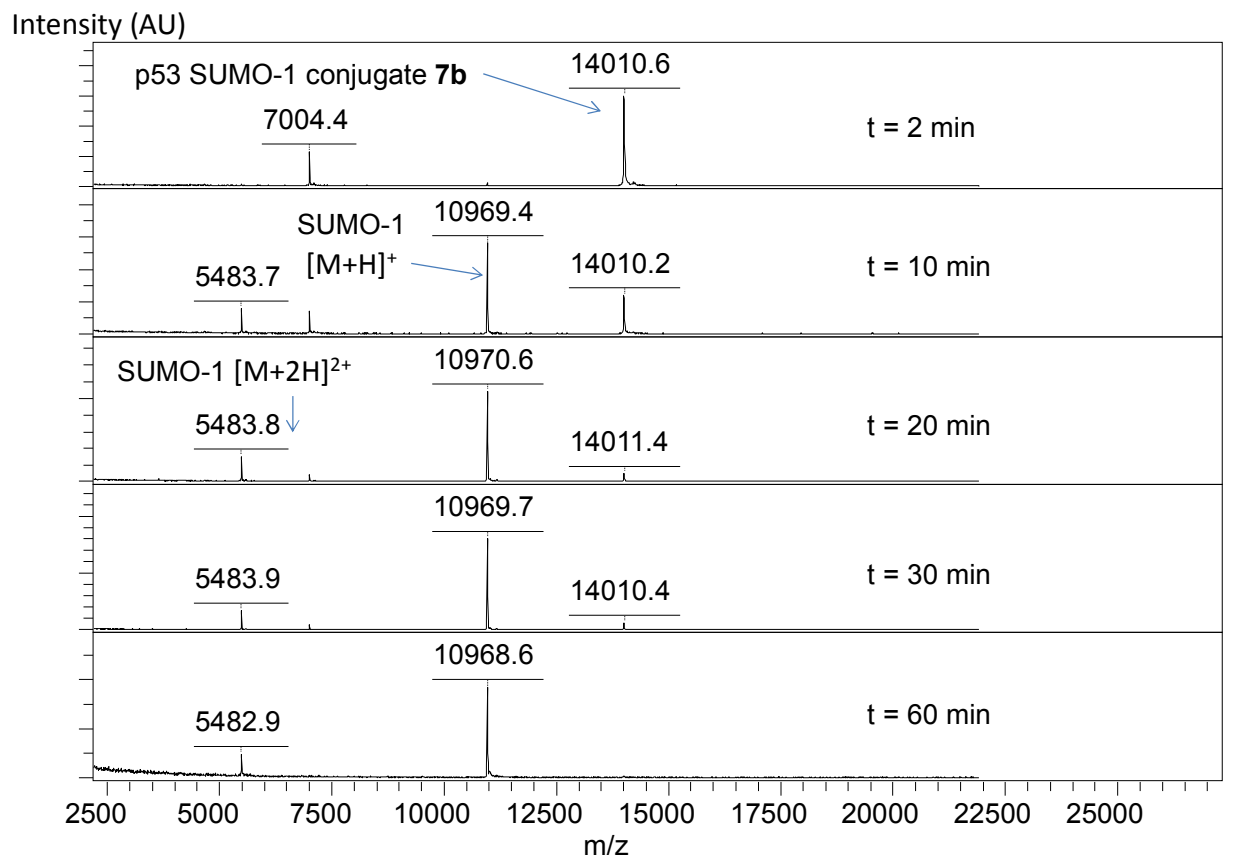

Figure S29. The desumoylation of conjugates $\mathbf{6 b}(\mathrm{A})$ and $\mathbf{7 b}$ (B) by Ulp1 enzyme at $37{ }^{\circ} \mathrm{C}$ was monitored by MALDI-TOF mass spectrometry (matrix: sinapinic acid). This experiment shows that the cleavage of the conjugates $\mathbf{6 b}$ was complete in less than $10 \mathrm{~min}$, while conjugate $\mathbf{7 b}$ was still detected after $30 \mathrm{~min} .[\mathrm{M}+\mathrm{H}]^{+}$calcd for SUMO-1 domain 11101.36 (average mass). 


\section{Monitoring by SDS-PAGE and Coomassie staining (Fig. 5A)}

p53-SUMO-1 conjugates $\mathbf{6 b}$ and $\mathbf{7 b}$ were diluted in $1 \mathrm{X}$ SUMO protease buffer to a $0.25 \mathrm{mg} / \mathrm{mL}$ concentration in a $20 \mu \mathrm{L}$ final volume and strictly kept on ice until addition of $1 \mu \mathrm{L}$ (1 unit) of Ulp1 protease. Mixtures were immediately splitted in $2 \mu \mathrm{L}$ aliquots and placed at $20^{\circ} \mathrm{C}$ or $37^{\circ} \mathrm{C}$. Enzymatic reactions was quenched after $0,2,5,10$ or $30 \mathrm{~min}$ by addition $40 \mu \mathrm{L}$ of LDS NuPage Sample Buffer (Invitrogen, NP0007) supplemented with $50 \mathrm{mM}$ DTT and $100 \mathrm{mM} \beta$-mercaptoethanol. Samples were heated at $70^{\circ} \mathrm{C}$ for $10 \mathrm{~min}$. Next, $20 \mu \mathrm{L}$ of each sample was loaded into a 4-12\% gradient NuPage Midi Gel (Invitrogen, WG1402A) and ran in a MES-SDS running buffer (Invitrogen, NP0002) at 150V for 1 h30.

The gel was fixed and stained in Coomassie solution $(40 \% \mathrm{MetOH}, 8 \%$ acetic acid, $0.01 \%$ Comassie R250, Sigma B-0149)) for $1 \mathrm{~h}$ and distained (20\% MetOH, $8 \%$ acetic acid) until obtaining crystal clear background.

\section{In vitro SUMOylation Assay (Fig. 5B)}

SUMOylation activity was performed using a commercially Sumoylation kit (Enzo Life Sciences, Farmingdale, NY) according to manufacturer procedure. Briefly, assays were performed in a $20 \mu \mathrm{L}$ final volume by adding in the following order: $2 \mu \mathrm{L}$ of 10X SUMOylation buffer stock solution, $1 \mu \mathrm{L}$ 20X ATP, $1 \mu \mathrm{L}$ of 20X E1 and $1 \mu \mathrm{L}$ of 20X E2 ligase, $2 \mu \mathrm{L}$ 20X RanGAP1 and $1 \mu \mathrm{L}$ of recombinant SUMO1 protein from Sumoylation kit (150 ng) or $2 \mu \mathrm{L}$ of SUMO-1 protein 8 or desulfurized SUMO-1 C52A analog 9 (150 ng). Negative controls were performed without ATP or SUMO-1 protein and the volume adjusted to $20 \mu \mathrm{L}$ with deionized water. Reaction mixtures were incubated at $37^{\circ} \mathrm{C}$ for 10,20 or $30 \mathrm{~min}$ and immediately quenched with $20 \mu \mathrm{L}$ of $2 \mathrm{X}$ LDS NuPage Sample Buffer (Invitrogen, NP0007) supplemented with $50 \mathrm{mM}$ DTT and $100 \mathrm{mM} \beta$-mercaptoethanol. As laoding and reference control $150 \mathrm{ng}$ of SUMO-1 proteins 8 and 9 were loaded in $20 \mu \mathrm{L}$ of 1X LDS buffer. After heating at $70^{\circ} \mathrm{C}$ for $5 \mathrm{~min}, 10 \mu \mathrm{L}$ of samples were analyzed by SDS-PAGE as described previously in "General protocol for SDS-PAGE and Coomassie staining" section and Western blotting was performed as proposed by the Sumoylation kit procedure using a 1/1000 anti-SUMO antibody and a 1/30000 antirabbit HRP conjugated secondary antibody dilution (Jackson Immunoresearch, \#711-035-152).

\section{References}

(1) Ollivier, N., Dheur, J., Mhidia, R., Blanpain, A., and Melnyk, O. (2010) Bis(2sulfanylethyl)amino native peptide ligation. Org. Lett. 12, 5238-41.

(2) Boll, E., Drobecq, H., Ollivier, N., Blanpain, A., Raibaut, L., Desmet, R., Vicogne, J., and Melnyk, O. (2015) One-pot chemical synthesis of small ubiquitin-like modifier (SUMO) proteinpeptide conjugates using bis(2-sulfanylethyl)amido peptide latent thioester surrogates $\mathrm{Nat}$. Protocols 10, 269-292.

(3) Boll, E., Drobecq, H., Ollivier, N., Raibaut, L., Desmet, R., Vicogne, J., and Melnyk, O. (2014) A novel PEG-based solid support enables the synthesis of $>50$ amino-acid peptide thioesters and the total synthesis of a functional SUMO-1 peptide conjugate. Chem. Sci. 5, 2017-2022. Haj-Yahya, M., Ajish Kumar, K. S., Erlich, L. A., and Brik, A. (2010) Protecting group variations of delta-mercaptolysine useful in chemical ubiquitylation. Biopolymers 94, 504-10. 
(5) Niesen, F. H., Berglund, H., and Vedadi, M. (2007) The use of differential scanning fluorimetry to detect ligand interactions that promote protein stability. Nat. Protocols 2, 2212-21. 